\title{
Income, Democracy, and Leader Turnover
}

\author{
Daniel Treisman*
}

April 2014

\begin{abstract}
While some believe that economic development prompts democratization, others contend that both result from distant historical causes. Using the most comprehensive estimates of national income available, I show that development is associated with more democratic governmentbut mostly in the medium run (10 to 20 years). This is because higher income tends to induce breakthroughs to more democratic politics only after an incumbent dictator leaves office. And in the short run, faster economic growth increases the ruler's survival odds. Leader turnover appears to matter because of selection: in authoritarian states reformist leaders tend to either democratize or lose power relatively quickly, so long-serving leaders are rarely reformers. Autocrats also become less activist after their first year in office. This logic helps explain why dictators, concerned only to prolong their rule, often inadvertently prepare their countries for jumps to democracy after they leave the scene.
\end{abstract}

Keywords: democracy, economic development, modernization, leadership JEL classifications: D78, I25, N10, O10

*Professor, Department of Political Science, University of California, Los Angeles, 4289 Bunche Hall, Los Angeles CA 90095, email: treisman@ polisci.ucla.edu and NBER.

I thank Yoram Barzel, Massimo Bordignon, Bruce Bueno de Mesquita, Carles Boix, Jim DeNardo, Daniel Diermeier, Georgy Egorov, Robert Fleck, Scott Gehlbach, Jack Goldstone, Guy Grossman, Phil Keefer, Ryan Kennedy, James Kung, Jeff Lewis, Ian Lustick, Eddy Malesky, Ed Mansfield, Jorge MartinezVazquez, Michael Miller, Carlo Prato, Jim Robinson, Andrei Shleifer, Rudra Sil, Alberto Simpser, Konstnantin Sonin, Jim Vreeland, Georgy Yegorov, and other participants in seminars at Northwestern University, Hong Kong University of Science and Technology, the IFO Institute, Dresden, the University of Chicago, the University of Pennsylvania, the ISNIE annual conference 2012, and the International Institute of Public Finance Annual Meeting 2013 for valuable comments and suggestions, and the UCLA College of Letters and Sciences for support. 
Under Generalisimo Franco, Spain metamorphosed from a rural backwater into the world's eleventh largest industrial economy. ${ }^{1}$ Between 1939, when Franco seized power, and 1975, when he died of old age, GDP per capita quadrupled, the flow of passengers through Spanish airports rose from 81,000 to 38 million a year, and the number of telephones increased from 295,000 to 7.8 million (Carreras and Tafunell 2005). ${ }^{2}$ Despite growing demands for political liberalization, the regime remained a brutal and arbitrary despotism. Yet just a few years after Franco's death, Spain had shot to the top of democracy ratings.

Spain's experience illustrates why the notion that economic development prompts democratization—although largely correct—remains controversial. A vast literature asserts this relationship. ${ }^{3}$ Yet whenever consensus seems to be forming, influential critics point out exceptions and advance alternative theories. ${ }^{4}$ Looking at Spain, one sees why this debate refuses to die. On one hand, historians are "in general agreement that the ultimate reason [for the late 1970s breakthrough] lay in... the rapid and radical process of socioeconomic development that took place in the 1960s" (Casanova 1983, p.935). Urbanization, unionization, trade, expanding information flows, and pressures from a burgeoning business community all contributed. Yet for years under Franco Spain seemed a clear counterexample to any version of modernization theory. Then from the early $1980 \mathrm{~s}$

\footnotetext{
${ }^{1}$ The data and other replication materials for this paper are posted at http://thedata.harvard.edu/dvn/faces/study/StudyPage.xhtml?tab=files\&vdcId=1410\&studyId=92586\&versionNumber= 1 . An appendix containing various technical materials, robustness checks, extensions, and data notes is available on the AJPS site.

${ }^{2}$ Whether Franco's policies promoted or delayed this development is debated (see, for instance, Prados de la Escosura et al. 2010); at least he did not prevent it.

${ }^{3}$ Lipset (1959) is the classic reference. For recent treatments: Barro (1999), Boix and Stokes (2003), Epstein et al. (2006), Glaeser et al. (2004), Glaeser, Ponzetto, and Shleifer (2007), Inglehart and Welzel (2005).

${ }^{4}$ For instance, O’Donnell (1988), and most recently Przeworksi et al. (2000) and Acemoglu, Johnson, Robinson, and Yared (AJRY) (2005, 2008, 2009).
} 
it became anomalous again: having reached a perfect score on democracy ratings, it could rise no higher despite continued development.

In this paper, I suggest a way to reconcile the two sides of this debate, while integrating the "structural" and "agency" views, which attribute democratization, respectively, to underlying conditions and contingent actions. The key linking element is leader turnover, which activates previously dormant effects of development. Rising income does not translate smoothly into incremental increases in democracy. Under a dictator like Franco, modernization can proceed for years without political reform. However, the resulting gap between the country's development level and its politics fuels a breakthrough after the leader exits. Structural factors such as development matter — but primarily during periods of succession, when the strategic environment and leaders' choices interact with underlying conditions to shape outcomes.

Why does leader turnover matter? First and foremost, because leaders do. Recent research has explored how authoritarian rulers are constrained by elected legislatures, party organizations, and their own selectorates (e.g. Gandhi and Przeworski 2007, Svolik 2012, Bueno de Mesquita et al. 2003). Important as such factors are, one cannot understand dictatorship without understanding dictators. Autocrats vary in the resources, skills, and preferences they bring to the mission of clinging to power. As authoritarian states develop, the distribution of incoming leaders comes to include some who-because of education or modern values - permit reform. Over time, reformers are selected out as they introduce and lose elections or are ousted by coups. ${ }^{5}$ The survivors tend to be determined and skillful reactionaries, often governing subtypes of autocracy resistant to liberalization. Still, even after accounting for such selection, reformers reform more in their first year than later. This could result from greater factional competition early on or a change in the

\footnotetext{
${ }^{5}$ Their countries also fall out of the nondemocracies data when they cross the democracy threshold.
} 
leader's thinking as he consolidates. Either way, the slowdown in democratization fits a more general pattern of declining activism: in later years, dictators are also less prone to increase repression, amend the constitution, or initiate military conflict.

This helps explain a number of additional facts. First, economic development has different consequences in the short and medium run. In the medium run (10-20 years), higher income predicts political liberalization; in the short run, no general relationship holds. ${ }^{6}$ In part, this is because the odds of leader exit rise as the time window lengthens. Second, the political effect of the level of development (or income) differs from that of change in that level (or growth). Higher income - eventually—promotes political liberalization. By contrast, faster growth, even though it raises the income level, does not. That is because faster growth also entrenches incumbent leaders, whether dictators or democrats, helping autocrats resist pressures for reform. Thus, low growthespecially in countries with high income — might be thought to foster democratization.

Third, however, poor economic performance is not usually enough to prompt reform even in developed autocracies. Liberalization results when economic crisis—or some other event—unseats the top leader. After leader turnover, the odds of a rich country liberalizing shoot up, while those for poor countries remain low. Economic downturns without leader exit do not lead to liberalization.

To show that Spain's experience is not unusual, Table 1 lists the 21 dictators under whom per capita income rose above $\$ 6,000 .^{7}$ While in power, most either froze or reduced their country's democracy level. But in 16 of 21 cases, the decade after the leader's exit saw—often dramatic-

\footnotetext{
${ }^{6}$ By "political liberalization"—or just "liberalization,"-I mean movement towards democracy that does not necessarily reach a high level of it.

${ }^{7}$ In 1990 international dollars; a similar picture, slightly less pronounced, obtains using $\$ 5,000$ or $\$ 7,000$.
} 
liberalization. Not all made huge leaps. ${ }^{8}$ But the average Polity 2 increase 10 years after the dictator left, +8.1 on a 21 -point scale, far exceeds the average for nondemocracies, +1.1 .

The logic outlined here suggests a dilemma for autocrats. Most wish both to survive in power and to institutionalize their rule. Supporting economic growth increases their personal survival odds. But the higher development level it produces over time makes it harder to deliver the state to a son or trusted aide. While prolonging their own tenure, they unintentionally hasten their regime's demise.

Two other recent papers suggest income has a conditional effect on democratization. They disagree about what triggers the relationship. For Kennedy (2010), the key is low growth, which prompts major institutional change that takes a democratic form in more developed countries. Miller (2012) argues that what activates the income-democracy link is fragility of the state, which is revealed by violent leader replacement. In line with Kennedy, I show that economic downturns can prompt liberalization in richer states—but only if they cause leader turnover, a factor Kennedy does not explore. Low growth without leader change is not associated with political reform. Contra Miller, I find that it is leader change itself, not underlying fragility of the state, that prompts liberalization in richer autocracies. Other measures of state weakness examined here do not appear to activate the income effect. Moreover, peaceful, regular leader replacement has a stronger impact than violent turnover. ${ }^{9}$ What matters is the replacement of hardened reactionaries by leaders readier to reform, not the condition of the state or the violence of the turnover. A third paper (Jones and

\footnotetext{
${ }^{8}$ Venezuela jumped 9 points in the $11^{\text {th }}$ year. Civil-war-torn Yugoslavia democratized after 20. Chile had already recorded a 14-point surge in Pinochet's last years. Oil-rich Libya and Saudi Arabia experienced no breakthroughs. South Korea, Taiwan, and Mexico liberalized under the dictators in the table (all within 10 years of the previous leader's exit and at income above $\$ 4,000)$.

${ }^{9}$ Unlike Miller, I also examine why leader turnover matters. Neither Kennedy nor Miller considers the divergent effects of income on democracy in the short and medium run or the dilemma for dictators created by the different impact of income levels and rates of growth.
} 
Olken 2009) analyzes how assassination of dictators affects political institutions and military conflict, but does not explore the impact of income on democratization.

\section{Table 1: Dictators under whom GDP per capita rose above $\$ 6,000,1875-2004$}

\begin{tabular}{|c|c|c|c|c|}
\hline Leader & Country & Tenure & $\begin{array}{l}\text { Change in Polity } 2 \\
\text { under dictator }\end{array}$ & $\begin{array}{l}\text { Change in Polity } 2 \\
\text { in decade after } \\
\text { dictator's exit }\end{array}$ \\
\hline Hitler & Germany & 1933-1945 & -15 & +19 \\
\hline Mendez & Uruguay & 1976-1981 & +1 & +17 \\
\hline Franco & Spain & $1939-1975$ & -14 & +17 \\
\hline Kadar & Hungary & 1956-1988 & 0 & +17 \\
\hline Husak & Czechoslovakia & 1968-1989 & 0 & $+15.5^{\mathrm{b}}$ \\
\hline Papadopoulos & Greece & $1967-1973$ & -11 & +15 \\
\hline Zhivkov & Bulgaria & 1956-1989 & 0 & +15 \\
\hline Caetano & Portugal & 1968-1974 & 0 & +13 \\
\hline Chiang Ching-Kuo & Taiwan & 1978-1988 & +6 & +10 \\
\hline Illia & Argentina & 1963-1966 & 0 & +7 \\
\hline Brezhnev & USSR & 1964-1982 & 0 & +7 \\
\hline Chun & South Korea & 1980-1988 & +9 & +5 \\
\hline Salinas & Mexico & 1988-1994 & +3 & +4 \\
\hline Lopez Portillo & Mexico & 1976-1982 & +3 & +3 \\
\hline Mahatir & Malaysia & $1981-2003$ & -1 & $+3^{\mathrm{a}}$ \\
\hline Al-Assad & Syria & $1971-2000$ & 0 & +2 \\
\hline Betancourt & Venezuela & 1945-1948 & 0 & 0 \\
\hline Mijatovic & Yugoslavia & $1980-1981$ & +2 & 0 \\
\hline Idris & Libya & 1951-1969 & 0 & 0 \\
\hline Faisal & Saudi Arabia & 1964-1975 & 0 & 0 \\
\hline Pinochet & Chile & 1973-1990 & +2 & 0 \\
\hline Mean & & & -0.7 & +8.1 \\
\hline
\end{tabular}

Sources: see Table A18 in online Appendix.

Note: Table lists all leaders out of office by 2004 in whose first year Polity $2<6$ and under whom per capita GDP rose above $\$ 6,000$. "Change in Polity2 under dictator": on 21-point scale, from beginning of leader's entry year to end of last full year in office. "Change in Polity2 in decade after dictator's exit": from end of last full year in office to 10 years later, or if Polity 2 changed during turnover year before or simultaneously with the leader exit, from the end of turnover year to 10 years later. ${ }^{a}$ next 8 years, to end of data. ${ }^{b}$ average for Czech and Slovak Republics.

The article is structured as follows. The next section reexamines the relationship between income and democracy, showing it is stronger in the medium than short run and that income matters 
more after leader exit. The following section checks robustness and identification. I then examine why the effect of development depends on leader turnover. The final section concludes.

\section{Development, democracy, and leader change}

Here, I show there is a clear relationship between income and democracy, but that it is stronger in the medium than short run, and much stronger shortly after leader turnover. For national income, I use the latest estimates of Maddison and collaborators (Maddison 2010). ${ }^{10}$ The main dependent variable is the Polity2 index (Polity IV dataset, 2009 version), rescaled to range from 0 (pure autocracy) to 1 (pure democracy). This measures the openness and competitiveness of political participation and executive recruitment, along with constraints on the executive. Besides this indicator of the level of democracy, I show regressions in the appendix for two measures of transitions to democracy, one using a dichotomous variable constructed by Boix, Miller, and Rosato (2013), the other capturing just upward Polity2 movements.

To explore how medium and short run effects differ, I constructed panels at different frequencies - annual, 5-year, 10-year, 15-year, and 20-year. As in AJRY (2008, 2009) and Boix (2011), the panels contain observations from every fifth year for the five-year panel, and so on, starting in 1820. Also following AJRY $(2008,2009)$ and Boix (2011), regressions include the lagged dependent variable to capture persistence in democracy, reduce serial correlation, and pick up any tendency to revert to the mean. Where relevant, I calculate the cumulative effect. ${ }^{11}$

\footnotetext{
${ }^{10}$ Following Boix (2011), I interpolate linearly to fill gaps in early years, increasing observations by up to 28 percent. Results are similar dropping interpolations (Appendix Tables A1, A2).

${ }^{11}$ In a model with lagged dependent variable: $d_{i t}=\alpha d_{i t-1}+\gamma y_{i t-1}$, the cumulative effect of income is $\gamma /(1-\alpha)$. For more complicated models, see Appendix p.1. This measures the total effect of a one unit change in income, incorporating the indirect effects in future periods running through the lagged dependent variable. Since, for any panel, this measures the total impact over all future periods, estimates are comparable across panel frequencies.
} 
My basic model is identical to that in AJRY (2008):

$$
d_{i t}=\alpha d_{i t-1}+\gamma y_{i t-1}+\mathbf{x}_{\mathbf{i t}-1}^{\prime} \mathbf{\beta}+\mu_{t}+\delta_{i}+u_{i t}
$$

where $d_{i t}$ is Polity2 in country $i$ in period $t ; y_{i t-1}$ is the natural log of per capita GDP in $i$ in the previous panel period; $\mathbf{x}_{\mathrm{it}-1}$ is a vector of covariates, lagged one period; $\mu_{t}$ is a full set of period dummies; $\delta_{i}$ a full set of country dummies; and $u_{i t}$ a random error with $E\left(u_{i t}\right)=0, \forall i, t$. (Note that throughout the paper $t$ refers to panel period rather than year.) I calculate robust standard errors clustered by country, and test regression residuals using a Fisher test for nonstationarity in panels. It almost always rejects nonstationarity, suggesting results do not merely capture parallel trends in income and democracy.

I focus on this model for several reasons (and show alternatives in the appendix). First, AJRY $(2008,2009)$ argue persuasively that including country and year fixed effects to capture unobserved heterogeneity and common shocks is vital given the strong time dependence in democratization and large differences in country characteristics. Even in democracy regressions with numerous controls, country and year fixed effects prove highly significant; omitting them risks serious bias. Second, since AJRY claim that, including country fixed effects, income no longer correlates with democracy, it is appropriate to use their model when questioning their conclusions.

Table 2, panel A, estimates this model for 1960-2000. As in AJRY $(2008,2009)$, income is insignificant with cumulative impact close to zero. This is true at all panel frequencies. Panel B includes all observations from 1820 (the first year with income data) to 2008. I also restrict attention to countries that start the given panel period as nondemocracies (i.e., Polity $2<6$ in the previous period; the Polity team treats +6 as democracy's lower bound). This is important for two reasons. First, the factors that promote democratization may differ from those that sustain democracy (Rustow 1970, Przeworski et al. 2000). It makes sense to analyze democracies and authoritarian 
states separately, and I focus here on what causes nondemocracies to liberalize. Second, besides theoretical concerns, there is a practical problem in using the full Polity 2 scale as dependent variable. Countries that reach a perfect $10-18$ percent during the $20^{\text {th }}$ century-cannot rise higher, however much they modernize. Not adjusting for censoring at the top risks biasing estimates of income's influence downwards (Benhabib et al. 2011). Now a new pattern emerges: in the 10-, 15-, and 20-year panels, income is significantly positive. The cumulative effect rises as panel frequency falls, reaching .25 for 20-year data.

Table A1 shows results are similar if one: drops interpolated income data (panel A); uses transitions to democracy rather than levels (panels B and C); excludes just perfect democracies (those for which Polity $\left.2_{\mathrm{t}-1}=10\right)($ panel D); uses the estimator of Alan, Honoré, and Leth-Petersen (2008), which allows for censoring at top and bottom while controlling for unobserved heterogeneity, as in Benhabib et al. (2011) (Panel E); and uses Arellano and Bond's dynamic GMM estimator (panel F). ${ }^{12}$ These checks reinforce the finding. If one extends data before 1945, and especially if one focuses on nondemocracies and adjusts for censoring, higher income correlates significantly with political liberalization. In failing to detect a relationship in annual data—and sometimes five-year panels - these results echo AJRY (2008, 2009). In finding one in lower frequency panels, they match Boix (2011) and Benhabib et al. (2011).

\footnotetext{
12 Although the significant coefficients using Arellano-Bond are reassuring, one might not necessarily expect a significant result. The Arellano-Bond model estimates relationships between levels from a regression of first differences, using past levels as instruments. I argue here precisely that short-run changes in income have different effects than long run levels.
} 
Table 2: Development, democracy, and leader change

\begin{tabular}{|c|c|c|c|c|c|c|c|c|c|c|c|c|c|c|c|c|}
\hline & \multicolumn{5}{|c|}{ (A) 1960-2000, all countries } & \multicolumn{5}{|c|}{ (B) $1820-2008$, Polity $2_{t-1}<6$} & \multicolumn{5}{|c|}{ (C) $1875-2004$, Polity $_{t-1}<6$} & \multirow[b]{2}{*}{$10-y r$} \\
\hline & $1-y r$ & $5-y r$ & $10-y r$ & $15-y r$ & $20-y r$ & $1-y r$ & $5-y r$ & $10-y r$ & $15-y r$ & $20-y r$ & $1-y r$ & $5-y r$ & $10-y r$ & $15-y r$ & $20-y r$ & \\
\hline & $(1)$ & $(2)$ & (3) & $(4)$ & $(5)$ & $(6)$ & $(7)$ & $(8)$ & (9) & $(10)$ & $(11)$ & $(12)$ & $(13)$ & $(14)$ & $(15)$ & $(16)$ \\
\hline Polity $2 \mathrm{t}-1$ & $\begin{array}{l}.88 * * * \\
(.01)\end{array}$ & $\begin{array}{l}.47 * * * \\
(.05)\end{array}$ & $\begin{array}{l}.15^{*} \\
(.09)\end{array}$ & $\begin{array}{l}-.03 \\
(.10)\end{array}$ & $\begin{array}{l}-.17 * \\
(.09)\end{array}$ & $\begin{array}{l}.92 * * * \\
(.01)\end{array}$ & $\begin{array}{l}.62 * * * \\
(.06)\end{array}$ & $\begin{array}{l}.29 * * * \\
(.09)\end{array}$ & $\begin{array}{l}.27 * * \\
(.12)\end{array}$ & $\begin{array}{l}.10 \\
(.10)\end{array}$ & $\begin{array}{l}.91 * * * \\
(.01)\end{array}$ & $\begin{array}{l}.53 * * * \\
(.07)\end{array}$ & $\begin{array}{l}.16^{*} \\
(.10)\end{array}$ & $\begin{array}{l}.12 \\
(.14)\end{array}$ & $\begin{array}{l}-.01 \\
(.11)\end{array}$ & $\begin{array}{l}.28 * * \\
(.11)\end{array}$ \\
\hline Ln GDP per capita $t-1$ & $\begin{array}{l}-.005 \\
(.007)\end{array}$ & $\begin{array}{l}.001 \\
(.029)\end{array}$ & $\begin{array}{l}.012 \\
(.052)\end{array}$ & $\begin{array}{l}.005 \\
(.075)\end{array}$ & $\begin{array}{l}-.019 \\
(.115)\end{array}$ & $\begin{array}{l}.002 \\
(.004)\end{array}$ & $\begin{array}{l}.03 \\
(.02)\end{array}$ & $\begin{array}{l}.13^{* * * *} \\
(.04)\end{array}$ & $\begin{array}{l}15 * * * \\
(.05)\end{array}$ & $\begin{array}{l}.22 * * \\
(.09)\end{array}$ & $\begin{array}{l}-.001 \\
(.005)\end{array}$ & $\begin{array}{l}.02 \\
(.03)\end{array}$ & $\begin{array}{l}.04 \\
(.05)\end{array}$ & $\begin{array}{l}-.03 \\
(.06)\end{array}$ & $\begin{array}{l}.09 \\
(.11)\end{array}$ & \\
\hline Leader exited $t_{t-1}{ }^{a}$ & & & & & & & & & & & $\begin{array}{l}-.08 * * \\
(.04)\end{array}$ & $\begin{array}{l}-.27 * * \\
(.12)\end{array}$ & $\begin{array}{l}-.64 * * \\
(.25)\end{array}$ & $\begin{array}{l}-1.06 * * * \\
(.36)\end{array}$ & $\begin{array}{l}-.84 \\
(.58)\end{array}$ & $\begin{array}{l}.05 \\
(.05)\end{array}$ \\
\hline $\begin{array}{l}\text { Ln GDP per capita } t-1 * \\
\text { leader exited } t-1\end{array}$ & & & & & & & & & & & $\begin{array}{l}.012 * * \\
(.005)\end{array}$ & $\begin{array}{l}.04 * * \\
(.02)\end{array}$ & $\begin{array}{l}.10 * * * \\
(.03)\end{array}$ & $\begin{array}{l}.16^{* * * *} \\
(.05)\end{array}$ & $\begin{array}{l}.13^{*} \\
(.08)\end{array}$ & \\
\hline $\begin{array}{l}\text { Average years schooling } \\
\text { (age } 15 \text { and over) } t-1\end{array}$ & & & & & & & & & & & & & & & & $\begin{array}{l}.02 \\
(.03)\end{array}$ \\
\hline $\begin{array}{l}\text { Average years schooling } t-1 * \\
\text { leader exited } t-1\end{array}$ & & & & & & & & & & & & & & & & $\begin{array}{l}.03 * * \\
(.02)\end{array}$ \\
\hline $\begin{array}{l}\text { Cumulative effect } \\
\text { of income }\end{array}$ & -.04 & .00 & .01 & .01 & -.02 & .03 & .09 & $.18 * * *$ & $.20 * * *$ & $.25 * *$ & & & & & & \\
\hline $\begin{array}{l}\text {-if leader exited } \\
\text {-if leader stayed }\end{array}$ & & & & & & & & & & & $\begin{array}{l}.12 \\
-.01\end{array}$ & $\begin{array}{l}.12 * * \\
.03\end{array}$ & $\begin{array}{l}.17 * * * \\
.05\end{array}$ & $\begin{array}{l}.16^{* *} \\
-.03\end{array}$ & $\begin{array}{l}.22 * * \\
.09\end{array}$ & \\
\hline $\begin{array}{l}\text { Cumulative effect } \\
\text { of schooling }\end{array}$ & & & & & & & & & & & & & & & & \\
\hline $\begin{array}{l}\text {-if leader exited } \\
\text {-if leader stayed }\end{array}$ & & & & & & & & & & & & & & & & $\begin{array}{l}.07 * \\
.02\end{array}$ \\
\hline Fisher $\mathrm{p}$ level & {$[.00]$} & {$[.00]$} & {$[.00]$} & {$[.00]$} & {$[.95]$} & {$[.00]$} & {$[.00]$} & {$[.00]$} & {$[.00]$} & {$[.00]$} & {$[.00]$} & {$[.00]$} & {$[.00]$} & {$[.00]$} & {$[.06]$} & {$[.00]$} \\
\hline Observations & 5,358 & 1,099 & 560 & 329 & 277 & 8,216 & 1,573 & 730 & 474 & 340 & 6,425 & 1,233 & 601 & 396 & 291 & 416 \\
\hline Countries & 158 & 158 & 136 & 135 & 131 & 140 & 137 & 123 & 123 & 116 & 134 & 132 & 119 & 120 & 113 & 65 \\
\hline R-squared & .9492 & .8274 & .7780 & .8038 & .8135 & .8836 & .6422 & .5852 & .6261 & .6925 & .8703 & .6237 & .6037 & .6745 & .7343 & .5569 \\
\hline
\end{tabular}

Sources: see Table A18.

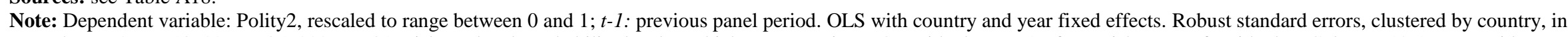

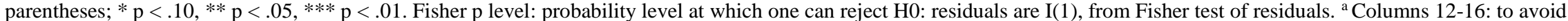

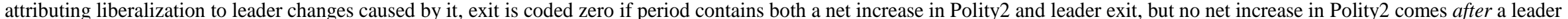
exited. 
The new point I emphasize is that the income-democracy link is strongest in the medium run - panels of 10-20 years. Year on year, measures of democracy usually change little: the coefficient on lagged democracy in one-year panels is close to one. But as the gap between observations increases, the coefficient falls; in 20-year panels, it is near zero or negative, suggesting regression to the mean. To predict how democratic a country will be next year, its current democracy level is definitive. But to forecast 20 years ahead, its income is far more informative. ${ }^{13}$ In most years, institutions are inertial. But in some, accumulated increases in income trigger bursts of political progress.

What initiates re-equilibration? There may be several factors. Here I focus on one. I argue that in nondemocracies economic development affects politics mostly in periods after the ruler exits. Under a long-serving dictator, society may grow more complex, bourgeois, educated, and autonomous without forcing political reform. Yet when the dictator departs — whether ousted in a revolution or dying peacefully in bed-political practices often converge with new socioeconomic realities. Leader turnover alone does not produce democracy: in poor countries, one dictator usually replaces another. Development alone only makes democracy more feasible; and, as I show later, in the short run higher growth entrenches dictators. It is the combination of development and leader change that increases the odds of political reform.

Table 2, panel C, shows evidence. I use an interaction term to examine whether income affects democracy differently when the leader has recently exited. ${ }^{14}$ Leadership data come from the

\footnotetext{
13 The effects are quite large. The difference between per capita GDP of \$2,000 and \$20,000 corresponds to a long-term difference of .58 on the 0-1 Polity2 scale using the estimate from Panel B (20-year data).

${ }^{14}$ For instance, in the 5-year panel I distinguish cases in which there was at least one change of leader in years $t-5$ through $t-1$ from those in which there was none. I also adjust to avoid attributing liberalization to leader change that did not precede it: exit is coded zero if the period contains both a net increase in Polity 2 and leader exit, but no net increase in Polity 2 comes after a leader exit. For example, in the 5-year panel, if Polity2 rose in years 1 to 3, then plateaued, and the leader exited in year 3 or 4, I would code this period as not containing (the relevant sort of) leader change. (In fact, results are similar even without this adjustment.)
} 
Archigos dataset (Goemans et al. 2009a, 2009b), covering all independent states between 1875 and 2004. A country's "leader" is "the person that de facto exercised power" - in general, the prime minister in parliamentary regimes, the president in presidential and mixed ones, and the communist party chairman in communist states (Goemans et al. 2009a). As before, the dependent variable is rescaled Polity2, restricting attention to non-democracies.

Income now has a large effect after leader turnover (significant in 5- to 20-year panels), and no effect at all if no leader exited. Figure 1A shows the predicted one-year change in rescaled Polity 2 with and without leader change in the previous year. Figure $1 \mathrm{~B}$ shows the difference between the predicted Polity2 changes with and without prior leader exit. ${ }^{15}$

Model 16 suggests one mechanism by which development stimulates liberalization. As countries develop, citizens become better educated, which increases their desire to participate politically, capacity to organize, and tolerance (Lipset 1959, Barro 1999, Przeworski et al. 2000, Glaeser et al. 2004). It may also reduce inequality and accelerate growth, indirectly facilitating democratization. However, Acemoglu et al. (2005) argue that country and year fixed effects eliminate the relationship between education and democracy. For education, I use estimates of average years of schooling among those 15 and older (Morrisson and Murtin 2009). The effect of education—insignificant without leader turnover — is larger and significant after leader exit. ${ }^{16}$

In the appendix, I show one gets similar results using an error correction model to estimate the equilibrium relationship between income and democracy to which the system heads in post-

\footnotetext{
15 See Figure A1 for 10 year panel.

${ }^{16}$ Results are similar focusing on transitions to democracy or excluding interpolated income data (Table A2). OLS with fixed effects and lagged dependent variable can yield biased estimates ("Nickell bias"). Results are similar if the lagged dependent variable is dropped (Table A3; the cost is autocorrelation and less precise estimates; clustered standard errors, nevertheless, remain consistent). Table A5 provides descriptive statistics. Table A6 shows results change little if one varies the panel's starting year.
} 
turnover years (Table A4). A doubling of GDP per capita increases the equilibrium value of rescaled Polity2 by about .18. I also discuss various other possible estimation strategies, explaining why the one shown here better suits the question at hand.

\section{Robustness and identification}

The effect of income, conditional on leader change, is quite robust to controlling for other possible determinants of regime type — democracy in neighbors; trade dependence; mineral wealth; authoritarian subtype; political history; previous transitions; past violent leader changes; and war or civil war (Table A7). Some controls correlate with democracy as previously suggested; others do not in this demanding setting. All at most slightly weaken the estimated impact of income conditional on leader turnover, and quite often the effect increases. ${ }^{17}$ Various scholars have studied the role that elections play in authoritarian regimes (for a review, see Gandhi and Lust-Okar 2009). Could it be elections that activate the impact of income on democracy, rather than leader turnover per se? In fact, controlling for the holding of legislative and executive elections, the effect of income interacted with leader change is even stronger, and the coefficients on the electoral dummies are negative (Table A7, column 5). As one might expect, leader turnover makes an even bigger difference in regimes without elections than in those with them. And in years without leader exit, elections do not cause democratization.

\footnotetext{
${ }^{17}$ For evidence that income's impact is causal, see Boix (2011).
} 
Figure 1A: Predicted increase in democracy in $t$, with and without leader change in t-1, non-democracies, 1875-2004

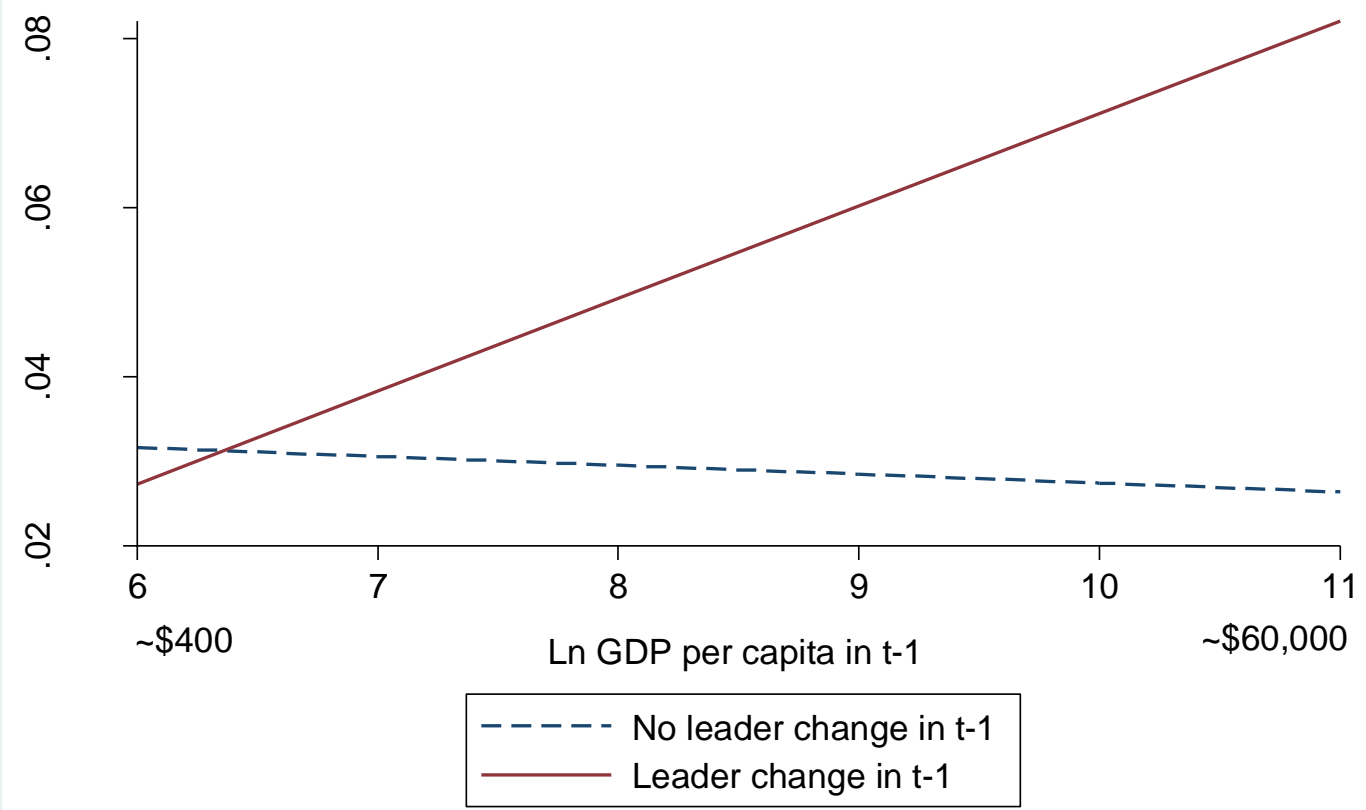

Source: See Table A18; calculated from Table 2, model 11. One-year panel.

Figure 1B: Difference in predicted increase in democracy in t, with leader change in t-1 compared to without, non-democracies, 1875-2004

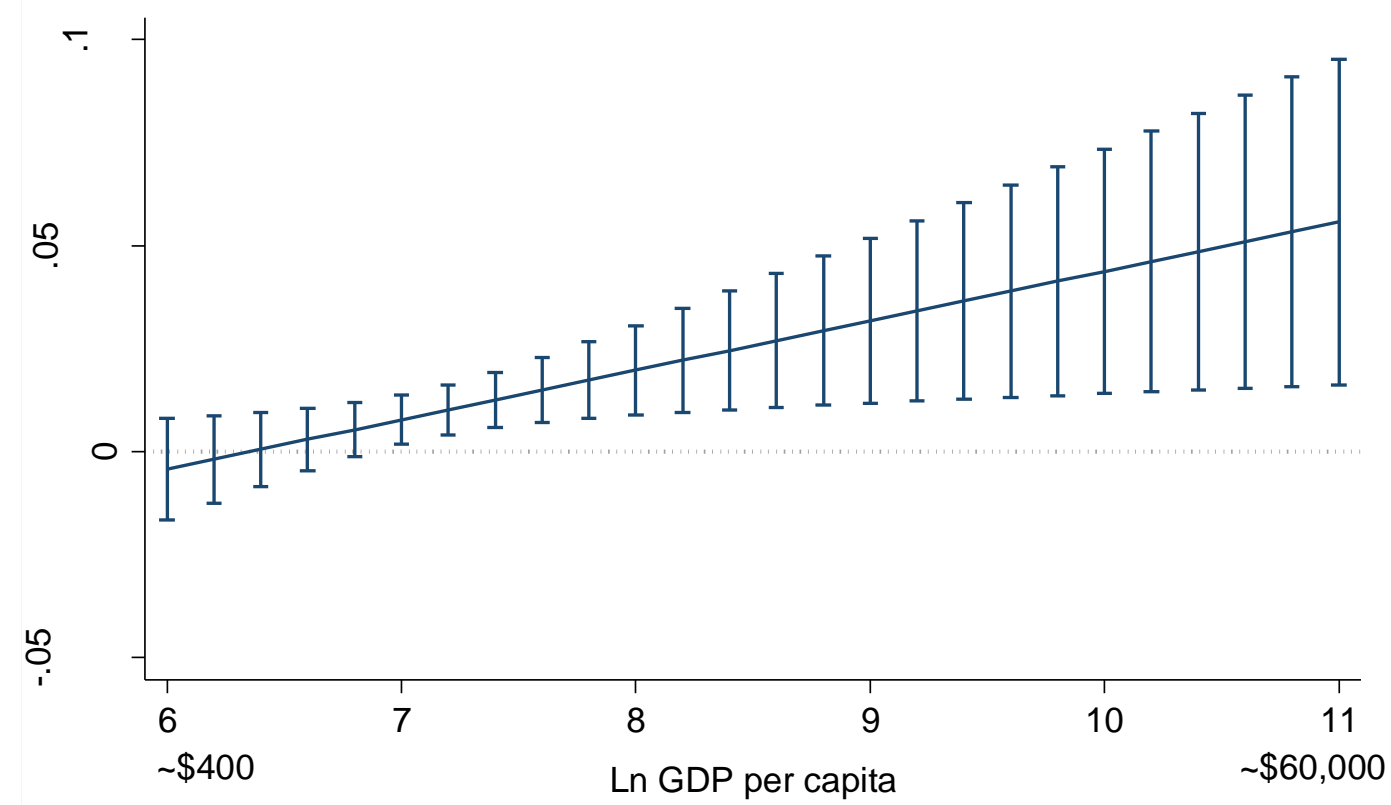

Source: See Table A18; calculated from Table 2, model 11; 95 percent confidence intervals. One-year panel. 
So far I have established an interesting pattern. If nothing else, leader exit signals that the influence of income has been "switched on." This helps explain why efforts to relate development to democracy produce sometimes conflicting results that are sensitive to period and lag structure. But is leader exit more than just a signal? Does a dictator's departure cause income to matter more? There are two threats to such inferences. First, democracy might increase leader turnover rather than the reverse. Second, some third factor might cause both democratization and leader change.

Consider reverse causation. Of course, political liberalization-which generally involves holding competitive elections - itself often produces leader change. However, in such cases we should expect leader turnover after or perhaps simultaneously with political reform. In the multiyear panels, when liberalization does occur I only code leader turnover as present if the leader turnover occurred strictly before some net increase in Polity2. It is implausible that such leader replacement was caused by reforms that it preceded. Another possible worry is that Polity coders simply take leader change as a sign of liberalization. In fact, as I show in the appendix (p.13), they clearly do not equate the two.

One way to exclude reverse causation is to examine types of leader exit unlikely to result from domestic political processes. A good candidate is the dictator's peaceful death in office. Although everyone dies, the timing of death by natural causes usually has little to do with political or economic events. Indeed, previous work has used leaders' natural deaths to statistically identify the effects of their actions. As Jones and Olken (2005) argue, in cases of natural death, the timing of leader turnover is "essentially random."

Table 3, column 1, shows the impact of income on the rescaled Polity 2 change during the 10 years after a dictator's natural death. A decade later, countries with per capita GDP of \$10,000 had increased their score by .19 more than had countries with income of $\$ 1,000$. For comparison, 
column 2 shows the Polity 2 change for all nondemocracy-decades in which no leader died of natural causes. (Since a leader did generally exit in some other way, my argument predicts quite a strong relationship here as well.) Among these cases, a tenfold difference in income is associated with a .10 difference in Polity2. Finally, in decades with no leader turnover (column 3), political change was unrelated to income. ${ }^{18}$

Table 3: Marginal effect of income on 10-year increase in Polity2

Coefficient on lagged log GDP per capita from regression of change in Polity2 (0 to 1) from year t to $t+10$

\begin{tabular}{|c|c|c|c|c|c|c|}
\hline & \multicolumn{2}{|c|}{$\begin{array}{l}\text { Among nondemocracies } \\
\text { whose leader died of } \\
\text { natural causes in yeart }\end{array}$} & \multicolumn{2}{|c|}{$\begin{array}{l}\text { Among nondemocracies whose } \\
\text { leader did not die in years } t \text { to } t+10 \\
\text { (but may have exited another way) }\end{array}$} & \multicolumn{2}{|c|}{$\begin{array}{l}\text { Among nondemocracies } \\
\text { with no leader exit } \\
\text { in years t to } t+10\end{array}$} \\
\hline & (1) & +2 & (2) & & (3) & \\
\hline & $.19 * * *$ & & $.10 * * *$ & & .00 & \\
\hline & $(.07)$ & & $(.01)$ & & $(.01)$ & \\
\hline \multirow[t]{5}{*}{$N$} & 100 & & 4,747 & & 1,659 & \\
\hline & $\begin{array}{l}\text { After year } \\
\text { of global } \\
\text { recession in } \\
\text { which leader } \\
\text { exited }\end{array}$ & $\begin{array}{l}\text { After year of } \\
\text { global recession } \\
\text { with no leader } \\
\text { exit in years } t \text { to } \\
t+10\end{array}$ & $\begin{array}{l}\text { All 10-year } \\
\text { periods with no } \\
\text { year of global } \\
\text { recession plus } \\
\text { leader exit }\end{array}$ & $\begin{array}{l}\text { After year } \\
\text { of military } \\
\text { defeat in } \\
\text { which leader } \\
\text { exited }\end{array}$ & $\begin{array}{l}\text { After year of } \\
\text { military defeat } \\
\text { with no leader } \\
\text { exit in years } t \text { to } \\
t+10\end{array}$ & $\begin{array}{l}\text { All 10-year } \\
\text { periods with } \\
\text { no year of } \\
\text { military defeat } \\
\text { plus leader exit }\end{array}$ \\
\hline & (4) & $(5)$ & (6) & (7) & $(8)$ & (9) \\
\hline & $.33 * *$ & .07 & $.04 * * *$ & $1.18 * * *$ & -.02 & $.10 * * *$ \\
\hline & $(.15)$ & $(.05)$ & $(.01)$ & $(.29)$ & $(.02)$ & $(.01)$ \\
\hline$N$ & 48 & 70 & 3,387 & 14 & 13 & 5,415 \\
\hline
\end{tabular}

Source: Table A18.

Notes: Robust standard errors in parentheses; $* \mathrm{p}<.10, * * \mathrm{p}<.05, * * * \mathrm{p}<.01$. Columns $7-9$ exclude wars followed by foreign occupation or imposition of leader. Coefficients in columns 5 and 8 would be, respectively, $.16(\mathrm{p}<.01)$ and $.03(\mathrm{p}=.30)$ if one required no leader exit in just the next three years.

This is quite strong evidence that — at least in some cases—-leader change itself causes political reform, which, in richer countries, enhances democracy. Of course, not all leader exits result from natural deaths. Two other causes, although not necessarily random, are relatively

\footnotetext{
${ }^{18}$ Although the timing of natural deaths is random, deaths might still be more common for certain types of countries and leaders. Table A8 checks whether deaths correlate with world region, national income, Polity2, time period, leader age, and leader tenure. Unsurprisingly, old and long-serving leaders are more likely to die naturally in office; deaths are also slightly commoner in certain regions. Table A9, therefore, presents the Table 3, Panel A, regressions controlling for region, age, and tenure. Results are similar, with a stronger estimated income effect.
} 
external: defeat in war and international recession. Leader turnover during these is unlikely to reflect some purely domestic political process. (Of course, we still need to check recession and military defeat do not themselves cause democratization, absent leader exit.)

Table 3, column 4, shows the impact of income on the Polity2 change in the decade after a leader exited during a global recession. For each country, $i$, I define a global recession as a year in which the average growth rate in all other countries, weighted by their recent share in trade with country $i$, is negative. Again, liberalization in such periods increases with the country's income. Income had a much smaller effect — if any_-after global recessions that did not prompt leader turnover, and also in decades containing no years of global recession plus leader exit. When a leader departs amid military defeat, the Polity2 increase correlates very closely with income (column 7). (I exclude wars followed within 10 years by foreign occupation or imposition of a leader since occupation by a democratic power can obviously produce democracy.) In decades containing no year of military defeat plus leader exit the income effect was much weaker, and there was no effect after military defeats that did not produce leader change. ${ }^{19}$

Besides reverse causation, some third factor might cause both leader turnover and subsequent democratization. To be clear, this does sometimes happen. After World War II, Germany's Allied occupiers both replaced its Nazi leaders and introduced democratic institutions. Pro-democracy movements sometimes sweep away both ruler and regime. However, the evidence shows that such cases are not driving the results.

\footnotetext{
${ }^{19}$ Leaders facing domestic opposition might initiate wars hoping to rally support. Results are similar excluding cases where the dictator started the war (coefficient: $1.01, \mathrm{p}<.10$ ). Leaders in some authoritarian subtypes may be more sensitive to military defeat or economic crisis. Geddes (1999) argues that military regimes are more vulnerable to economic downturns. Weeks (2009) and Debs and Goemans (2010, p.440) discuss whether leaders are more likely to fall after military defeat in different subtypes. The latter finds no significant differences. Table A9 (Panels A and B) shows that results for both recessions and military defeat are similar controlling for subtype.
} 
Various country characteristics might cause them to change leaders frequently and-given modernization - to democratize. We can exclude these as a group. Table A10 shows that controlling for a country's recent rate of leader turnover (over 20, 10, or 5 years) and its interaction with income changes little. What matters is not that countries have a propensity to replace leaders: they must have just replaced one.

I consider the following possible confounding factors. First, global recessions and military defeats prompt leader change that clearly does not result from domestic liberalization; but do these factors themselves cause richer countries to democratize? Kennedy (2010), for instance, showed that low economic growth predicts major institutional change, the direction of which depends on the country's income. Although I excluded cases where foreign victors imposed democracy, military defeat might itself incline richer countries to reform. Second, popular mobilization might both oust the ruler and install free institutions. ${ }^{20}$ Third, Miller (2012) argued that economic development affects democratization "only in distinctive periods of regime vulnerability." State weakness provokes both violent leader turnover and-in more developed countries-liberalization. Fourth, certain subtypes of nondemocracy might be more susceptible to both leader turnover and reform.

Do these factors prompt leader change? In nondemocracies, exit is more common in years of low economic growth or military defeat, and when the number of antigovernment demonstrations is high and rising (Table A12). Instrumenting for growth with trade-weighted average growth in other countries suggests it has a causal impact. To capture state weakness, I use four indicators: the

\footnotetext{
${ }^{20}$ To measure opposition mobilization, I use Chenoweth and Stephan's (2011) record of mass resistance campaigns and Banks' (2007) counts of antigovernment demonstrations, general strikes, riots, and attempted revolutions (previously used by, e.g., Bueno de Mesquita and Smith 2010, Alemán and Yang 2011.) These are compiled from newspapers, which raises concern reports might be censored in countries with media restrictions. In fact, using Freedom House's index of press freedom, I show recorded mobilization events correlate negatively with press freedom (Table A11). Still, a conservative approach is to focus on annual changes rather than levels, assuming censoring remains relatively constant (Bueno de Mesquita and Smith 2010).
} 
number of assassinations of high officials, incidence of guerrilla war, civil war, and "major government crisis," defined as "any rapidly developing situation that threatens to bring the downfall of the present regime - excluding situations of revolt aimed at such overthrow" (Banks 2007). ${ }^{21}$ Leader turnover proves significantly more likely in years of civil war and government crisis. Finally, leaders change more frequently in military and personalist dictatorships than in monarchies or one-party regimes. ${ }^{22}$

Might any of these factors be what activates income's influence? Table A13 uses interaction terms to check this. For each factor $x$, I compare the impact of income on democracy: (a) with $x$ but no leader exit, (b) with $x$ and leader exit, and (c) with leader exit but no $x$. Table 4 summarizes key results. Without leader exit, none of these factors triggers the income-democracy relationship, except possibly civil war (not statistically significant). Economic contraction and military defeat seem to boost income's impact if they prompt leader change. ${ }^{23}$ Without these factors, the effect of income given leader exit—ranging from .10 to .16-remains comparable to the .12 found in Table 2. In short, although recession, military defeat, opposition mobilization, and state weakness may all make leader exit more likely, and some may enhance its impact, none can plausibly explain away its influence. $^{24}$

\footnotetext{
${ }^{21}$ Examples include the 1958 Turkish economic crisis and the 1968 massacre of Mexican students.

${ }^{22}$ Growth, military defeat, antigovernment demonstrations, and civil war are all less associated with exit in democracies, as one might expect given their institutionalized turnover procedures.

${ }^{23}$ Perhaps also demonstrations and government crises, but these were not significant. Antigovernment demonstrations may have a direct effect, rendering liberalization more likely (Table A13, column 3).

${ }^{24}$ One might still worry leader exit has no impact itself but merely signifies the severity of a crisis. This does not seem to be true. Even comparing an extreme recession (-10 percent growth) without leader exit to a mild recession ( 0 percent growth) with exit, income has a significant cumulative effect with exit (.15), but none without (-.02). Similarly, excluding wars with fewer than 500 battle deaths increases the estimate for military defeat without leader exit from .09 to .18 (not significant), but the effect with leader exit remains 19 times larger.
} 
Table A14 checks whether leader exit matters more in different authoritarian subtypes, using Geddes et al.'s data (from 1945) and a coarser classification based on Banks (2007; from 1920). The multiple interactions push the data to the limit, but certain points emerge. Sensitivity to income after turnover appears weakest in monarchies and relatively strong in military and "other" nondemocracies (using Banks data), although the effect takes several years for military regimes. Among Geddes' categorizations, income matters most after a personalist dictator exits.

Finally, Table A15 examines whether the mode of leader exit alters its influence. Recall that Miller (2012) associated democratization with violent leader change. In fact, I find results are most significant for regular, peaceful exits, and then deaths by natural causes. Violent leader replacements may sometimes foster democratization, but they are not driving the results.

To recap, in non-democracies, development is robustly associated with liberalization-but primarily after leaders exit. This is true after leaders die of natural causes, the timing of which is relatively exogenous, and also when leaders depart amid international recession or military defeat. Economic contraction, military defeat, popular mobilization, government crises, and civil war may prompt leader turnover and — in some cases — accentuate its impact, but they do not activate the income effect if the old ruler survives. The results are clearest for military and personalist dictatorships, weakest for monarchies. Regular, peaceful transitions have a stronger effect than violent ones.

Faster economic growth helps dictators survive (Table A12). But high income makes liberalization more likely after the leader exits (Tables 2, A2). Combining these points, we see the autocrat's dilemma. Most dictators do not wish to undermine their regime-many hope to hand power securely to relatives or associates - yet self-interest leads them to support gradual changes in economy and society that eventually produce democratization. If shocks such as international 
recessions or world wars lead to ruler replacement in many countries simultaneously, this may help explain coordinated waves of liberalization in countries that have developed rapidly. ${ }^{25}$

\section{Table 4: Cumulative effect of income on political liberalization, with various Dossible confounding factors}

\begin{tabular}{|c|c|c|c|c|}
\hline & \multicolumn{2}{|c|}{ No exit ${ }_{t-1}$} & \multicolumn{2}{|c|}{ Exit $_{t-1}$} \\
\hline \multicolumn{5}{|l|}{ Economic crisis } \\
\hline $\begin{array}{l}\text { Growth }_{\mathrm{t}-1}=0 \% \\
\text { Growth } \mathrm{t}-1=-5 \% \\
\text { Growth }_{\mathrm{t}-1}=-10 \%\end{array}$ & $\begin{array}{l}.00 \\
-.01 \\
-.02\end{array}$ & $\begin{array}{l}(.06) \\
(.06) \\
(.06)\end{array}$ & $\begin{array}{l}.15^{*} \\
.18^{*} \\
.21^{*}\end{array}$ & $\begin{array}{l}(.09) \\
(.10) \\
(.11)\end{array}$ \\
\hline \multicolumn{5}{|l|}{ Military defeat } \\
\hline $\begin{array}{l}\text { Country lost war }{ }_{\mathrm{t}-1}^{\mathrm{a}} \\
\text { Country did not lose war }{ }_{\mathrm{t}-1}\end{array}$ & $\begin{array}{l}.09 \\
-.01\end{array}$ & $\begin{array}{l}(.17) \\
(.06)\end{array}$ & $\begin{array}{l}3.5^{* *} \\
.10\end{array}$ & $\begin{array}{l}(1.3) \\
(.09)\end{array}$ \\
\hline \multicolumn{5}{|l|}{ Popular mobilization } \\
\hline $\begin{array}{l}\text { Simultaneous with exit } \\
\text { Increase of } 2 \text { anti-government demonstrations } \mathrm{t}-1 \\
\text { No increase } \mathrm{t}-1\end{array}$ & $\begin{array}{l}.07 \\
.00\end{array}$ & $\begin{array}{l}(.08) \\
(.06)\end{array}$ & $\begin{array}{l}.19 \\
.11\end{array}$ & $\begin{array}{l}(.13) \\
(.09)\end{array}$ \\
\hline $\begin{array}{l}\text { After exit } \\
\text { Increase of } 2 \text { anti-government demonstrations }{ }_{\mathrm{t}} \\
\text { No increase } \text { t }_{\mathrm{t}}\end{array}$ & $\begin{array}{l}-.07 \\
.01\end{array}$ & $\begin{array}{l}(.06) \\
(.06)\end{array}$ & $\begin{array}{l}-.02 \\
.12\end{array}$ & $\begin{array}{l}(.12) \\
(.09)\end{array}$ \\
\hline \multicolumn{5}{|l|}{ State weakness } \\
\hline $\begin{array}{l}\text { One assassination attempt }{ }_{\mathrm{t}-1} \\
\text { No attempts } \mathrm{t}_{\mathrm{t}-1}\end{array}$ & $\begin{array}{l}.00 \\
.01\end{array}$ & $\begin{array}{l}(.07) \\
(.06)\end{array}$ & $\begin{array}{l}.06 \\
.16^{*}\end{array}$ & $\begin{array}{l}(.09) \\
(.10)\end{array}$ \\
\hline $\begin{array}{l}\text { Guerrilla warfare } \mathrm{t}_{\mathrm{t}} \\
\text { No guerrilla warfare } \mathrm{t}_{\mathrm{t}-1}\end{array}$ & $\begin{array}{l}.01 \\
.01\end{array}$ & $\begin{array}{l}(.07) \\
(.06)\end{array}$ & $\begin{array}{l}.11 \\
.14\end{array}$ & $\begin{array}{l}(.09) \\
(.09)\end{array}$ \\
\hline $\begin{array}{l}\text { Civil war }{ }_{\mathrm{t}-1} \\
\text { No civil war } \mathrm{t}-1\end{array}$ & $\begin{array}{l}.12 \\
-.00\end{array}$ & $\begin{array}{l}(.10) \\
(.05)\end{array}$ & $\begin{array}{l}.14 \\
.13\end{array}$ & $\begin{array}{l}(.18) \\
(.08)\end{array}$ \\
\hline $\begin{array}{l}\text { Major government crisis } \mathrm{t}-1 \\
\text { No crisis } \mathrm{t}_{\mathrm{t}-1}\end{array}$ & $\begin{array}{l}.03 \\
.02\end{array}$ & $\begin{array}{l}(.08) \\
(.06)\end{array}$ & $\begin{array}{l}.16 \\
.10\end{array}$ & $\begin{array}{l}(.10) \\
(.08) \\
\end{array}$ \\
\hline
\end{tabular}

Source: Table A13

Note: OLS, country and year fixed effects.One-year panels. Robust standard errors, clustered by country, in parentheses; $* \mathrm{p}<.10, * * \mathrm{p}<.05 .{ }^{\mathrm{a}}$ excluding defeats followed (within 10 years) by foreign occupation or imposition of leader.

\footnotetext{
${ }^{25}$ Some authors suggest the effect of income differs across historical periods and is weaker after 1945 (Boix 2011). Treisman (2013) examines this. Using interaction terms to distinguish pre-1945 and post-1945 income effects, while controlling for country and year, I find no evidence income matters less after 1945.
} 


\section{Why leader exit matters}

Why does leader turnover temporarily activate the effects of development? How do long-serving dictators block political change, despite economic and social modernization? Four sets of answers seem plausible. They concern the environments new leaders encounter, characteristics of entering leaders, their evolution in office, and selection via the filter of political survival.

New leaders face a distinctive environment with threats from inside and outside. The previous dictator's departure often provokes a succession struggle. This can foster liberalization in several ways. Factions, when deadlocked, may settle on a power-sharing arrangement organized as oligarchical democracy. The leader may appeal to outsiders for support, broadening participation. Over time, dictators that survive disempower rival factions, appointing loyalists to key positions (Svolik 2012). The turnover often provides a focal point for opposition mobilization, which the regime, internally divided, may have trouble repressing. In richer societies, this may produce political concessions or democratic revolution. Beset by factional conflict, military leaders may return to the barracks to restore cohesion.

Besides encountering distinctive conditions, new leaders in modernizing autocracies differ from their predecessors. Some take power in popular revolutions. In poorer countries, revolutionaries tend to be nationalists, religious fundamentalists, communists, or authoritarian populists. In developed ones, they are sometimes democrats. Still, most democratizations do not coincide with popular mobilization. ${ }^{26}$ Even regime insiders appointed amid modernization will

\footnotetext{
${ }^{26}$ Between 1900 and 2006, Boix et al. (2012) record 128 cases of democratization; of these, only 32 occurred during a mass resistance campaign, as identified by Chenoweth and Stephan (2011). Only one third of democratizations were in the same year as an antigovernment demonstration.
} 
often have better education and more liberal values than their predecessors (Inglehart and Welzel 2005).

Whatever their initial characteristics, leaders change in office. Most obviously, they grow older; studies correlate age with conservatism (Truett 1993). Seasoned leaders may be more riskaverse and routine-bound, new ones more activist and mistake-prone. Over time, dictators may acquire an image of impregnability and perfect techniques of repression.

Whether or not individual rulers change, selection will prune their ranks. Leaders who democratize or succumb to democratic revolution leave the pool of nondemocracies. Those remaining after some years will be tougher nuts to crack, less prone to liberalize however modern their society. ${ }^{27}$ Selection may also operate on regime types. Since military juntas are less averse to liberalization (Geddes 1999), fewer generals will remain among long-serving dictators.

Adjudicating among these mechanisms is no small task. Still, the data offer some hints. Consider the environment. As Figure A3.A shows, popular mobilization-whether antigovernment demonstrations, general strikes, riots, or attempted revolutions - tends to rise before leader transition, peak in the turnover year, then fall. (No mobilization precedes rulers' natural deaths, but — consistent with the focal point argument—demonstrations increase temporarily afterwards: Figure A3.B.) Does higher-than-average mobilization explain why income then influences liberalization? Whereas increased mobilization simultaneous with leader exit is associated with a strong (although not quite significant) income effect $(.19, \mathrm{p}=.14$, Table 4$)$, more demonstrations after leader exit predict no income effect at all $(-.02, \mathrm{p}=.88)$. Elite divisions might increase income's influence in the post-turnover year-I lack data on these; popular mobilization apparently does not.

${ }^{27}$ For a similar argument about democratic leaders, see Zaller (1998). 
That leaves change in characteristics of leaders (and regimes) and in the pool of survivors. How to assess the impact of selection? Suppose certain fixed characteristics of leaders or regimes"selection characteristics"-render them less likely to democratize and lose office. Call leaders endowed with these "reactionaries," those lacking them "reformers." The proportion of reactionaries among leaders in office after $T$ years will increase with $T$. A leader's total tenure can proxy for his position on the reformist-reactionary scale. Interacting his tenure with national income, one can estimate the impact of selection on the income-democratization relationship. Controlling for this, if income still influences liberalization more early on, this probably reflects change in individual leaders rather than selection. ${ }^{28}$

Estimations employing this strategy suggest selection is important. I regress Polity2 on its lag, income, the leader's total tenure, dummies for his current year in office, and all interactions of these three, plus country and year dummies. ${ }^{29}$ Since the many interaction terms are cumbersome, I present results graphically. The longer a leader will serve, the less he reforms in any year of his term (Figure 2), and the less his decision depends on the country's income (Figure 3, showing effects in first year). "Reactionaries" who survive 17 years do not respond to higher development even in their first. However, selection is not everything. Even "reformist" leaders, selected out quickly, mostly respond to income in their first year (Figures A4.A-C). ${ }^{30}$

On what characteristics does selection operate? Consider higher education. Even controlling for country and year, the share of leaders in nondemocracies with college degrees falls from 58 percent in their first year to 36 percent in their thirtieth. And college graduates liberalize more than

\footnotetext{
${ }^{28}$ We must assume selection characteristics remain fixed and that the logic of selection does not change. In the short term, this seems reasonable.

${ }^{29}$ Breaking leaders' current year in office into dummies, one can assess whether the first year is different for leaders with various total term lengths.

${ }^{30}$ For those that survive, income's influence rises again in the sixth year, but the effect is insignificant.
} 
Figure 2: Selection effects: Predicted change in Polity2, non-democracies, 1875-2004, median GDP per capita, starting from Polity2 = 0

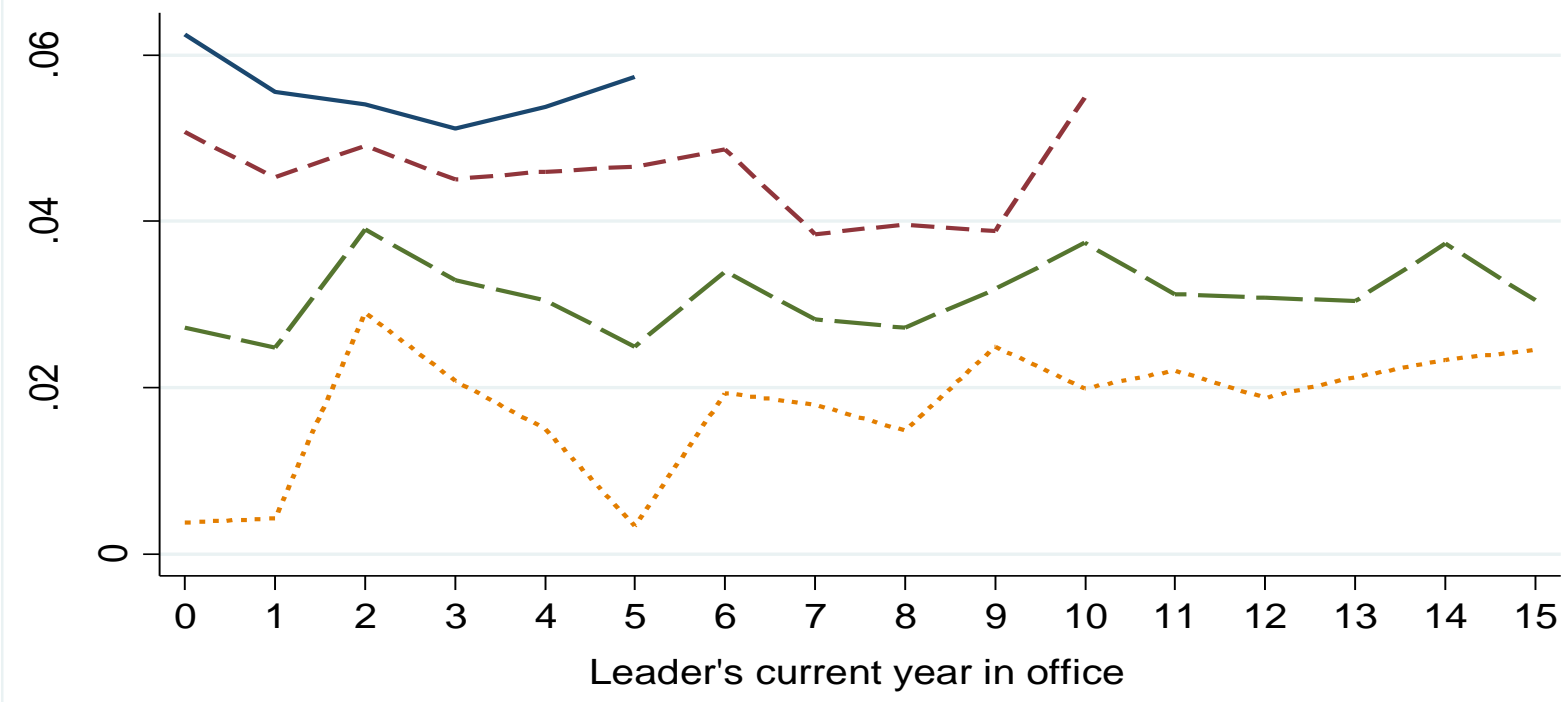

- leader will serve 5 years $\quad-----$ leader will serve 10 years

— - leader will serve 20 years .......... leader will serve 30 years

Source: See Table A18.

Figure 3: Selection effects: Marginal effect of Ln GDP per capita on Polity2 in the leader's first year, by leader's total term, non-democracies, 1875-2004

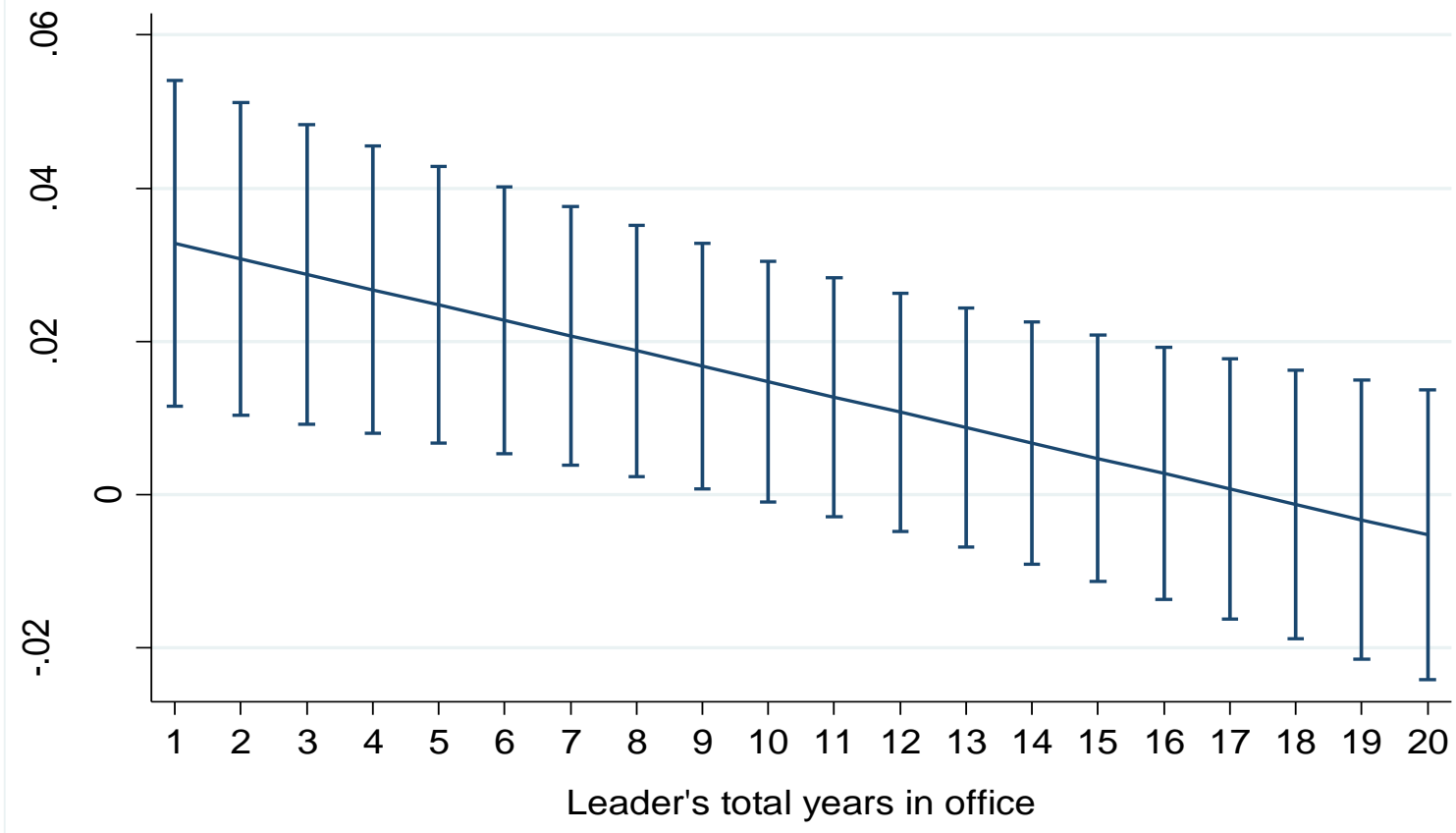

Source: See Table A18; Note: 95\% confidence intervals. 
others in richer nondemocracies (Table A16, column 1). At income of $\$ 1,000$ a year, collegeeducated dictators reform no more than uneducated ones; at $\$ 10,000$, graduates increase Polity 2 by .25 more.

Another characteristic is democratic values. Little data exist on dictators' psychology, but if individuals acquire life-long orientations by early adulthood (Sears and Levy 2003) and social values track development (Inglehart and Welzel 2005), we might expect leaders' attitudes to correlate with the development level in their youth. As a proxy, I use national income when the leader was 20. Controlling for country and year, the share of leaders who came of age in richer societies does decrease with tenure, consistent with selection out of those with modern values. And those with more modern values reform more in richer nondemocracies (Table A16, column 2). ${ }^{31}$

Leaders last longer in certain authoritarian subtypes. Since 1945, military dictatorships accounted for 16 percent of leaders in their first year, ten percent of those in their tenth. Military regimes liberalize more than others at most income levels, and the difference increases with the country's income (Table A16, column 3).

In short, in more developed autocracies, leaders with college degrees, who matured in modern societies, or who lead military dictatorships liberalize more and are selected out over time. Long-serving autocrats more often have no higher education, pre-modern values, and lead oneparty, personalist, or monarchical regimes. Selection probably also operates on harder-to-measure traits — ruthlessness, guile — but those studied here help explain why seasoned dictators rarely reform..$^{32}$

\footnotetext{
${ }^{31}$ Spilimbergo (2008) finds the number of students sent to study in democratic countries predicts increased democracy in the home country. This presumably operates via the values of future officials.

${ }^{32}$ Even if dictators are homogeneous, they may consolidate control over time, reducing odds of regime change (Svolik 2012). That could apply here, but it would not explain why characteristics of the average dictator (higher education, etc.) change as tenure increases. This is more consistent with selection.
} 
Table 5: Does activism decrease with leader tenure?

\begin{tabular}{|c|c|c|c|c|}
\hline $\begin{array}{l}\text { Dependent variable: } \\
\text { Dummy for }\end{array}$ & $\begin{array}{l}\text { Polity2 } \\
\text { moved up }\end{array}$ & $\begin{array}{l}\text { Polity2 } \\
\text { moved down }\end{array}$ & $\begin{array}{l}\text { Major } \\
\text { change to } \\
\text { constitution }\end{array}$ & $\begin{array}{l}\text { State initiated } \\
\text { militarized } \\
\text { interstate dispute }^{a}\end{array}$ \\
\hline & Polity $2_{t-1}<10$ & Polity $2_{t-1}>-10$ & All & All \\
\hline & $(1)$ & $(2)$ & (3) & (4) \\
\hline Leader's years in office & $\begin{array}{l}-.049 * * * \\
(.010)\end{array}$ & $\begin{array}{l}-.114 * * * \\
(.019)\end{array}$ & $\begin{array}{l}-.10^{* * *} \\
(.01)\end{array}$ & $\begin{array}{l}-.021 * * \\
(.009)\end{array}$ \\
\hline $\begin{array}{l}\text { Leader's years * } \\
\text { democracy dummy t-1 }\end{array}$ & $\begin{array}{l}.125 * * * \\
(.038)\end{array}$ & $\begin{array}{l}.082 * \\
(.050)\end{array}$ & $\begin{array}{l}.036 \\
(.040)\end{array}$ & $\begin{array}{l}.064 * * \\
(.032)\end{array}$ \\
\hline $\begin{array}{l}\text { Democracy dummy } \\
\quad(\text { Polity2 } \geq 6)_{t-1}\end{array}$ & $\begin{array}{l}-2.35 * * * \\
(.24)\end{array}$ & $\begin{array}{l}.35 \\
(.23)\end{array}$ & $\begin{array}{l}-.88^{* * *} \\
(.19)\end{array}$ & $\begin{array}{l}-.78^{* * *} \\
(.19)\end{array}$ \\
\hline Leader's age & $\begin{array}{l}-.001 \\
(.006)\end{array}$ & $\begin{array}{l}-.001 \\
(.007)\end{array}$ & $\begin{array}{l}.001 \\
(.005)\end{array}$ & $\begin{array}{l}-.002 \\
(.005)\end{array}$ \\
\hline Ln GDP per capita $t_{t-1}$ & $\begin{array}{l}-.91 * * * \\
(.22)\end{array}$ & $\begin{array}{l}-1.08 * * * \\
(.29)\end{array}$ & $\begin{array}{l}-.91 * * * \\
(.19)\end{array}$ & $\begin{array}{l}-.65^{* * *} \\
(.21)\end{array}$ \\
\hline Growth rate ${ }_{t-1}$ & $\begin{array}{l}-.028 * * * \\
(.008)\end{array}$ & $\begin{array}{l}-.041 * * * \\
(.011)\end{array}$ & $\begin{array}{l}-.031 * * * \\
(.007)\end{array}$ & $\begin{array}{l}-.025 * * * \\
(.008)\end{array}$ \\
\hline $\begin{array}{l}\text { Ln antigovernment } \\
\text { demonstrations } t_{t-1}\end{array}$ & $\begin{array}{l}.42 * * * \\
(.10)\end{array}$ & $\begin{array}{l}.13 \\
(.14)\end{array}$ & $\begin{array}{l}.48^{* * * *} \\
(.10)\end{array}$ & $\begin{array}{l}-.022 \\
(.087)\end{array}$ \\
\hline $\begin{array}{l}\text { Country's past rate of } \\
\text { initiating MIDs }\end{array}$ & & & & $\begin{array}{l}-.27 \\
(.77)\end{array}$ \\
\hline State's military capability $t-1$ & & & & $\begin{array}{l}4.78 \\
(4.41)\end{array}$ \\
\hline Trade as share of GDP $t-1$ & & & & $\begin{array}{l}.88^{* *} \\
(.38)\end{array}$ \\
\hline $\begin{array}{l}\text { Head of state a military } \\
\text { Officer }\end{array}$ & & & & $\begin{array}{l}.35^{*} \\
(.20)\end{array}$ \\
\hline Observations & 5,567 & 5,348 & 6,655 & 4,751 \\
\hline Countries & 119 & 104 & 131 & 110 \\
\hline
\end{tabular}

Sources: Table A18.

Note: Conditional logit fixed effects, with year dummies. Annual data. Standard errors in parentheses; $* \mathrm{p}<.10, * * \mathrm{p}<$ $.05, * * * \mathrm{p}<.01{ }^{a}{ }^{a}$ excluding years in which state does not initiate a MID but continues one it previously initiated. Cases where lagged Polity2 score equals 10 (-10) excluded in column 1 (2) since countries cannot move beyond limit of the scale.

Finally, why do autocrats in richer countries who do reform tend to do so early (Figures A4.A-C)? As noted, this could result from intra-elite competition associated with succession, or growing caution as new leaders acclimatize. In this connection, note that liberalization is not the only thing autocrats tend to do early. New dictators (but not democratic leaders) are also more likely to increase repression, make major constitutional changes, even to initiate militarized interstate 
disputes (Table 5). ${ }^{33}$ Whether because of changing psychology or conditions, the average autocrat grows more conservative in office. ${ }^{34}$

The evidence here is hardly definitive. But it is consistent with a view in which modernization increases the proportion of leaders who, whether rising via revolution or internal succession, have higher education and more liberal values. Such leaders prove readier to reform and often lose in the fairer elections they introduce. Military dictators also exit relatively quickly. Longsurviving autocrats are those most reactionary and adept at blocking change. Even among reformists, motivation to liberalize weakens after their first year. Tracing the details of this process remains a challenge for future work.

\section{Conclusion}

Economic development promotes political liberalization, but not in a smooth and incremental way. Dictators differ, and some have the determination and skill to deflect pressures for reform for decades. Breakthroughs come only after such reactionaries depart.

\footnotetext{
${ }^{33}$ Correlates of War data (Ghosn, Palmer, and Bremer 2004). Besides country and year, I control for other factors that might influence dispute initiation - trade dependence (Oneal, Russett and Berbaum 2003), economic growth (Oneal and Tir 2006), antigovernment protests (Miller 1999), military power (Bremer 1992; using COW's Composite Index of National Capability), past rate of starting international conflicts (from beginning of the data), leader's age (Horowitz, McDermott and Stam 2005), and whether he was a military officer (Lai and Slater 2006). In the regressions for change in political institutions, I control for income, growth, antigovernment protests, and leader's age, all of which could influence reform. Rather than include just nondemocracies here, I use all cases and distinguish between tenure in democracies and nondemocracies with an interaction term. Inexperienced leaders might be targeted by challengers (Gelpi and Grieco 2001), but I examine whether a leader initiates a MID. To demonstrate robustness, Table A17 shows identical regressions using a linear probability model. Chiozza and Choi (2003, p.273) report that in 1950-90 nondemocratic leaders were "slightly more conflict prone in the early phases of their tenure and slightly more inclined to seek a peaceful resolution later in their careers than their democratic counterparts." Horowitz et al. (2005) found leaders participated more in MIDs as they aged (except in personalist autocracies), but tenure was insignificant. However, they did not distinguish tenure in democracies and autocracies and examined average hostilities between a state and all others, rather than the probability a leader would initiate hostilities with at least one other state, which may explain the difference.

${ }^{34}$ Besley, Persson, and Reynal-Querol (2011) find that reforms to increase executive constraints are also more likely early in a new leader's term. Obviously, there are exceptions such as Hitler or Mao. Aging might also affect reformism, but can hardly explain the pronounced drop between first and second years.
} 
Because of this, development's effect on democracy is felt most consistently in the medium run. In modernizing autocracies, the pool of new leaders contains some with higher education and relatively liberal values. Such leaders sometimes reform —and then often lose power in the more competitive elections they introduce.

Reactionary dictators face a dilemma. While higher income prepares countries foreventual - democratization, rapid growth entrenches incumbents, increasing their revenues and popular support. Dictators like Spain's Franco encourage growth because it enhances their personal odds of survival, while unintentionally triggering social changes that spell the eventual decomposition of their regime.

This logic helps explain why modernization theory often seems at odds with current events and democratic breakthroughs come as a surprise. Under Brezhnev, Soviet society grew more educated, urban, and differentiated — with no hint of democratization. In retrospect, we see this prepared the way for a more educated and modern-thinking leader, Mikhail Gorbachev, to begin reforms. In Indonesia under Suharto, per capita GDP tripled. Yet two years before street protests overthrew him, his dictatorship seemed more secure than ever (Liddle 1996). In modernizing autocracies, a stability that observers take for granted can evaporate suddenly.

In debates on the causes of democratization, believers in structural factors and contingent action are both right—and both wrong: right in that both emphasize important elements, wrong in that they neglect how they fit together. Structural factors such as economic development shape political regimes, but not immediately and every year. Their effects are "switched on and off" by the contingencies of leadership. Reactionary leaders can delay the impact of economic development, but not forever. And their efforts to prolong their own tenure often prepare the unexpected breakthrough that will follow their demise. 


\section{References}

Acemoglu, Daron, and James A. Robinson. 2006. Economic Origins of Dictatorship and Democracy. New York: Cambridge University Press.

Acemoglu, Daron, Simon Johnson, James A. Robinson, and PierreYared. 2005. "From Education to Democracy." American Economic Review Papers and Proceedings 95(2): 44-49.

Acemoglu, Daron, Simon Johnson, James A. Robinson, and PierreYared. 2008. "Income and Democracy." American Economic Review 98(3): 808-42.

Acemoglu, Daron, Simon Johnson, James A. Robinson, and PierreYared. 2009. "Revisiting the Modernization Hypothesis.” Journal of Monetary Economics 56: 1043-58.

Alan, Sule, Bo E. Honoré, and Sören Leth-Petersen. 2008. "Estimation of Panel Data Models with Twosided Censoring." Princeton University: unpublished.

Alemán, José and David Yang. 2011. "A Duration Analysis of Democratic Transitions and Authoritarian Backslides.” Comparative Political Studies 44(9): 1123-51.

Banks, Arthur. 2007. Cross-National Time-Series Data Archive: 1815-2007. Jerusalem, Israel: Databanks International.

Barro, Robert J. 1999. “Determinants of Democracy.” Journal of Political Economy 107(6): 157-83.

Benhabib, Jess, Alejandro Corvalan, and Mark M. Spiegel. 2011. "Reestablishing the IncomeDemocracy Nexus.” Cambridge, MA: NBER, Working Paper 16832.

Besley, Timothy, Torsten Persson, and Marta Reynal-Querol. 2011. "Political Turnover and Institutional Reform: Theory and Evidence.” London School of Economics: unpublished.

Besley, Timothy and Marta Reynal-Querol. 2011. "Do Democracies Select More Educated Leaders?” American Political Science Review 105(3): 552-66.

Boix, Carles. 2011. "Democracy, Development, and the International System." American Political Science Review 105(4): 809-28.

Boix, Carles, Michael Miller, and Sebastian Rosato. 2013. “A Complete Data Set of Political Regimes, 1800-2007.” Comparative Political Studies 46(12): 1523-54.

Boix, Carles and Susan Stokes. 2003. "Endogenous Democratization.” World Politics 55(4): 51749.

Bollen, Kenneth A. 1998. "Cross-National Indicators of Liberal Democracy, 1950 to 1990," University of North Carolina: unpublished. 
Bremer, Stuart A. 1992. "Dangerous Dyads: Conditions Affecting the Likelihood of Interstate War, 1816-1965.” Journal of Conflict Resolution 36(3): 309-41.

Brückner, Markus and Antonio Ciccone. 2011. "Rain and the Democratic Window of Opportunity." Econometrica 79(3): 923-47.

Bueno de Mesquita, Bruce, and Alastair Smith. 2010. "Leader Survival, Revolutions, and the Nature of Government Finance.” American Journal of Political Science 54(4): 936-50.

Bueno de Mesquita, Bruce, Alastair Smith, Randolph M. Siverson, and James D.Morrow. 2003. The Logic of Political Survival. Cambridge, MA: MIT Press.

Carreras, Albert and Xavier Tafunell, eds. 2005. Estadísticas históricas de España: Siglos XIX - XX. Bilbao: Fundación BBVA.

Casanova, José. 1983. "Modernization and Democratization: Reflections on Spain's Transition to Democracy." Social Research 50(4): 929-73.

Chamberlain, G. 1980. "Analysis of Covariance with Qualitative Data.” Review of Economic Studies 47: 225-238.

Chenoweth, Erica, and Maria J. Stephan. 2011. Why Civil Resistance Works: The Strategic Logic of Nonviolent Conflict. New York: Columbia University Press.

Chiozza, Giacomo and Ajin Choi. 2003. "Guess Who Did What: Political Leaders and the Management of Territorial Disputes, 1950-1990." Journal of Conflict Resolution 47: 251-78.

Debs, Alexandre and H.E. Goemans. 2010. "Regime Type, the Fate of Leaders, and War." American Political Science Review 104(3): 430-45.

Epstein, David L., Robert Bates, Jack Goldstone, Ida Kristensen and Sharyn O’Halloran. 2006. "Democratic Transitions." American Journal of Political Science 50: 551-569.

Gandhi, Jennifer and Ellen Lust-Okar. 2009. "Elections under Authoritarianism." Annual Review of Political Science 12: 403-22.

Gandhi, Jennifer, and Adam Przeworski. 2007. "Authoritarian Institutions and the Survival of Autocrats." Comparative Political Studies 40(11): 1279-1301.

Geddes, Barbara. 1999. "Authoritarian Breakdown: Empirical Test of a Game Theoretic Argument." UCLA: unpublished.

Geddes, Barbara, Joseph Wright, and Erica Frantz. 2012. "Authoritarian Regimes: A New Data Set." UCLA: unpublished. 
Gelpi, Christopher, and Joseph M. Grieco. 2001. "Attracting trouble: Democracy, leadership tenure, and the targeting of militarized challenges, 1918-1992." Journal of Conflict Resolution 45: 794-817.

Ghosn, Faten, Glenn Palmer, and Stuart Bremer. 2004. "The MID3 Data Set, 1993-2001:

Procedures, Coding Rules, and Description." Conflict Management and Peace Science 21: 133-154.

Glaeser, Edward L., Rafael La Porta, Florencio Lopez-de-Silanes, and Andrei Shleifer. 2004. "Do Institutions Cause Growth?” Journal of Economic Growth 9: 271-303.

Glaeser, Edward L., Giacomo A. M. Ponzetto, and Andrei Shleifer. 2007. "Why Does Democracy Need Education?" Journal of Economic Growth 12: 77-99.

Gleditsch, Kristian S. 2008. Modified Polity P4 and P4D Data, Version 3.0., http://privatewww.essex.ac.uk/ ksg/Polity.html.

Gleditsch, Kristian S. and Jinhee L. Choung. 2004. "Autocratic Transitions and Democratization.” University of California, San Diego: unpublished.

Gleditsch, Kristian S. and Michael D. Ward. 2006. "Diffusion and the International Context of Democratization." International Organization 60(4): 911-933.

Goemans, Henk E., Kristian Skrede Gleditsch, and Giacomo Chiozza. 2009a. "Introducing Archigos: A Dataset of Political Leaders." Journal of Peace Research 46(2): 269-83.

Goemans, H.E., Kristian Skrede Gleditsch, and Giacomo Chiozza. 2009b. Archigos: A Data Set on Leaders 1875-2004, Version 2.9, University of Rochester, http://www.rochester.edu/college/faculty/hgoemans/data.htm.

Greene, W. 2003. Econometric Analysis. New York: Prentice Hall.

Horowitz, Michael, Rose McDermott and Allan C. Stam. 2005. "Leader Age, Regime Type, and Violent International Relations.” Journal of Conflict Resolution 49(5): 661-85.

Huntington, Samuel P. 1991. The Third Wave: Democratization in the Late Twentieth Century, Norman, OK: University of Oklahoma Press.

Inglehart, Ronald and Christian Welzel. 2005. Modernization, Cultural Change, and Democracy: The Human Development Sequence. New York: Cambridge University Press.

Jones, Benjamin F. and Benjamin A. Olken. 2005. "Do Leaders Matter? National Leadership and Growth since World War II." Quarterly Journal of Economics 120(3): 835-864.

Jones, Benjamin F. and Benjamin A. Olken. 2009. "Hit or Miss? The Effect of Assassinations on Institutions and War." American Economic Journal: Macroeconomics 1(2): 55-87. 
Kennedy, Ryan. 2010. "The Contradiction of Modernization: A Conditional Model of Endogenous Democratization.” Journal of Politics 72(3): 785-98.

Jones, Daniel M., Stuart A. Bremer and J. David Singer. 1996. "Militarized Interstate Disputes, 1816-1992: Rationale, Coding Rules, and Empirical Patterns." Conflict Management and Peace Science 15(2): 163-213.

Lai, Brian and Dan Slater. 2006. "Institutions of the Offensive: Domestic Sources of Dispute Initiation in Authoritarian Regimes, 1950-1992.” American Journal of Political Science 50(1): 113-26.

Li, Quan and Rafael Reuveny. 2003. "Economic Globalization and Democracy: An Empirical Analysis.” British Journal of Political Science 33(1): 29-54.

Liddle, R. William. 1996. “Indonesia: Suharto’s Tightening Grip.” Journal of Democracy 7(4): 5872.

Lipset, Seymour Martin. 1959. "Some Social Requisites of Democracy: Economic Development and Political Legitimacy.” American Political Science Review 53(1): 69-105.

Lopez-Cordova, J. Ernesto and Christopher M. Meissner. 2008. "The Impact of International Trade on Democracy: A Long-Run Perspective.” World Politics 60: 539-75.

Maddison, Angus. 2010. Historical Statistics of the World Economy, 1-2008 AD. www.ggdc.net/MADDISON/oriindex.htm.

Miller, Michael K. 2012. "Economic Development, Violent Leader Removal, and Democratization." American Journal of Political Science. 56(4): 1002-20.

Miller, Ross, 1999. "Regime Type, Strategic Interaction, and the Diversionary Use of Force." Journal of Conflict Resolution 43(3): 388-402.

Morrisson, Christian and Fabrice Murtin. 2009. "The Century of Education.” Journal of Human Capital 3(1): 1-42.

O'Donnell, Guillermo A. 1988. Bureaucratic Authoritarianism: Argentina, 1966-1973, in Comparative Perspective. Berkeley, CA: University of California Press.

Oneal, J.R. and J. Tir. 2006. "Does the Diversionary Use of Force Threaten the Democratic Peace? Assessing the Effect of Economic Growth on Interstate Conflict, 1921-2001." International Studies Quarterly 50: 755-779.

Persson, Torsten, and Guido Tabellini. 2009. "Democratic Capital: The Nexus of Political and Economic Change.” American Economic Journal: Macroeconomics 1(2): 88-126.

Pope, Devin G., and Maurice E. Schweitzer. 2011. "Is Tiger Woods Loss Averse? Persistent Bias in the Face of Experience, Competition, and High Stakes." American Economic Review 101(1): 129-57. 
Prados de la Escosura, Leandro, Joan R Rosés, and Isabel Sanz Villarroya. 2010. "Stabilization and Growth under Dictatorship: The Experience of Franco’s Spain.” CEPR Working Paper 7331.

Przeworski, Adam, Michael Alvarez, José Antonio Cheibub, and Fernando Limongi. 2000.

Democracy and Development: Political Institutions and Well-Being in the World, 1950-1990. New York: Cambridge University Press.

Russett, Bruce, John R. Oneal, and Michael L. Berbaum. 2003. "Causes of Peace: Democracy, Interdependence and International Organizations, 1885-1992.” International Studies Quarterly 47: 371-93.

Rustow, Dankwart A. 1970. "Transitions to Democracy: Toward a Dynamic Model.” Comparative Politics 2(3): 337-363

Sears, David O. and Sheri Levy. 2003. "Childhood and adult political development." In Oxford Handbook of Political Psychology, eds. David O. Sears, Leonie Huddy, and Robert Jervis. New York: Oxford University Press, 60-109.

Singer, J. David, Stuart Bremer, and John Stuckey. 1972. "Capability Distribution, Uncertainty, and Major Power War, 1820-1965." In Peace, War, and Numbers, ed. Bruce Russett. Beverly Hills: Sage, 19-48.

Spilimbergo, Antonio. 2008. "Democracy and Foreign Education.” IMF, Research Department: unpublished.

Svolik, Milan. 2012. The Politics of Authoritarian Rule. New York: Cambridge University Press.

Treisman, Daniel. 2013. “Democratization Over Time.” UCLA: unpublished.

Truett, K.R. 1993. "Age Differences in Conservatism.” Personality and Individual Differences 14: 405-411.

Weeks, Jessica. 2009. "Rulers, Risk, and Restraint: Domestic Politics and War in Authoritarian Regimes.” Cornell University: unpublished.

World Bank. 2001. World Development Indicators. Washington, DC: World Bank.

Wright, Joseph and Abel Escribà-Folch. 2012. "Authoritarian Institutions and Regime Survival: Transitions to Democracy and Subsequent Autocracy." British Journal of Political Science 42: 283309.

Zaller, John. 1998. "Politicians as Prize Fighters: Electoral Selection and Incumbency Advantage." in Party Politics and Politicians, ed. John Geer. Baltimore: Johns Hopkins University Press. 


\section{Income, Democracy, and Leader Turnover \\ Daniel Treisman*}

April 2014

Web Appendix 


\section{Calculating cumulative impact of variables in models with lagged dependent variables and interaction terms:}

In a model with a lagged dependent variable: $d_{i t}=\alpha d_{i t-1}+\gamma y_{i t-1}$, the cumulative effect of income is $\gamma /(1-\alpha)$. In a model with an interaction term: $d_{i t}=\alpha d_{i t-1}+\gamma y_{i t-1}+\delta y_{i t-1} z_{i t-1}+\varepsilon z_{i t-1}$, the cumulative effect of income is $\left(\gamma+\delta z_{i t-1}\right) /(1-\alpha)$.

In a model with three variables, $x, y$, and $z$, all of which are interacted as follows:

$d_{i t}=\alpha d_{i t-1}+\beta_{1} x_{i t-1}+\beta_{2} y_{i t-1}+\beta_{3} z_{i t-1}+\beta_{4} x_{i t-1} y_{i t-1}+\beta_{5} x_{i t-1} z_{i t-1}+\beta_{6} y_{i t-1} z_{i t-1}+\beta_{7} x_{i t-1} y_{i t-1} z_{i t-1}$ the cumulative impact of $x_{i t-1}$ is $\frac{\beta_{1}+\beta_{4} y_{i t-1}+\beta_{5} z_{i t-1}+\beta_{7} y_{i t-1} z_{i t-1}}{1-\alpha}$, the cumulative impact of $y_{i t-1}$ is $\frac{\beta_{2}+\beta_{4} x_{i t-1}+\beta_{6} z_{i t-1}+\beta_{7} x_{i t-1} z_{i t-1}}{1-\alpha}$, and the cumulative impact of $z_{i t-1}$ is $\frac{\beta_{3}+\beta_{5} x_{i t-1}+\beta_{6} y_{i t-1}+\beta_{7} x_{i t-1} y_{i t-1}}{1-\alpha}$. 
Table A1 shows that results are similar to those in Table 2, panel B, if one:

A) drops the interpolated income data.

B) focuses on transitions to democracy by including just upward movements on Polity2 in the dependent variable. The model, as in AJRY (2009), is:

$$
d_{i t}^{+}=\alpha d_{i t-1}+\gamma y_{i t-1}+\mathbf{x}^{\prime}{ }_{\mathbf{i t}-1} \boldsymbol{\beta}+\mu_{t}+\delta_{i}+u_{i t}
$$

where $d_{i t}^{+}=\max \left(d_{i t}, d_{i t-1}\right)$. This automatically drops any cases in which the democracy measure falls.

C) focuses on transitions to democracy by using the Boix-Miller-Rosato dichotomous measure of democracy (previously used in Boix and Stokes 2003 and AJRY 2009). This codes countries as democratic if elections are free and competitive, the executive is accountable (i.e. the president is directly elected or the head of government is answerable to parliament), and at least half the male population is enfranchised (Boix, Miller, and Rosato 2013). Coverage ranges from 22 countries in 1800 to 189 in 2007 . I focus on just countries that were non-democracies in the previous period and so drop the lagged dependent variable. These regressions thus capture the correlates of transitions from a score of 0 (non-democracy) to 1 (democracy). ${ }^{35}$

D) excludes just perfect democracies (those for which Polity $2_{t-1}=10$ ) rather than all democracies (those for which Polity $2_{\mathrm{t}-1} \geq 6$ ).

E) uses the estimator of Alan, Honoré, and Leth-Petersen (2008), which allows for censoring at top and bottom while controlling for unobserved heterogeneity, as in Benhabib et al. (2011).

F) uses Arellano and Bond's dynamic GMM estimator. The Arellano-Bond procedure is appropriate for panels with few time periods relative to the number of units. This is clearly not the case for the annual data - in this case, including year fixed effects, the number of instruments inevitably far exceeds the number of groups - so I show results for panels of from 5 to 20 years.

\footnotetext{
${ }^{35}$ The choice of statistical model for a panel with a binary dependent variable and unit and time fixed effects is not straightforward. Probit and (unconditional) logit with fixed effects are inconsistent because of the incidental parameters problem (Greene 2003). The conditional logit fixed effects model (CLFE; Chamberlain 1980), which I use elsewhere in the paper, is consistent. However, it requires dropping all units in which the dependent variable does not change. Here, that creates serious problems. Besides the loss of up to two thirds of the data, eliminating the "dogs that don't bark" in this case produces estimates of the effect of income that are biased upward: all autocracies that became rich without democratizing are automatically excluded. For instance, running CLFE on 5- and 10-year panels, I find a strong, significant effect of income on democratic transitions even in just the 1960-2000 period. These problems have prompted many researchers to use the linear probability model (estimated by OLS, despite the binary dependent variable) when unit fixed effects are important. For recent uses, see Besley and Reynal-Querol (2011), Boix (2011 Table 1, column 9); Acemoglu et al. (2009, Tables 1 and 2); Bruckner and Ciccione (2011); Pope and Schweitzer (2011). These articles were published in Econometrica, The American Economic Review, The American Political Science Review, and The Journal of Monetary Economics. This model is consistent under relatively weak assumptions (Wooldridge 2002, Chapter 15.2), although it has the disadvantage of sometimes predicting probabilities outside the $0-1$ range. I do the same here.
} 
Table A1: Income and democracy, alternative estimations

\begin{tabular}{|c|c|c|c|c|c|c|c|c|c|c|c|c|c|c|c|}
\hline \multirow[b]{3}{*}{ Type of panel: } & \multicolumn{5}{|c|}{ Level of democracy } & \multicolumn{5}{|c|}{ Transitions to democracy } & \multicolumn{5}{|c|}{ Transitions to democracy } \\
\hline & \multicolumn{5}{|c|}{$\begin{array}{l}\text { (A) } 1820-2008 ; \text { Polity } 2 t-1<6 \\
\text { No interpolated income values }\end{array}$} & \multicolumn{5}{|c|}{$\begin{array}{l}\text { (B) 1820-2008; Polity2 } t-1<6 \\
\text { Polity2: just upward movements }\end{array}$} & \multicolumn{5}{|c|}{$\begin{array}{l}\text { (C) 1820-2000; dichotomous Boix et al. } \\
\text { Just non-democracies }\end{array}$} \\
\hline & $1-y r$ & $5-y r$ & $10-y r$ & $15-y$ & $20-y r$ & $1-y r$ & $5-y r$ & $10-y r$ & $15-y r$ & $20-y r$ & $1-y r$ & $5-y r$ & $10-y r$ & $15-y r$ & $20-y r$ \\
\hline Polity2 t-1 & $\begin{array}{l}.91 * * * \\
(.01)\end{array}$ & $\begin{array}{l}.57 * * * \\
(.06)\end{array}$ & $\begin{array}{l}.21 * * \\
(.09)\end{array}$ & $\begin{array}{l}.16 \\
(.13)\end{array}$ & $\begin{array}{l}.05 \\
(.12)\end{array}$ & $\begin{array}{l}.98 * * * \\
(.01)\end{array}$ & $\begin{array}{l}.82 * * * \\
(.04)\end{array}$ & $\begin{array}{l}.61 * * * \\
(.06)\end{array}$ & $\begin{array}{l}.65^{* * *} * \\
(.07)\end{array}$ & $\begin{array}{l}.51 * * * \\
(.10)\end{array}$ & & & & & \\
\hline Ln GDP per cap. t-1 & $\begin{array}{l}-.00 \\
(.01)\end{array}$ & $\begin{array}{l}.03 \\
(.03)\end{array}$ & $\begin{array}{l}.13 * * * \\
(.05)\end{array}$ & $\begin{array}{l}.16^{* *} \\
(.07)\end{array}$ & $\begin{array}{l}.24 * * \\
(.12)\end{array}$ & $\begin{array}{l}-.00 \\
(.00)\end{array}$ & $\begin{array}{l}.03 \\
(.02)\end{array}$ & $\begin{array}{l}.10^{* * *} \\
(.03)\end{array}$ & $\begin{array}{l}.12 * * * \\
(.04)\end{array}$ & $\begin{array}{l}.13^{*} \\
(.08)\end{array}$ & $\begin{array}{l}.00 \\
(.01)\end{array}$ & $\begin{array}{l}.06^{* *} \\
(.03)\end{array}$ & $\begin{array}{l}.20 * * * \\
(.05)\end{array}$ & $\begin{array}{l}.22 * * * \\
(.07)\end{array}$ & $\begin{array}{l}.28 * * \\
(.12)\end{array}$ \\
\hline $\begin{array}{l}\text { Cumulative effect } \\
\text { of income }\end{array}$ & -.00 & .06 & $.17 * * *$ & $.19 * *$ & $.25 * *$ & -.00 & .16 & $.27 * * *$ & $.33 * *$ & $.27^{*}$ & & & & & \\
\hline $\begin{array}{l}\text { Fisher } \mathrm{p} \text { level } \\
\text { Observations } \\
\text { Countries } \\
\text { R-squared }\end{array}$ & $\begin{array}{l}{[.00]} \\
6,553 \\
140 \\
.8702\end{array}$ & $\begin{array}{l}{[.00]} \\
1,286 \\
137 \\
.6262\end{array}$ & $\begin{array}{l}{[.00]} \\
617 \\
123 \\
.5926\end{array}$ & $\begin{array}{l}{[.00]} \\
381 \\
123 \\
.6280\end{array}$ & $\begin{array}{l}{[.30]} \\
276 \\
115 \\
.7004\end{array}$ & $\begin{array}{l}{[.00]} \\
8,216 \\
140 \\
.9208\end{array}$ & $\begin{array}{l}{[.00]} \\
1,573 \\
137 \\
.7448\end{array}$ & $\begin{array}{l}{[.00]} \\
730 \\
123 \\
.6960\end{array}$ & $\begin{array}{l}{[.00]} \\
474 \\
123 \\
.7185\end{array}$ & $\begin{array}{l}{[.00]} \\
340 \\
116 \\
.7511\end{array}$ & $\begin{array}{l}{[.00]} \\
7,909 \\
142 \\
.0843\end{array}$ & $\begin{array}{l}{[.00]} \\
1,535 \\
139 \\
.2339\end{array}$ & $\begin{array}{l}{[.00]} \\
714 \\
128 \\
.4187\end{array}$ & $\begin{array}{l}{[.02]} \\
459 \\
126 \\
.5288\end{array}$ & $\begin{array}{l}{[.00]} \\
336 \\
120 \\
.6298\end{array}$ \\
\hline & \multicolumn{5}{|c|}{ (D) 1820-2008; Polity2 $t-1<10$} & \multicolumn{5}{|c|}{$\begin{array}{l}\text { (E) } 1820-2008 ; \text { Polity }{ }_{t-1}<6 \\
\text { Honoré Two Side Estimator }\end{array}$} & \multicolumn{5}{|c|}{$\begin{array}{c}\text { (F) 1820-2008; Polity } 2_{t-1}<6 \\
\text { Arellano-Bond GMM }\end{array}$} \\
\hline Type of panel: & $1-y r$ & $5-y r$ & $10-y r$ & $15-y r$ & $20-y r$ & $1-y r$ & $5-y r$ & $10-y r$ & $15-y r$ & $20-y r$ & $5-y r$ & $10-y r$ & $15-y r$ & $20-y r$ & \\
\hline Polity2 t-1 & $\begin{array}{l}.91 * * * \\
(.01)\end{array}$ & $\begin{array}{l}.60 * * * \\
(.04)\end{array}$ & $\begin{array}{l}.26 * * * \\
(.06)\end{array}$ & $\begin{array}{l}.17 * * \\
(.08)\end{array}$ & $\begin{array}{l}-.07 \\
(.07)\end{array}$ & $\begin{array}{l}.98 * * * \\
(.00)\end{array}$ & $\begin{array}{l}.83 * * * \\
(.02)\end{array}$ & $\begin{array}{l}.38 * * * \\
(.07)\end{array}$ & $\begin{array}{l}.30 * * * \\
(.07)\end{array}$ & $\begin{array}{l}.04 \\
(.09)\end{array}$ & $\begin{array}{l}.19 * * \\
(.08)\end{array}$ & $\begin{array}{l}-.17 \\
(.11)\end{array}$ & $\begin{array}{l}-.08 \\
(.15)\end{array}$ & $\begin{array}{l}.00 \\
(.14)\end{array}$ & \\
\hline Ln GDP per cap. $\mathrm{t}-1$ & $\begin{array}{l}.00 \\
(.00)\end{array}$ & $\begin{array}{l}.03 * \\
(.02)\end{array}$ & $\begin{array}{l}.11^{* * *} \\
(.04)\end{array}$ & $\begin{array}{l}.13 * * \\
(.05)\end{array}$ & $\begin{array}{l}.21 * * * \\
(.08)\end{array}$ & $\begin{array}{l}.014 * * * \\
(.002)\end{array}$ & $\begin{array}{l}.08 * * * \\
(.01)\end{array}$ & $\begin{array}{l}.19 * * * \\
(.04)\end{array}$ & $\begin{array}{l}.22 * * * \\
(.05)\end{array}$ & $\begin{array}{l}.34 * * * \\
(.09)\end{array}$ & $\begin{array}{l}.26 * * \\
(.13)\end{array}$ & $\begin{array}{l}.98 * * * \\
(.21)\end{array}$ & $\begin{array}{l}.82 * * * \\
(.25)\end{array}$ & $\begin{array}{l}.86 * * * \\
(.27)\end{array}$ & \\
\hline $\begin{array}{l}\text { Cumulative effect } \\
\text { of income }\end{array}$ & .04 & $.08^{*}$ & $.15 * * *$ & $.16^{* *}$ & $.20 * * *$ & & & & & & $.32 * *$ & $.83 * * *$ & $.76 * * *$ & $.86 * * *$ & \\
\hline $\begin{array}{l}\text { Fisher p level } \\
\operatorname{AR}(2) \text { test } \\
\text { Hansen J-test }\end{array}$ & {$[.00]$} & {$[.00]$} & {$[.00]$} & {$[.00]$} & {$[.01]$} & & & & & & $\begin{array}{l}{[.45]} \\
{[.54]}\end{array}$ & $\begin{array}{l}{[.87]} \\
{[.47]}\end{array}$ & $\begin{array}{l}{[.27]} \\
{[.19]}\end{array}$ & $\begin{array}{l}{[.43]} \\
{[.29]}\end{array}$ & \\
\hline Observations & 10,048 & 1,877 & 849 & 539 & 394 & 12,054 & 2,232 & 1000 & 631 & 457 & 1,440 & 610 & 355 & 227 & \\
\hline $\begin{array}{l}\text { Countries } \\
\text { R-squared }\end{array}$ & $\begin{array}{l}157 \\
.9345\end{array}$ & $\begin{array}{l}153 \\
.7459\end{array}$ & $\begin{array}{l}133 \\
.6518\end{array}$ & $\begin{array}{l}132 \\
.6608\end{array}$ & $\begin{array}{l}128 \\
.6997\end{array}$ & 161 & 158 & 134 & 121 & 99 & 135 & 120 & 107 & 84 & \\
\hline
\end{tabular}

Sources: see Table A18.

Note: (A)-(D) estimated by OLS with country and year fixed effects; " $t-1$ " refers to previous panel period. Robust standard errors, clustered by country, in parentheses; * $\mathrm{p}<.10, * * \mathrm{p}<.05, * * * \mathrm{p}<.01$. "Fisher $\mathrm{p}$ level": probability level at which one can reject H0: residuals are I(1), from Fisher test of residuals. Cumulative effects calculated as on p.1. (E): Year fixed effects included in 10-20 year panels; could not compute with year fixed effects in 1 and 5 year panels. (F): Arellano-Bond regressions, democracy and Ln GDP per capita instrumented with second lags. 
Table A2 shows that results are similar to those in Table 2, panel C, if one focuses on transitions to democracy (using the Boix-Miller-Rosato dichotomous measure or just upward movements on the Polity 2 scale, as in Table A1) or excludes interpolated income data. On use of linear probability model in (A), see note to Table A1.

Table A2: Income, leadership change, and democracy—alternative estimations

\begin{tabular}{|c|c|c|c|c|c|c|c|c|c|c|c|c|c|c|c|c|c|c|}
\hline \multirow{4}{*}{ Type of panel: } & \multicolumn{12}{|c|}{ - } & \multicolumn{6}{|c|}{--------Level of Democracy-------- } \\
\hline & \multicolumn{6}{|c|}{$\begin{array}{l}\text { (A) 1875-2004:BMR binary measure, } \\
\text { only non-democracies }\end{array}$} & \multicolumn{6}{|c|}{$\begin{array}{l}\text { (B) 1875-2004: Polity, Polity } 2_{t-1}<6 \text {, } \\
\text { just upward movements }\end{array}$} & \multicolumn{6}{|c|}{$\begin{array}{l}\text { (C) 1875-2004: Polity, Polity } 2_{t-1}<6 \text {, } \\
\text { no interpolated income values }\end{array}$} \\
\hline & $1-y r$ & $5-y r$ & $10-y r$ & $15-y r$ & $20-y r$ & $10-y r$ & $1-y r$ & $5-y r$ & $10-y r$ & $15-y r$ & $20-y r$ & $10-y r$ & $1-y r$ & $5-y r$ & $10-y r$ & $15-y r$ & $20-y r$ & $10-y r$ \\
\hline & (1) & (2) & (3) & (4) & (5) & (6) & (7) & (8) & (9) & (10) & (11) & (12) & (13) & (14) & (15) & $(16)$ & (17) & (18) \\
\hline Democracy $\mathrm{t}-1$ & & & & & & & $\begin{array}{l}.98 * * * \\
.01)\end{array}$ & $\begin{array}{l}.76^{* * * *} \\
(.05)\end{array}$ & $\begin{array}{l}.53 * * * \\
(.07)\end{array}$ & $\begin{array}{l}.56 * * * \\
(.08)\end{array}$ & $\begin{array}{l}.39 * * * \\
(.10)\end{array}$ & $\begin{array}{l}.58 * * * \\
(.07)\end{array}$ & $\begin{array}{l}.90 * * * \\
(.01)\end{array}$ & $\begin{array}{l}.50 * * * \\
(.07)\end{array}$ & $\begin{array}{l}.11 \\
(.10)\end{array}$ & $\begin{array}{l}.02 \\
(.15)\end{array}$ & $\begin{array}{l}-.09 \\
(.13)\end{array}$ & $\begin{array}{l}.28 * * \\
(.11)\end{array}$ \\
\hline $\begin{array}{l}\text { Leader replaced in } \\
\text { previous period }\end{array}$ & $\begin{array}{l}-.21 * * \\
(.08)\end{array}$ & $\begin{array}{l}-.77 * * * \\
(.22)\end{array}$ & $\begin{array}{l}-.84 * * \\
(.34)\end{array}$ & $\begin{array}{l}-1.98^{* * * *} \\
(.47)\end{array}$ & $\begin{array}{l}-2.06^{* * * *} \\
(.62)\end{array}$ & $\begin{array}{l}-.06 \\
(.06)\end{array}$ & $\begin{array}{l}-.07 * * \\
(.04)\end{array}$ & $\begin{array}{l}-.26 * * \\
(.12)\end{array}$ & $\begin{array}{l}-.63^{* *} \\
(.25)\end{array}$ & $\begin{array}{l}-1.03 * * * \\
(.35)\end{array}$ & $\begin{array}{l}-.87 \\
(.57)\end{array}$ & $\begin{array}{l}.03 \\
(.05)\end{array}$ & $\begin{array}{l}-.07 * \\
(.04)\end{array}$ & $\begin{array}{l}-.27 * \\
(.14)\end{array}$ & $\begin{array}{l}-.59 * * \\
(.28)\end{array}$ & $\begin{array}{l}-1.08^{* *} \\
(.46)\end{array}$ & $\begin{array}{l}-.71 \\
(.79)\end{array}$ & $\begin{array}{l}.05 \\
(.05)\end{array}$ \\
\hline Ln GDP per capita $t-1$ & $\begin{array}{l}-.00 \\
(.01)\end{array}$ & $\begin{array}{l}.01 \\
(.03)\end{array}$ & $\begin{array}{l}.10 \\
(.06)\end{array}$ & $\begin{array}{l}-.06 \\
(.08)\end{array}$ & $\begin{array}{l}.01 \\
(.14)\end{array}$ & & $\begin{array}{l}-.00 \\
(.00)\end{array}$ & $\begin{array}{l}.01 \\
(.02)\end{array}$ & $\begin{array}{l}.02 \\
(.04)\end{array}$ & $\begin{array}{l}-.05 \\
(.05)\end{array}$ & $\begin{array}{l}-.01 \\
(.10)\end{array}$ & & $\begin{array}{l}-.00 \\
(.01)\end{array}$ & $\begin{array}{l}.01 \\
(.03)\end{array}$ & $\begin{array}{l}.05 \\
(.05)\end{array}$ & $\begin{array}{l}-.04 \\
(.08)\end{array}$ & $\begin{array}{l}.11 \\
(.15)\end{array}$ & \\
\hline $\begin{array}{l}\text { Ln GDP per capita } t-1 * \\
\text { leader replaced prev. per. }\end{array}$ & $\begin{array}{l}.03 * * * \\
(.01)\end{array}$ & $\begin{array}{l}.11 * * * \\
(.03)\end{array}$ & $\begin{array}{l}.12 * * \\
(.05)\end{array}$ & $\begin{array}{l}.28 * * * \\
(.06)\end{array}$ & $\begin{array}{l}.30 * * * \\
(.08)\end{array}$ & & $\begin{array}{l}.012 * * \\
(.005)\end{array}$ & $\begin{array}{l}.04 * * \\
(.02)\end{array}$ & $\begin{array}{l}.10 * * * \\
(.03)\end{array}$ & $\begin{array}{l}.16^{* * *} \\
(.05)\end{array}$ & $\begin{array}{l}.14^{*} \\
(.08)\end{array}$ & & $\begin{array}{l}.011^{*} \\
(.006)\end{array}$ & $\begin{array}{l}.04 * * \\
(.02)\end{array}$ & $\begin{array}{l}.09 * * \\
(.04)\end{array}$ & $\begin{array}{l}.17 * * * \\
(.06)\end{array}$ & $\begin{array}{l}.12 \\
(.10)\end{array}$ & \\
\hline $\begin{array}{l}\text { Average yrs schooling } \\
\text { (age } 15 \text { and over) } t-1\end{array}$ & & & & & & $\begin{array}{l}.02 \\
(.03)\end{array}$ & & & & & & $\begin{array}{l}.02 \\
(.02)\end{array}$ & & & & & & $\begin{array}{l}.02 \\
(.03)\end{array}$ \\
\hline $\begin{array}{l}\text { Average yrs schooling } \mathrm{t}_{-1} * \\
\text { leader replaced prev. per. }\end{array}$ & & & & & & $\begin{array}{l}.06 * * * \\
(.02)\end{array}$ & & & & & & $\begin{array}{l}.03 * * \\
(.02)\end{array}$ & & & & & & $\begin{array}{l}.03 * * \\
(.02)\end{array}$ \\
\hline \multicolumn{19}{|l|}{$\begin{array}{l}\text { Cumulative } \\
\text { effect of income }\end{array}$} \\
\hline -if leader replaced & $.03 * *$ & $.12 * * *$ & $.21 * * *$ & $.22 * * *$ & $.30 * *$ & & .42 & $.20 *$ & $.25 * *$ & $.26 * *$ & $.21^{*}$ & & .09 & $.11 *$ & $.17 * *$ & .13 & $.21^{*}$ & \\
\hline $\begin{array}{l}\text {-if leader not replaced } \\
\text { Cumulative } \\
\text { effect of schooling }\end{array}$ & -.00 & .01 & .10 & -.06 & .01 & & -.13 & .03 & .05 & -.11 & -.02 & & -.02 & .03 & .06 & -.04 & .10 & \\
\hline $\begin{array}{l}\text {-if leader replaced } \\
\text {-if leader not replaced }\end{array}$ & & & & & & $\begin{array}{l}.08 * * \\
.02\end{array}$ & & & & & & $\begin{array}{l}.14 * * \\
.06\end{array}$ & & & & & & $\begin{array}{l}.07 * \\
.02\end{array}$ \\
\hline Fisher $\mathrm{p}$ level & {$[.00]$} & {$[.00]$} & {$[.00]$} & {$[.23]$} & {$[.00]$} & {$[.00]$} & {$[.00]$} & {$[.00]$} & {$[.00]$} & {$[.00]$} & {$[.00]$} & {$[.00]$} & {$[.00]$} & {$[.00]$} & {$[.00]$} & {$[.77]$} & {$[.83]$} & {$[.00]$} \\
\hline Observations & 6,221 & 1,191 & 583 & 383 & 287 & 399 & 6,425 & 1,233 & 601 & 396 & 291 & 416 & 5,676 & 1,094 & 547 & 336 & 246 & 416 \\
\hline Countries & 136 & 133 & 122 & 121 & 115 & 64 & 134 & 132 & 119 & 120 & 113 & 65 & 134 & 132 & 119 & 120 & 113 & 65 \\
\hline R-squared & .0968 & .2756 & .4497 & .5751 & .6682 & .4188 & .9128 & .7298 & .7099 & .7537 & .7871 & .6842 & .8644 & .6174 & .6154 & .6920 & .7521 & .5569 \\
\hline
\end{tabular}

Sources: see Table A18.

Note: All regressions estimated by OLS with country and year fixed effects; " $t-1$ " refers to previous panel period. Robust standard errors, clustered by country, in parentheses; ${ }^{*} \mathrm{p}<.10, * * \mathrm{p}<.05, * * * \mathrm{p}<.01$. "Fisher $\mathrm{p}$ level": probability level at which one can reject H0: residuals are I(1), from Fisher test of residuals. Cumulative effects calculated as on p.1. 
OLS with fixed effects and a lagged dependent variable can yield biased estimates because the lagged dependent variable is mechanically correlated with the error terms for earlier periods. Table A3 shows results are also similar if the lagged dependent variable is dropped (at the cost of autocorrelation and less precise estimates; clustered standard errors, nevertheless, remain consistent).

Table A3: Income, leadership change, and democracy—without the lagged dependent variable

Level of Democracy

\begin{tabular}{|c|c|c|c|c|c|c|}
\hline \multirow[b]{3}{*}{ Type of panel: } & \multicolumn{5}{|c|}{ Level of Democracy } & \multirow[b]{3}{*}{$10-y r$} \\
\hline & \multicolumn{5}{|c|}{ 1875-2004: Polity, Polity $2_{t-1}<6$} & \\
\hline & $1-y r$ & $5-y r$ & $10-y r$ & $15-y r$ & $20-y r$ & \\
\hline & $(1)$ & $(2)$ & (3) & $(4)$ & $(5)$ & $(6)$ \\
\hline $\begin{array}{l}\text { Leader replaced in } \\
\text { previous period }\end{array}$ & $\begin{array}{l}.03 \\
(.08)\end{array}$ & $\begin{array}{l}-.22 \\
(.14)\end{array}$ & $\begin{array}{l}-.62 * * \\
(.26)\end{array}$ & $\begin{array}{l}-1.05^{* * *} \\
(.36)\end{array}$ & $\begin{array}{l}-.84 \\
(.57)\end{array}$ & $\begin{array}{l}.08 \\
(.05)\end{array}$ \\
\hline Ln GDP per capita $\mathrm{t}-1$ & $\begin{array}{l}.00 \\
(.02)\end{array}$ & $\begin{array}{l}.03 \\
(.03)\end{array}$ & $\begin{array}{l}.05 \\
(.05)\end{array}$ & $\begin{array}{l}-.03 \\
(.06)\end{array}$ & $\begin{array}{l}.09 \\
(.11)\end{array}$ & \\
\hline $\begin{array}{l}\text { Ln GDP per capita } \mathrm{t}-1 * \\
\text { leader replaced previous period }\end{array}$ & $\begin{array}{l}.004 \\
(.011)\end{array}$ & $\begin{array}{l}.04 * * \\
(.02)\end{array}$ & $\begin{array}{l}.10^{* * *} \\
(.04)\end{array}$ & $\begin{array}{l}.16^{* * *} \\
(.05)\end{array}$ & $\begin{array}{l}.13^{*} \\
(.08)\end{array}$ & \\
\hline $\begin{array}{l}\text { Average yrs of schooling } \\
\text { (age } 15 \text { and over) } t-1\end{array}$ & & & & & & $\begin{array}{l}.02 \\
(.04)\end{array}$ \\
\hline $\begin{array}{l}\text { Average yrs schooling }{ }_{t-1} * \\
\text { leader replaced previous period }\end{array}$ & & & & & & $\begin{array}{l}.03^{*} \\
(.02)\end{array}$ \\
\hline $\begin{array}{l}\text { Cumulative } \\
\text { effect of income }\end{array}$ & & & & & & \\
\hline if leader replaced & .007 & $.07 * *$ & $.15^{* * *}$ & $.14 * *$ & $.22 * *$ & \\
\hline if leader not replaced & .002 & .03 & .05 & -.03 & .09 & \\
\hline $\begin{array}{l}\text { Cumulative } \\
\text { effect of schooling } \\
\text { if leader replaced } \\
\text { if leader not replaced }\end{array}$ & & & & & & $\begin{array}{l}.05 \\
.02\end{array}$ \\
\hline Fisher $\mathrm{p}$ level & {$[.00]$} & {$[.00]$} & {$[.00]$} & {$[.00]$} & {$[.86]$} & {$[.00]$} \\
\hline Observations & 6,425 & 1,233 & 601 & 396 & 291 & 416 \\
\hline Countries & 134 & 132 & 119 & 120 & 113 & 65 \\
\hline R-squared & .5134 & .5368 & .5972 & .6719 & .7342 & .5346 \\
\hline
\end{tabular}

Sources: see Table A18.

Note: All regressions estimated by OLS with country and year fixed effects; " $t-l$ " refers to previous panel period. Robust standard errors, clustered by

country, in parentheses; $* \mathrm{p}<.10, * * \mathrm{p}<.05, * * * \mathrm{p}<.01$. "Fisher $\mathrm{p}$ level": probability level at which one can reject H0: residuals are I(1), from Fisher test of residuals. Cumulative effects calculated as on p.1. 
Figure A1A: Predicted increase in democracy after ten years, with and without prior leader change, non-democracies, 1875-2004

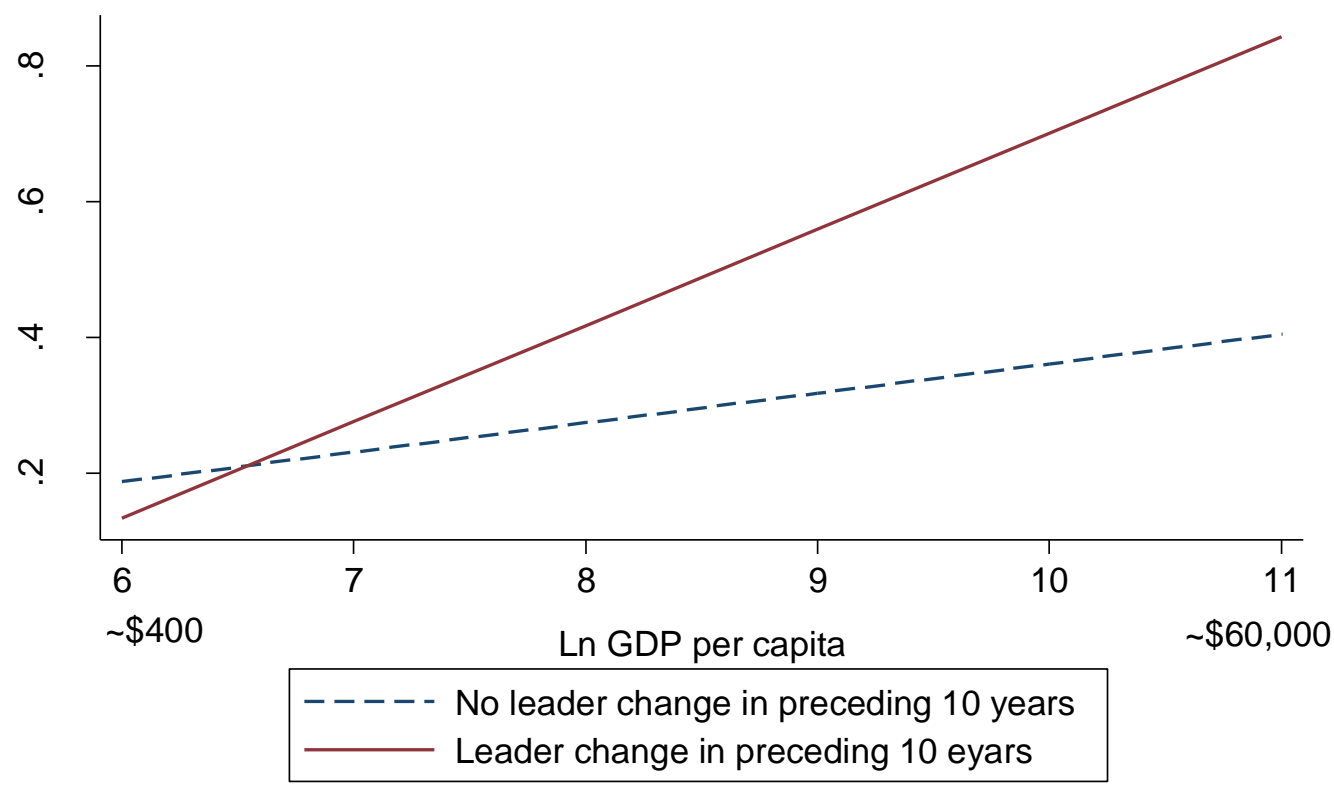

Source: See Table A18; calculated from Table 2, model 13 (10-year panel).

Figure A1B: Difference in predicted increase in democracy after ten years, with prior leader change compared to without, non-democracies, 1875-2004

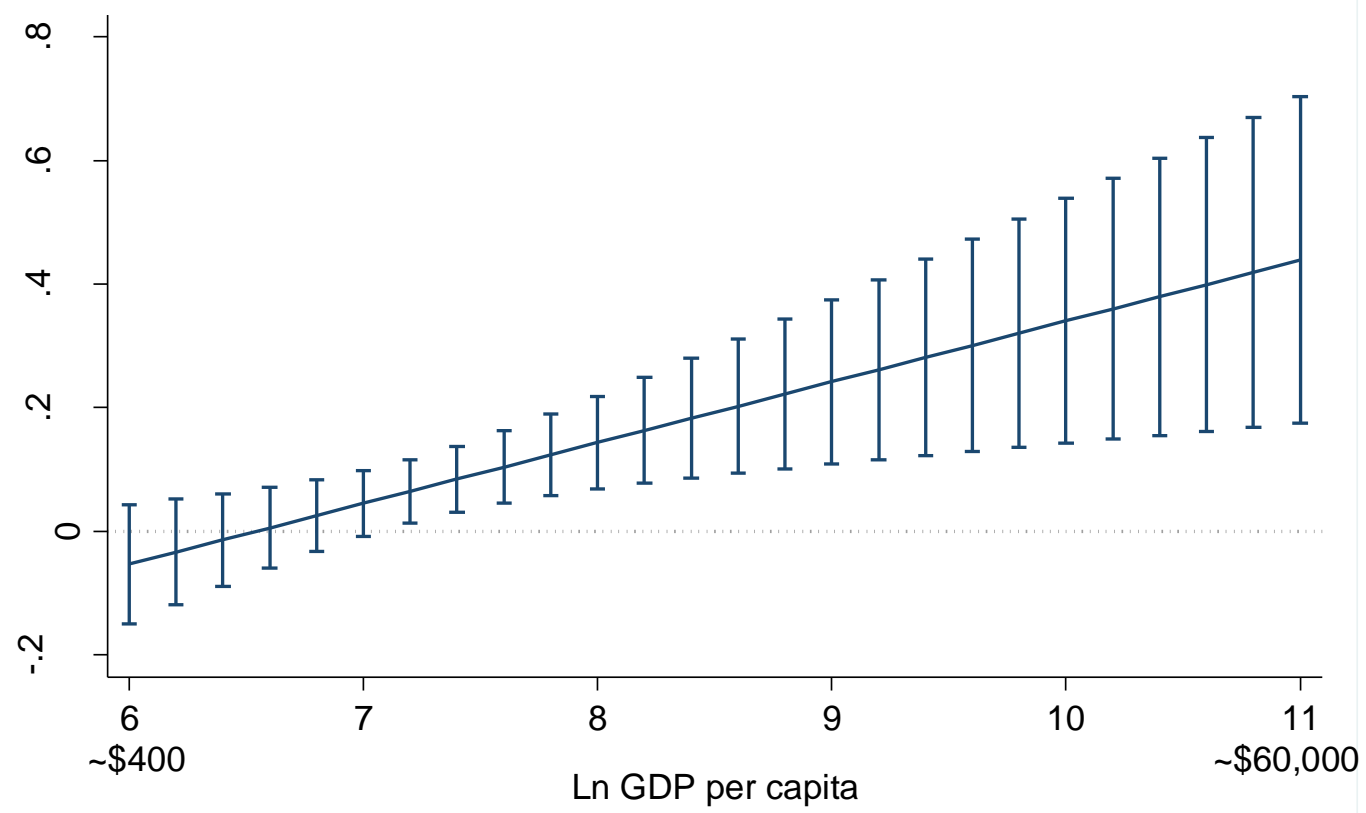

Source: See Table A18; calculated from Table 2, model 13 (10-year panel); 95 percent confidence intervals 


\section{Estimating the relationship with a panel error correction model}

I argue that there is an equilibrium relationship between income and democracy, but that reequilibration occurs only in periods after leader turnover. Thus, the system alternates between two states that depend on whether turnover has recently occurred. One can capture this with the following model, estimated on annual data:

$$
\Delta d_{i t}=l_{t-1}\left(\alpha d_{i t-1}+\phi y_{i t-1}+\gamma \Delta y_{i t}+\mu_{t}+\delta_{i}+1\right)+\left(1-l_{t-1}\right)\left(\eta d_{i t-1}+\kappa y_{i t-1}+\lambda \Delta y_{i t}+\theta_{t}+\psi_{i}\right)+u_{i t}
$$

where $l_{t}$ is a dummy coded 1 in years when the leader exited, 0 otherwise. The first part of the right-hand side models the dynamics in years after leader exit, the second part captures those in other years. If the estimates for $\alpha$ and $\phi$ are significant and have opposite signs, that suggests there is a positive equilibrium relationship between income and democracy that is visible in periods after leader turnover. From this, we can derive the speed at which equilibration occurs during the post-turnover period. Note that we do not expect $\eta$ and $\kappa$ to both be significant (there is no equilibrium relationship detectable in years when leader exit has not occurred). Nor do we expect the coefficients on the growth terms, $\gamma$ and $\lambda$, necessarily to be significant-although they may — because of the opposite effects growth has, simultaneously raising the income level (favoring democracy) and entrenching the incumbent (obstructing change). I allow the fixed effects to differ between the two types of period.

In Table A4, I show results for this model. As expected, lagged income and democracy are significant, with opposite signs, in the case of leader exit. This suggests an equilibrium relationship between the two such that a one $\ln$ unit increase in income is associated with around a .26 points increase in the rescaled Polity2 score (or equivalently, a doubling of GDP per capita is associated with a .17 point Polity2 increase). ${ }^{36}$ I graph the equilibrium relationship in Figure A2. In the noexit years, only lagged democracy is significant (with a negative coefficient), suggesting reversion to the mean, but no impact of income. The growth rate is not significant at all if the leader did not exit. If he did exit, it is significant at $p<.10$, with a positive sign.

\footnotetext{
${ }^{36}$ The long run multiplier between $\operatorname{Ln}$ income and democracy is equal to $-\phi / \alpha$.
} 
Table A4: Income, leadership change, and democracy — estimated with a panel error correction model

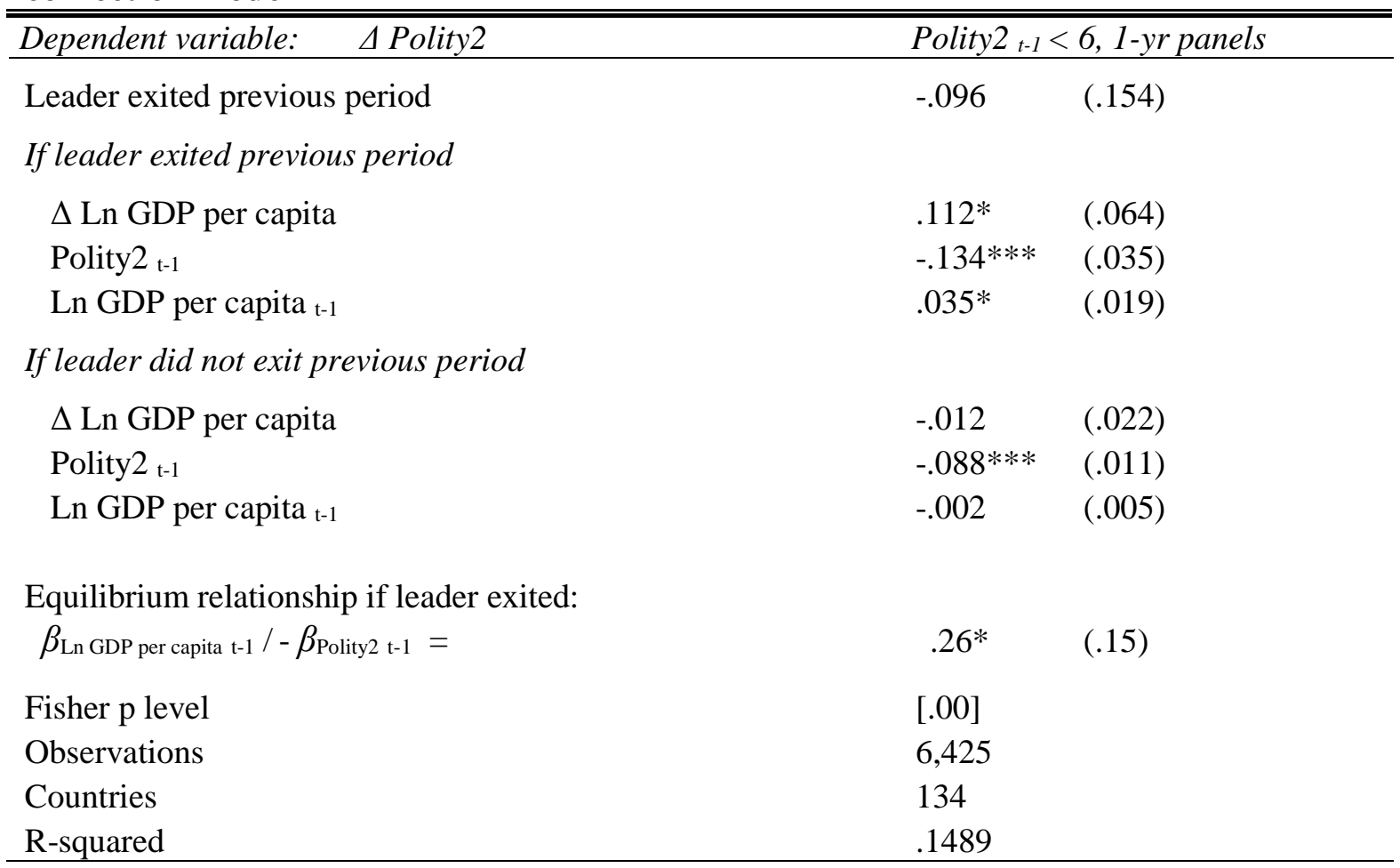

Sources: see Table A18.

Note: Estimated by OLS with full sets of country and year fixed effects, interacted with indicator for leader turnover in previous year. Robust standard errors, clustered by country, in parentheses; $* \mathrm{p}<.10, * * \mathrm{p}<.05, * * * \mathrm{p}$ $<.01$. "Fisher p level": probability level at which one can reject H0: residuals are I(1), from Fisher test of residuals.

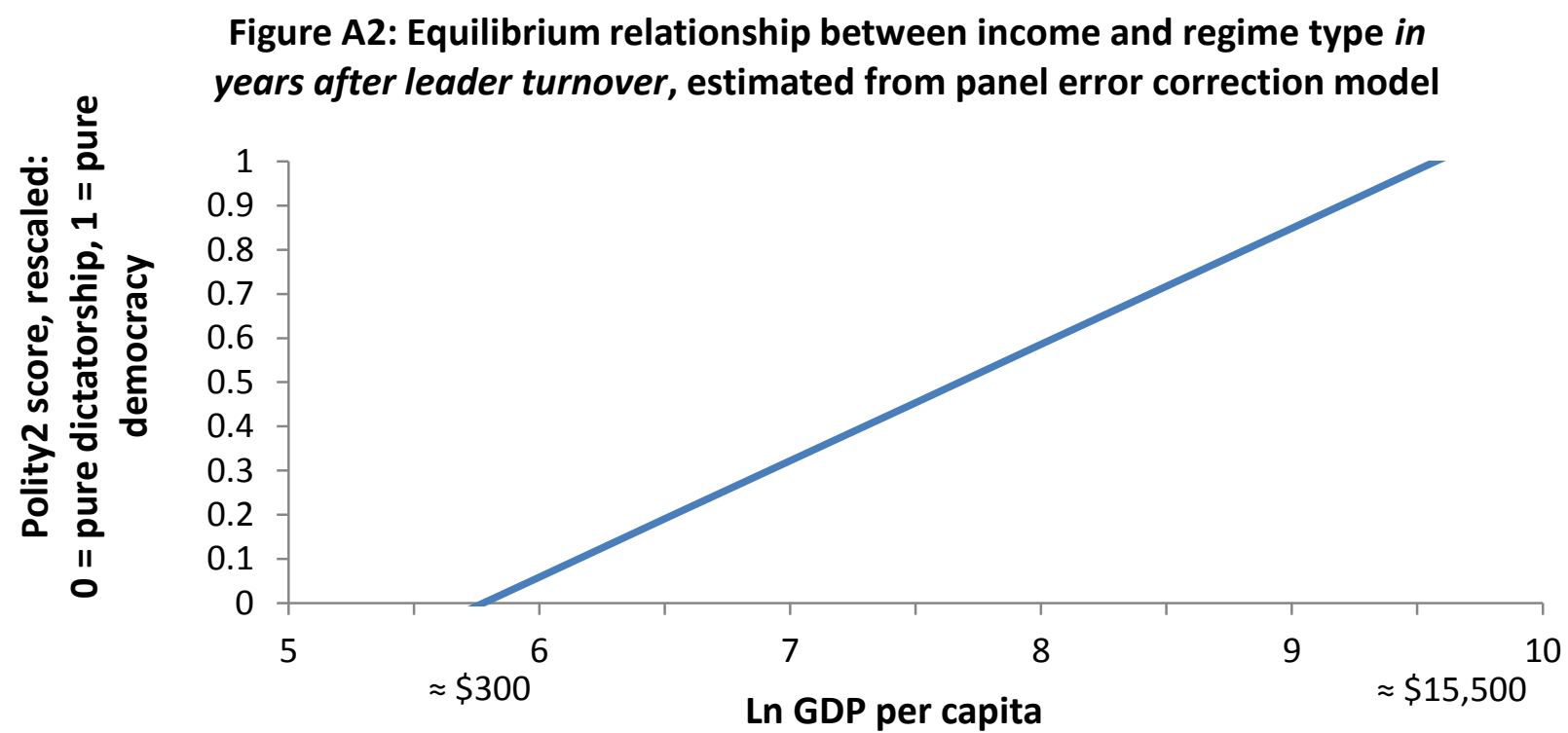

Source: See Table A18.

Note: Equilibrium equation: -.134Democracy $\mathrm{t}_{\mathrm{t}-1}+.035 \mathrm{Ln}$ GDP per capita $\mathrm{t}_{\mathrm{t}-1}-.096-.108=0 .(-.108=$ average of fixed effects for countries and years plus constant.) No equilibrium relationship in periods without leader change. 


\section{Other possible estimation strategies}

Another approach would be to use annual data and estimate the effect of income conditional on leader turnover over multiyear periods by including multiple lags of income, leader turnover, and their interaction:

$$
d_{i t}=\sum_{j=1}^{k}\left(\gamma_{i t-j} y_{i t-j}+\phi_{i t-j} l_{i t-j} y_{i t-j}+\eta_{i t-j} l_{i t-j}\right)+\alpha d_{i t-k}+\mu_{t}+\delta_{i}+u_{i t}
$$

where $l_{i t}$ is a dummy taking the value 1 if leader turnover occurred in period $t$. There are two problems with this. Most important, the argument in this paper contrasts the effect of income during $k$-year periods in which at least one leader turnover occurred with the effect of income in $k$-year periods in which the same leader remained in power throughout. However, A2 does not estimate this. Instead, it estimates the effect of income if leader turnover occurred in precisely year $t$ - $k$ (while controlling for income and leader turnover in the intervening years of the $k$-year period). And it is not obvious how one could recover the effect of income given at least one leader turnover from the regression results. The most direct way to estimate the effect of at least one leader turnover is to use a dummy for at least one leader turnover, as in Equation 1 in the paper and adjust so as to avoid attributing increases in Polity2 to leader turnover that did not precede the regime change. The second problem is that, even if one could recover the relevant effect, the high correlation between consecutive lags of $y_{i t}$ and $l_{i t} y_{i t}$ would produce severe multicollinearity, resulting in imprecise estimates.

One might also think of estimating versions of A2 with the intervening lags dropped:

$$
d_{i t}=\gamma_{i t-k} y_{i t-k}+\phi_{i t-k} l_{i t-k} y_{i t-k}+\eta_{i t-k} l_{i t-k}+\alpha d_{i t-k}+\mu_{t}+\delta_{i}+u_{i t}
$$

However, again, this would not estimate the effect of income conditional on at least one leader change. In addition, the estimates of $\gamma_{i t-k}$ and $\phi_{i t-k}$ would suffer from omitted variable bias because of the omission of the intervening lags.

Finally, one might estimate:

$$
\begin{gathered}
d_{i t}=\gamma_{i t-k} y_{i t-k}+\phi_{i t-k} \Lambda_{i t-k} y_{i t-k}+\eta_{i t-k} \Lambda_{i t-k}+\alpha d_{i t-k}+\mu_{t}+\delta_{i}+u_{i t} \\
\text { where } \Lambda_{i t-k}=\left\{\begin{array}{l}
1 \text { if } \sum_{j=1}^{k} l_{i t-j} \geq 1 \\
0 \text { if } \sum_{j=1}^{k} l_{i t-j}=0
\end{array}\right.
\end{gathered}
$$

that is using a dummy for whether there was at least one leader turnover in the $k$-year period. (One must now adjust to avoid picking up any relationship between increases in Polity2 and simultaneous or subsequent leader turnover.) This is quite close to the Equation 1 model estimated in the paper. Running such regressions, I get significant results for the interaction between income and leader turnover at all values of $k$, consistent with the paper's message. The main disadvantage of A4 is that it counts each instance of leader turnover multiple times (for $k=$ 20 , each leader turnover will show up in 20 consecutive values of $\Lambda_{i t-k}$ ). Thus, the errors will- 
by construction - be strongly autocorrelated since consecutive values of $\Lambda_{i t-k}$ will contain a lot of the same information (not to mention the high autocorrelation in income). For $k=20$, the correlation between $u_{i t}$ and $u_{i t-1}$ resulting from regressing A4 on this paper's dataset is $\mathrm{r}=.92$. Clustering the standard errors by country adjusts for this. Still, it seems preferable to choose an estimation strategy in which autocorrelation is less extreme.

Unlike A4, the formulation in Equation 1 does not include overlapping indicators of leader turnover. Each leader change is counted only once. Regressing Equation 1 on the 20-year data panel, the correlation between errors for consecutive country periods is only $r=.24$. 
A. Percent of cases with leader turnover within:

-1 year

-5 years

-10 years

-15 years

-20 years
14

48

66

77

85

17

21

13

15

14

14

19

$6,001-10,000$

$>10,000$

C. Percent of nondemocracies that

had higher Polity2 score

-1 year after leader turnover

-5 years after leader turnover

-10 years after leader turnover
28

77

92

96

97

39

39

27

31

33

26

27

Sources: See Table A18.

Notes: In panel A, proportions for states that remain authoritarian or democratic throughout whole period. 
Table A6 shows results are similar if one varies the starting year of the panel.

Table A6: Effect of changing starting year in panel on estimated effect of income conditional on leader turnover

\begin{tabular}{|c|c|c|c|c|c|c|c|c|c|c|}
\hline \multicolumn{11}{|c|}{ 5-Year Panel } \\
\hline Panel of years ending in: & 0 or 5 & 1 or 6 & 2 or 7 & 3 or 8 & 4 or 9 & & & & & \\
\hline $\begin{array}{l}\text { Coefficient on Ln GDP per } \\
\text { capita } t-1 * \text { leader exit prev. period }\end{array}$ & $\begin{array}{l}.04^{* *} \\
(.02)\end{array}$ & $\begin{array}{l}.04 * * \\
(.02)\end{array}$ & $\begin{array}{l}.05 * * * \\
(.02)\end{array}$ & $\begin{array}{l}.04 * * \\
(.02)\end{array}$ & $\begin{array}{l}.04 * * \\
(.02)\end{array}$ & & & & & \\
\hline \multicolumn{11}{|l|}{$\begin{array}{l}\text { Cumulative impact } \\
\text { of income }\end{array}$} \\
\hline \multirow{2}{*}{$\begin{array}{l}\text {-if leader replaced } \\
\text {-if leader not replaced }\end{array}$} & $.12 * *$ & $.12 * *$ & $.12 * * *$ & $.10 * *$ & $.10^{* *}$ & & & & & \\
\hline & .03 & .04 & .02 & .03 & .02 & & & & & \\
\hline \multicolumn{11}{|c|}{ 10-Year Panel } \\
\hline Panel of years ending in: & 0 & 1 & 2 & 3 & 4 & 5 & 6 & 7 & 8 & 9 \\
\hline $\begin{array}{l}\text { Coefficient on Ln GDP per } \\
\text { capita }_{t-1} * \text { leader exit prev. period }\end{array}$ & $\begin{array}{l}.10^{* * *} \\
(.03)\end{array}$ & $\begin{array}{l}.08 * * * \\
(.03)\end{array}$ & $\begin{array}{l}.10 * * * \\
(.03)\end{array}$ & $\begin{array}{l}.09 * * * \\
(.03)\end{array}$ & $\begin{array}{l}.10 * * * \\
(.03)\end{array}$ & $\begin{array}{l}.12 * * * \\
(.03)\end{array}$ & $\begin{array}{l}.08 * * \\
(.03)\end{array}$ & $\begin{array}{l}.09 * * * \\
(.03)\end{array}$ & $\begin{array}{l}.08^{* * *} \\
(.03)\end{array}$ & $\begin{array}{l}.07 * * \\
(.03)\end{array}$ \\
\hline \multicolumn{11}{|l|}{$\begin{array}{l}\text { Cumulative impact } \\
\text { of income }\end{array}$} \\
\hline \multirow{2}{*}{$\begin{array}{l}\text {-if leader replaced } \\
\text {-if leader not replaced }\end{array}$} & $.17 * * *$ & $.17 * * *$ & $.15 * * *$ & $.13 * *$ & $.10^{*}$ & $.10^{*}$ & $.09 *$ & $.11^{* *}$ & $.10 * *$ & $.14 * *$ \\
\hline & .05 & .07 & .03 & .02 & -.04 & -.06 & -.01 & .00 & .01 & .06 \\
\hline
\end{tabular}

Sources: see Table A18.

Notes: Robust standard errors, clustered by country, in parentheses; $* \mathrm{p}<.10, * * \mathrm{p}<.05, * * * \mathrm{p}<.01$. Estimates from regressions identical to those in Table 2 , column 12 (5-Year Panel) and column 13 (10-Year Panel). " $t-1$ " indicates previous panel period. 


\section{Miscellaneous issues}

Could it be that the Polity coders simply take leadership change as a sign of democratization? In this case, the association between leader exit and democratization would be trivial.

In fact, this is clearly not the case. Among the country-years for which the coders recorded an increase in the Polity 2 score, more than half (403) occurred with no leader change that year and 43 percent (311) occurred with no leader change either that year or the previous year. Conversely, of all country-years in which leader change occurred, only 15 percent were coded as years in which democracy increased. Evidently, the coders do not equate the two.

Are there too few cases of democratization without any prior leader change to estimate the relationship between income and democratization in such circumstances?

The proportion of cases of democratization without any prior leader change naturally falls as the panel interval increases. If the number fell too low, that could make it hard to estimate the effect of income in cases without leader turnover. This might explain why the significance of Ln GDP per capita is not higher in the 20-year panel (Table 2, column 15). Among non-democracies whose Polity2 score rose in a given year, only 11 percent (69 cases) had experienced no leader change in the preceding 20 years.

It is much less of an issue in the lower-interval panels. Among non-democracies whose Polity 2 score rose in a given year, 15 percent (98 cases) had experienced no leader change in the previous 15 years, 24 percent ( 155 cases) in the previous 10 years, 41 percent (262) in the previous 5 years, and 76 percent (552 cases) in the previous year. Without leader turnover, income is not just insignificant in the 20 -year panel-it is insignificant in all the others as well (Table 2, columns 11-14). 


\section{Robustness checks}

Table A7, column 1, repeats the basic model from Table 2, column 11, to facilitate comparison.

Whether a country democratizes may depend on the extent of democracy in other countries, especially those nearby (Gleditsch and Ward 2006, Gleditsch and Choung 2004). Column 2 controls for this using a measure of "foreign democratic capital"- essentially, the average level of democracy in other countries, weighted by their distanceconstructed by Persson and Tabellini (2009): $f_{i t}=\sum_{j \neq i}\left(1-a_{j t}\right) \varpi(\rho)_{t}^{i j}$, where $i$ and $j$ index countries, $t$ indexes year, $a$ equals 1 for autocracies and 0 for democracies, $\varpi^{i j}$ measures the distance between $i$ and $j$, and $\rho$ operationalizes a geographical limit beyond which influence falls to zero, which they, in fact, estimate from the data.

Column 3 controls for foreign trade as a share of GDP (Li and Reuveny 2003, Lopez-Cordova and Meissner 2008).

To capture the "resource curse," column 4 includes the logged income per capita earned from the country's sales of oil and gas, from Michael Ross's database.

Autocracies that use pseudo- or partly-democratic institutions such as elected legislatures and executive elections to coopt opposition may be more stable (Gandhi and Przeworski 2007), while non-regime parties may weaken the regime (Wright and Escribà-Folch 2012). Column 5 controls for these.

Column 6 includes whether the head of state was a military officer or a monarch, as recorded by Banks (2007). Column 7 uses the more fine-grained classifications of Geddes, Wright, and Frantz (2012: GWF), who distinguish military, monarchical, one-party, and personalistic regimes (but only since WWII). (I use "miscellaneous" for regimes that GWF do not consider non-democracies but which have a Polity2 score less than six; the excluded category is military regime.)

A country's history of democracy and autocracy may affect its current regime. In column 8, I include Persson and Tabellini's measure of accumulated democratic experience, which they call "domestic democratic capital." They assume this accrues at a fixed rate in each year a country is democratic (Polity2 >0) and depreciates geometrically in years of autocracy: $z_{i t}=(1-\delta) \sum_{\tau=0, \ldots, t_{0}}\left(1-a_{i t-\tau}\right) \delta^{\tau}$, where $i$ indexes countries, $t$ indexes year, $t_{0}$ is the initial year, $a$ equals 1 for autocracies and 0 for democracies, and $\delta$ is a discount rate that they estimate from the data. As a second check, column 9 contains a variable based on that used by Epstein et al. (2006) to capture the legacy of past democratic failures. Epstein et al. used the absolute value of the sum of a country's total downward movements on the Polity scale since 1960. I use the total since the start of the data, and normalize by the number of years.

To control for political instability, column 10 includes the percentage of previous leader changes in the country (since the start of the data) that were "irregular," according to the Archigos codings.

Perhaps it is not leader turnover that prompts democratization, but war that overthrows both leaders and regime. Column 11 controls for whether the country had been in a war or civil war the previous year, and whether the government won or lost such wars. (I exclude military defeats that resulted in foreign occupation or imposition of a leader, since obviously occupation by a democratic power could result in democracy.) Democratization was more likely if a civil war had been underway. But this had little effect on the leader turnover and income results.

In the same regressions run on 10-year panels (not shown), the interaction of income with leader change is sometimes less significant (probably due to the large drop in observations due to problems of data availability), but the cumulative impact of income after leader exit is almost always significant. 
Table A7: Robustness, one-year panel

\begin{tabular}{|c|c|c|c|c|c|c|c|c|}
\hline \multirow[t]{2}{*}{ Dependent variable: } & \multicolumn{8}{|c|}{ Polity 2 Level of Democracy, Polity ${ }_{t-1}<6,1-y$ r panels } \\
\hline & (1) & $(2)$ & (3) & (4) & (5) & (6) & $(7)$ & $(8)$ \\
\hline Polity $2 \mathrm{t}-1$ & $\begin{array}{l}.91 * * * \\
(.01)\end{array}$ & $\begin{array}{l}.91 * * * \\
(.01)\end{array}$ & $\begin{array}{l}.90 * * * \\
(.02)\end{array}$ & $\begin{array}{l}.89 * * * \\
(.01)\end{array}$ & $\begin{array}{l}.88 * * * \\
(.02)\end{array}$ & $\begin{array}{l}.91 * * * \\
(.01)\end{array}$ & $\begin{array}{l}.90 * * * \\
(.02)\end{array}$ & $\begin{array}{l}.92 * * * \\
(.01)\end{array}$ \\
\hline $\begin{array}{l}\text { Leader replaced in } \\
\text { previous period }\end{array}$ & $\begin{array}{l}-.08 * * \\
(.04)\end{array}$ & $\begin{array}{l}-.06^{*} \\
(.04)\end{array}$ & $\begin{array}{l}-.08^{*} \\
(.05)\end{array}$ & $\begin{array}{l}-.06 \\
(.04)\end{array}$ & $\begin{array}{l}-.09 * * \\
(.04)\end{array}$ & $\begin{array}{l}-.09 * * \\
(.04)\end{array}$ & $\begin{array}{l}-.08 \\
(.05)\end{array}$ & $\begin{array}{l}-.07 * \\
(.04)\end{array}$ \\
\hline Ln GDP per capita $\mathrm{t}-1$ & $\begin{array}{l}-.001 \\
(.005)\end{array}$ & $\begin{array}{l}.002 \\
(.005)\end{array}$ & $\begin{array}{l}.01 \\
(.01)\end{array}$ & $\begin{array}{l}-.003 \\
(.007)\end{array}$ & $\begin{array}{l}.002 \\
(.007)\end{array}$ & $\begin{array}{l}.000 \\
(.005)\end{array}$ & $\begin{array}{l}-.002 \\
(.007)\end{array}$ & $\begin{array}{l}.002 \\
(.005)\end{array}$ \\
\hline $\begin{array}{l}\text { Ln GDP per capita }{ }_{t-1} * \\
\text { leader replaced } t_{t-1}\end{array}$ & $\begin{array}{l}.012 * * \\
(.005)\end{array}$ & $\begin{array}{l}.010 * * \\
(.005)\end{array}$ & $\begin{array}{l}.013 * * \\
(.006)\end{array}$ & $\begin{array}{l}.011 * \\
(.006)\end{array}$ & $\begin{array}{l}.015^{* *} \\
(.006)\end{array}$ & $\begin{array}{l}.014 * * \\
(.005)\end{array}$ & $\begin{array}{l}.014 * * \\
(.007)\end{array}$ & $\begin{array}{l}.011 * * \\
(.005)\end{array}$ \\
\hline $\begin{array}{l}\text { Foreign democratic } \\
\text { capital }{ }_{t-1}\end{array}$ & & $\begin{array}{l}.10 \\
(.07)\end{array}$ & & & & & & \\
\hline Trade/GDP & & & $\begin{array}{l}-.011 * \\
(.007)\end{array}$ & & & & & \\
\hline $\begin{array}{l}\text { Log income from } \\
\text { oil and gas }\end{array}$ & & & & $\begin{array}{l}-.001 \\
(.002)\end{array}$ & & & & \\
\hline Non-regime parties & & & & & $\begin{array}{l}.007 \\
(.005)\end{array}$ & & & \\
\hline Elected legislature & & & & & $\begin{array}{l}-.014 * * \\
(.006)\end{array}$ & & & \\
\hline Elected executive & & & & & $\begin{array}{l}-.006 \\
(.006)\end{array}$ & & & \\
\hline Military regime $_{t-1}$ & & & & & & $\begin{array}{l}.023 * * \\
(.009)\end{array}$ & & \\
\hline Monarchy $t_{t-1}$ & & & & & & $\begin{array}{l}.011 \\
(.009)\end{array}$ & $\begin{array}{l}-.01 \\
(.01)\end{array}$ & \\
\hline One-party regime $_{t-1}$ & & & & & & & $\begin{array}{l}-.03 * * * \\
(.01)\end{array}$ & \\
\hline Personalistic regime $_{t-1}$ & & & & & & & $\begin{array}{l}-.03 * * * \\
(.01)\end{array}$ & \\
\hline Miscellaneous regime $_{t-1}$ & & & & & & & $\begin{array}{l}-.04 * * * \\
(.01)\end{array}$ & \\
\hline $\begin{array}{l}\text { Domestic democratic } \\
\text { capital } \mathrm{t}-1 \\
\text { Previous transitions }\end{array}$ & & & & & & & & $\begin{array}{l}-.05 * * * \\
(.02)\end{array}$ \\
\hline $\begin{array}{l}\text { Percent of previous } \\
\text { leader changes irregula }\end{array}$ & & & & & & & & \\
\hline $\begin{array}{l}\text { Cumulative effect } \\
\text { of income }\end{array}$ & & & & & & & & \\
\hline -if leader replaced & .12 & $.14^{*}$ & $.21 * *$ & .08 & $.14 *$ & $.16^{*}$ & .12 & $.16^{*}$ \\
\hline -if leader not replaced & -.01 & .02 & .09 & -.03 & .02 & .00 & -.02 & .03 \\
\hline Fisher $\mathrm{p}$ level & {$[.00]$} & {$[.00]$} & {$[.00]$} & {$[.00]$} & {$[.00]$} & {$[.00]$} & {$[.00]$} & {$[.00]$} \\
\hline Observations & 6,425 & 6,104 & 4,281 & 5,071 & 4,383 & 5,916 & 4,263 & 6,104 \\
\hline Countries & 134 & 130 & 123 & 127 & 123 & 132 & 119 & 130 \\
\hline R-squared & .8703 & .8691 & .8613 & .8594 & .8521 & .8718 & .8496 & .8697 \\
\hline
\end{tabular}


Table A7: (cont.)

\begin{tabular}{|c|c|c|c|}
\hline \multicolumn{4}{|c|}{ Dependent variable: Polity2 Level of Democracy, Polity2 ${ }_{t-1}<6,1-y r$ panel } \\
\hline & (9) & $(10)$ & $(11)$ \\
\hline Democracy $\mathrm{t}-1$ & $\begin{array}{l}.91 * * * \\
(.01)\end{array}$ & $\begin{array}{l}.91 * * * \\
(.01)\end{array}$ & $\begin{array}{l}.91 * * * \\
(.01)\end{array}$ \\
\hline $\begin{array}{l}\text { Leader replaced in } \\
\text { previous period }\end{array}$ & $\begin{array}{l}-.07 * \\
(.04)\end{array}$ & $\begin{array}{l}-.08 * * \\
(.04)\end{array}$ & $\begin{array}{l}-.08^{* *} \\
(.04)\end{array}$ \\
\hline Ln GDP per Capita $t-1$ & $\begin{array}{l}-.003 \\
(.005)\end{array}$ & $\begin{array}{l}-.001 \\
(.005)\end{array}$ & $\begin{array}{l}.000 \\
(.005)\end{array}$ \\
\hline $\begin{array}{l}\text { Ln GDP per Capita } t_{t-1} * \\
\text { leader replaced } t-1\end{array}$ & $\begin{array}{l}.012 * * \\
(.005)\end{array}$ & $\begin{array}{l}.012 * * \\
(.005)\end{array}$ & $\begin{array}{l}.012 * * \\
(.005)\end{array}$ \\
\hline Previous transitions & $\begin{array}{l}-.07 * * * \\
(.01)\end{array}$ & & \\
\hline $\begin{array}{l}\text { Percent of previous } \\
\text { leader changes irregular }\end{array}$ & & $\begin{array}{l}.001 \\
(.010)\end{array}$ & \\
\hline $\begin{array}{l}\text { Interstate war in } \\
\text { progress } \\
\mathrm{t}-1\end{array}$ & & & $\begin{array}{l}-.002 \\
(.007)\end{array}$ \\
\hline Won interstate war $\mathrm{t}-1$ & & & $\begin{array}{l}.004 \\
(.012)\end{array}$ \\
\hline Lost interstate war ${ }_{t-1}$ & & & $\begin{array}{l}.039 \\
(.025)\end{array}$ \\
\hline Civil war in progress $t-1$ & & & $\begin{array}{l}.021 * * * \\
(.007)\end{array}$ \\
\hline Government won civil war ${ }_{t-1}$ & & & $\begin{array}{l}-.018 \\
(.013)\end{array}$ \\
\hline Government lost civil war $\mathrm{t}-1$ & & & $\begin{array}{l}.013 \\
(.017)\end{array}$ \\
\hline $\begin{array}{l}\text { Cumulative } \\
\text { effect of income }\end{array}$ & & & \\
\hline -if leader replaced & .09 & .12 & .14 \\
\hline -if leader not replaced & -.03 & -.01 & .00 \\
\hline Fisher $\mathrm{p}$ level & {$[.00]$} & {$[.00]$} & {$[.00]$} \\
\hline Observations & 6,425 & 6,425 & 6,418 \\
\hline Countries & 134 & 134 & 134 \\
\hline R-squared & .8731 & .8703 & .8715 \\
\hline
\end{tabular}

Sources: see Table A18.

Note: All regressions estimated by OLS with country and year fixed effects. Robust standard errors, clustered by country, in parentheses; ${ }^{*} \mathrm{p}<.10,{ }^{* *} \mathrm{p}<.05,{ }^{* * *} \mathrm{p}<.01$. "Fisher $\mathrm{p}$ level": probability level at which one can reject $\mathrm{H} 0$ : residuals are I(1), from Fisher test of residuals. I assume that if a country enters the Ross data set with 0 oil and gas income, it also earned 0 income from oil and gas in preceding years. This reduces the loss of data due to fact that Ross data start only in 1930s. "Lost interstate war" excludes cases where foreign power occupied territory within following 10 years or imposed a leader. 


\section{Identification in Table 3}

While the timing of death by natural causes is unlikely to be affected by democratization, leader deaths in office may be more likely to occur in some settings than in others. We need to check that such contextual factors do not, in fact, account for the income-democracy relationship in the aftermath of a leader's natural death. Table A8 establishes that, among non-democracies, years in which a leader died of natural causes are distributed similarly to years without any leader death with regard to countries' income levels, Polity2 scores, and the time period. Such leader exits do occur slightly more often in South Asia and less often in Sub-Saharan Africa and Latin America than elsewhere. And, as one might expect, leaders that die in office tend to be older and to have served for longer. Table A9, therefore, repeats the top line of Table 3, but controlling for region of the world, (previous) leader's tenure, and (previous) leader's age.

Table A8: Characteristics of country/years in which leader died of natural causes, non-democracies, $1875-2004$

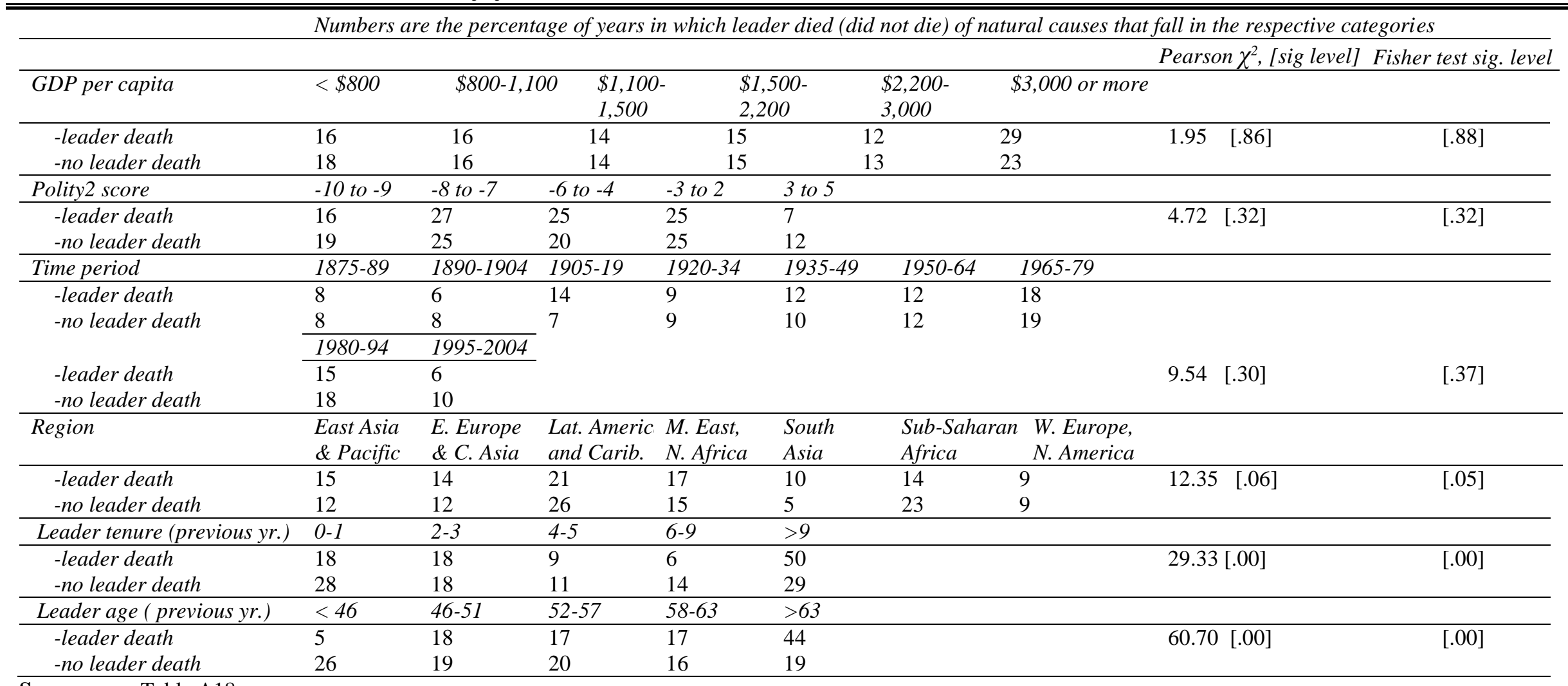

Sources: see Table A18. 
Table A9: Estimated marginal effect of income on increase in Polity 2 score in 10 years after dictator exited, with controls

\begin{tabular}{|c|c|c|c|}
\hline \multicolumn{4}{|c|}{ Figure is coefficient on lagged log GDP per capita in regression of the 10-year change in Polity2 (0 to1) } \\
\hline \multicolumn{4}{|c|}{ Controlling for region, tenure and age of deceased dictator } \\
\hline A) & After leader died of natural causes & $\begin{array}{l}\text { All 10-year periods in which leader } \\
\text { did not die of natural causes }\end{array}$ & $\begin{array}{l}\text { All 10-year periods in which } \\
\text { leader did not leave office }\end{array}$ \\
\hline & (1) & $(2)$ & (3) \\
\hline & $.22 * * *$ & $.16^{* * *}$ & $.03 * * *$ \\
\hline & $(.07)$ & $(.01)$ & $(.01)$ \\
\hline$N$ & 100 & 4,746 & 1,659 \\
\hline \multicolumn{4}{|c|}{ Controlling for military regime, monarchy (Banks 2007) } \\
\hline B) & $\begin{array}{l}\text { After year of military defeat in } \\
\text { which leader exited }\end{array}$ & $\begin{array}{l}\text { After year of military defeat with } \\
\text { no leader exit (in the next } 10 \text { years) }\end{array}$ & $\begin{array}{l}\text { All 10-year periods containing no year of military defeat in } \\
\text { which leader exited (but he may have exited in other years) }\end{array}$ \\
\hline & (1) & $(2)$ & (3) \\
\hline & $.93 * *$ & -.06 & $.09 * * *$ \\
\hline & $(.30)$ & $(.05)$ & $(.01)$ \\
\hline$N$ & 14 & 13 & 4,928 \\
\hline \multicolumn{4}{|c|}{ Controlling for military regime, monarchy (Banks 2007) } \\
\hline C) & $\begin{array}{l}\text { After year of global recession in } \\
\text { which leader exited }\end{array}$ & $\begin{array}{l}\text { After year of global recession with } \\
\text { no leader exit (in the next } 10 \text { years) }\end{array}$ & $\begin{array}{c}\text { All 10-year periods containing no year of global recession } \\
\text { in which leader exited (but he may have exited in other } \\
\text { years) }\end{array}$ \\
\hline & (1) & (2) & (3) \\
\hline & $.33^{*}$ & .07 & $.05 * * *$ \\
\hline & $(.16)$ & $(.06)$ & $(.01)$ \\
\hline$N$ & 48 & 70 & 3,384 \\
\hline
\end{tabular}

Source: See Table A18.

Notes: Robust standard errors in parentheses. 
Table A10, column 1, repeats the basic model from Table 2, column 11, for comparison. Subsequent columns control for the average rate of leader turnover in the previous 20,10, and 5 years, and the interactions of this rate with lagged income and leader exit in year $t-1$. The cumulative impact of income conditional on exit in the previous year is hardly changed at all. What activates the link between income and democracy is not leader instability in general but the fact that a leader has actually just exited.

\section{Table A10: Is what matters a predisposition to leader turnover-or actual leader exit?}

\begin{tabular}{|c|c|c|c|c|}
\hline \multirow[t]{2}{*}{ Dependent variable: } & \multicolumn{4}{|c|}{ Polity2 Level of Democracy, Polity ${ }_{t-1}<6,1-y r$ panels } \\
\hline & (1) & $(2)$ & (3) & (4) \\
\hline Polity $2 \mathrm{t}-1$ & $\begin{array}{l}.91 * * * \\
(.01)\end{array}$ & $\begin{array}{l}.91 * * * \\
.01)\end{array}$ & $\begin{array}{l}.91 * * * \\
(.01)\end{array}$ & $\begin{array}{l}.91 * * * \\
(.01)\end{array}$ \\
\hline Leader replaced ${ }_{t-1}$ & $\begin{array}{l}-.08 * * \\
(.04)\end{array}$ & $\begin{array}{l}-.12 * \\
(.07)\end{array}$ & $\begin{array}{l}-.11 \\
(.07)\end{array}$ & $\begin{array}{l}-.11 \\
(.09)\end{array}$ \\
\hline Ln GDP per capita $\mathrm{t}-1$ & $\begin{array}{l}-.001 \\
(.005)\end{array}$ & $\begin{array}{l}-.000 \\
(.005)\end{array}$ & $\begin{array}{l}-.001 \\
(.005)\end{array}$ & $\begin{array}{l}.000 \\
(.005)\end{array}$ \\
\hline $\begin{array}{l}\text { Ln GDP per capita }{ }_{t-1} * \\
\text { leader replaced } t_{t-1}\end{array}$ & $\begin{array}{l}.012 * * \\
(.005)\end{array}$ & $\begin{array}{l}.018 * * \\
(.009)\end{array}$ & $\begin{array}{l}.017^{*} \\
(.010)\end{array}$ & $\begin{array}{l}.018 \\
(.012)\end{array}$ \\
\hline $\begin{array}{l}\text { Rate of leader turnover } \\
\text { previous } 20 \text { years }\end{array}$ & & $\begin{array}{l}.01 \\
(.06)\end{array}$ & & \\
\hline $\begin{array}{l}\text { Rate of leader turnover previous } \\
20 \text { years } * \text { Ln GDP per capita } t-1\end{array}$ & & $\begin{array}{l}-.001 \\
(.009)\end{array}$ & & \\
\hline $\begin{array}{l}\text { Rate of leader turnover previous } \\
20 \text { years } * \text { leader replaced } t-1\end{array}$ & & $\begin{array}{l}.12 \\
(.10)\end{array}$ & & \\
\hline $\begin{array}{l}\text { Rate of leader turnover } 20 \text { years } * \text { Ln } \\
\text { GDP per capita } t_{t-1} * \text { leader replaced }{ }_{t-1}\end{array}$ & & $\begin{array}{l}-.017 \\
(.013)\end{array}$ & & \\
\hline $\begin{array}{l}\text { Rate of leader turnover } \\
\text { previous } 10 \text { years }\end{array}$ & & & $\begin{array}{l}-.01 \\
(.06)\end{array}$ & \\
\hline $\begin{array}{l}\text { Rate of leader turnover previous } \\
10 \text { years * Ln GDP per capita } t-1\end{array}$ & & & $\begin{array}{l}.002 \\
(.008)\end{array}$ & \\
\hline $\begin{array}{l}\text { Rate of leader turnover previous } \\
10 \text { years } * \text { leader replaced } t-1\end{array}$ & & & $\begin{array}{l}.08 \\
(.11)\end{array}$ & \\
\hline $\begin{array}{l}\text { Rate of leader turnover } 10 \text { years } * \text { Ln } \\
\quad \text { GDP per capita } t_{t-1} * \text { leader replaced }{ }_{t-1}\end{array}$ & & & $\begin{array}{l}-.01 \\
(.01)\end{array}$ & \\
\hline $\begin{array}{l}\text { Rate of leader turnover } \\
\text { previous } 5 \text { years }\end{array}$ & & & & $\begin{array}{l}.02 \\
(.05)\end{array}$ \\
\hline $\begin{array}{l}\text { Rate of leader turnover previous } \\
5 \text { years } * \text { Ln GDP per capita } t-1\end{array}$ & & & & $\begin{array}{l}-.003 \\
(.007)\end{array}$ \\
\hline $\begin{array}{l}\text { Rate of leader turnover previous } \\
5 \text { years } * \text { leader replaced } t-1\end{array}$ & & & & $\begin{array}{l}.06 \\
(.11)\end{array}$ \\
\hline $\begin{array}{l}\text { Rate of leader turnover } 5 \text { years } * \text { Ln } \\
\quad \text { GDP per capita } t_{t-1} * \text { leader replaced }{ }_{t-1}\end{array}$ & & & & $\begin{array}{l}-.01 \\
(.01)\end{array}$ \\
\hline $\begin{array}{l}\text { Cumulative effect of income } \\
\text { (at high turnover rate: mean }+1 \mathrm{SD})\end{array}$ & & & & \\
\hline -if leader replaced & $.12(.08)$ & $.10 \quad(.08)$ & $.12 \quad(.08)$ & $.12(.08)$ \\
\hline -if leader not replaced & $-.01(.05)$ & $-.01 \quad(.07)$ & $.00 \quad(.07)$ & $-.02(.06)$ \\
\hline Fisher $\mathrm{p}$ level & {$[.00]$} & {$[.00]$} & {$[.00]$} & {$[.00]$} \\
\hline Observations & 6,425 & 6,372 & 6,372 & 6,372 \\
\hline Countries & 134 & 134 & 134 & 134 \\
\hline R-squared & .8703 & .8706 & .8706 & .8707 \\
\hline
\end{tabular}

Sources: see Table A18 in Appendix. 
Note: All regressions estimated by OLS with country and year fixed effects. Robust standard errors, clustered by country, in parentheses; $* \mathrm{p}<.10,{ }^{* *} \mathrm{p}<.05,{ }^{* * *} \mathrm{p}<.01$. "Fisher $\mathrm{p}$ level": probability level at which one can reject H0: residuals are I(1), from Fisher test of residuals.

The Banks data on opposition mobilization are compiled from newspapers, which raises the concern that reports might be censored in countries with less freedom of the press. In fact, using Freedom House's index of press freedom, I show that the number of reported mobilizations is usually significantly higher in countries with less freedom of the press. It might be that the measures would be higher still if journalists could report more freely, but the variation does not seem to be driven by restrictions on the press. I use the natural log of the number of mobilizations since the distribution for each variable is right-skewed.

Table A11: Popular mobilizations and press freedom, 1994-2008

\begin{tabular}{|c|c|c|c|c|}
\hline $\begin{array}{l}\text { Dependent variable: Ln average } \\
\text { number of events per year, } 1994-2008\end{array}$ & $\begin{array}{c}\text { Antigovernment } \\
\text { demonstrations }\end{array}$ & $\begin{array}{c}\text { General } \\
\text { strikes }\end{array}$ & $\begin{array}{c}\text { Riots } \\
\text { (3) }\end{array}$ & $\begin{array}{c}\text { Attempted } \\
\text { revolutions } \\
(4)\end{array}$ \\
\hline Press freedom, average 1994-2008 & $\begin{array}{l}-.01 \\
(.02)\end{array}$ & $\begin{array}{l}-.0014 * * \\
(.0006)\end{array}$ & $\begin{array}{l}-.003 * * \\
(.001)\end{array}$ & $\begin{array}{l}-.006 * * * \\
(.002)\end{array}$ \\
\hline Growth rate, average 1994-2008 & $\begin{array}{l}-.01 \\
(.01)\end{array}$ & $\begin{array}{c}-.005^{* *} \\
(.002)\end{array}$ & $\begin{array}{l}-.005 \\
(.004)\end{array}$ & $\begin{array}{l}-.000 \\
(.006)\end{array}$ \\
\hline Polity2, average 1994-2008 & $\begin{array}{l}.56 * * * \\
(.12)\end{array}$ & $\begin{array}{c}.17 * * * \\
(.04)\end{array}$ & $\begin{array}{c}.20 * * * \\
(.07)\end{array}$ & $\begin{array}{l}.33 * * * \\
(.12)\end{array}$ \\
\hline Ln GDP per capita, average 1994-2008 & $\begin{array}{l}-.001 \\
(.028)\end{array}$ & $\begin{array}{l}-.001 \\
(.010)\end{array}$ & $\begin{array}{l}-.03 \\
(.02)\end{array}$ & $\begin{array}{c}-.04 * * \\
(.02)\end{array}$ \\
\hline Constant & $\begin{array}{l}.22 \\
(.21)\end{array}$ & $\begin{array}{l}.04 \\
(.08)\end{array}$ & $\begin{array}{l}.33 * \\
(.13)\end{array}$ & $\begin{array}{l}.56 * * * \\
(.15)\end{array}$ \\
\hline $\begin{array}{l}\text { Observations } \\
\text { R-squared }\end{array}$ & $\begin{array}{l}148 \\
.1156\end{array}$ & $\begin{array}{c}148 \\
.0988\end{array}$ & $\begin{array}{l}148 \\
.0736\end{array}$ & $\begin{array}{l}148 \\
.2198\end{array}$ \\
\hline
\end{tabular}

Sources: see Table A18.

Notes: All variables averages for 1994-2008, the years for which Freedom of Press index available. Natural logs of dependent variables used because distributions of all are right skewed. I have reversed the scale on Freedom House's index of press freedom so that higher values indicate more freedom. Robust standard errors in parentheses: $\mathrm{p}<.10, * * \mathrm{p}$ $<.05, * * * \mathrm{p}<.01$. 
In Table A12, the dependent variable is a dummy for leader exit. Here, but only here, leader exit excludes exit due to death from natural causes, suicide, or retirement due to poor health, because these are not likely to be influenced by economic growth, defeat in wars, or the other factors. Rather than restricting attention to nondemocracies, I include all countries and model the difference in the effects in democracies and nondemocracies using interaction terms.

One concern is that regressions of leader replacement on economic growth might pick up the opposite causal process: more leadership change might, by creating uncertainty for investors, inhibit growth. To address this, column 2 estimates a model instrumenting for the growth rate with the average growth rate in other countries, weighted by their trade shares with the given country in the previous year:

$$
g_{a t}=\sum_{b \neq a} \omega_{a b t-1} I_{b t} g_{b t} / \sum_{b \neq a} \omega_{a b t-1} I_{b t}
$$

where $g_{b t}$ is the growth rate of GDP per capita in country $b$ in $t ; I_{b t}$ is an indicator that equals one if the dataset includes data on growth in country $b$ in period $t, 0$ otherwise; and $\omega_{a b t-1}=X_{a b t-1} / Y_{a t-1}$, where $X_{a b t-1}$ is trade between $a$ and $b$ in $t-1$, and $Y_{a t-1}$ is country $a$ 's GDP in $t-1$. The trade data come from Russett, Oneal, and Berbaum (2003); since these data end in 1992, I use the trade weights from 1992 for the years 1993-2008. (This instrument is similar to one AJRY (2008) use for per capita income. I tried to instrument for income using an instrument corresponding to theirs, but in the dataset used here the instruments were too weakly correlated with income to serve adequately.)

To satisfy the exclusion restriction, the instrument should be unrelated to leader turnover by any path other than via growth. It is possible that economic performance in other countries affects the incidence of war, which, if it involves the given country, could influence leader change there. I therefore control here for interstate war. I use the test devised by Stock and Yogo (2005) to check that the instrument is not weak. This test consists of comparing the Cragg-Donald statistic to a set of critical values. We can reject the hypothesis of weak instruments with high confidence.

Some papers have analyzed leader turnover using leader-year data with hazard models (e.g., Chiozza and Goemans 2004). These have a number of attractive features. For instance, besides gauging the impact of independent variables, one can calculate a hazard rate at which leaders are replaced on average, other things equal. As in Bueno de Mesquita and Smith (2010), I fit a Weibull hazard model in column 4 for growth and military defeat, which allows the hazard rate to change over time; how it changes depends on an "ancillary parameter," $p$, which is estimated from the data. I model this parameter as a function of whether the country is a democracy (Polity2 greater than 5).

The main conclusions from this analysis are that: 1) low growth, military defeat, high and increasing opposition mobilization, civil war, and major government crises are all associated with higher odds of leader exit in nondemocracies, and the effect of low growth may well be causal; 2) in nondemocracies, older leaders are more likely to leave office, but longer tenure reduces the odds; 3 ) low growth, major government crisis, and maybe the leader's old age are associated with higher odds of exit in democracies; 4) among nondemocracies, military regimes experience more leader turnover along with personalist regimes; one-party regimes and monarchies experience less. 
Table A12: Explaining leader exit, 1875-2004

\begin{tabular}{|c|c|c|c|c|c|c|c|c|}
\hline \multirow{3}{*}{ One-year panels } & \multicolumn{4}{|c|}{----------Economic growth----------- } & \multicolumn{2}{|c|}{ Military defeat } & \multicolumn{2}{|c|}{ Growth \& milit. defeat } \\
\hline & \multicolumn{2}{|c|}{$\begin{array}{l}\text { Fixed effects } \\
\text { conditional logit, } \\
\text { year dummies }\end{array}$} & \multicolumn{2}{|c|}{$\begin{array}{l}\text { IV, year and } \\
\text { country dummies }\end{array}$} & \multicolumn{2}{|c|}{$\begin{array}{l}\text { Fixed effects } \\
\text { conditional logit, } \\
\text { year dummies }\end{array}$} & \multicolumn{2}{|c|}{$\begin{array}{l}\text { Weibull hazard model, } \\
\text { leader/year data }\end{array}$} \\
\hline & (1) & & $(2)$ & & (3) & & (4) & \\
\hline Growth rate $_{\mathrm{t}}$ & $-.041 * * *$ & $(.006)$ & $-.012 * *$ & $(.006)$ & & & $-.027 * * *$ & $(.005)$ \\
\hline Democracy $_{\mathrm{t}-1} *$ growth rate $_{\mathrm{t}}$ & .016 & $(.011)$ & .000 & $(.007)$ & & & .007 & $(.008)$ \\
\hline Military defeat ${ }_{t}$ & & & & & $1.43 * * *$ & $(.38)$ & $.70 * * *$ & $(.24)$ \\
\hline Democracy $_{\mathrm{t}-1} *$ military defeat ${ }_{\mathrm{t}}$ & & & & & -.78 & $(.98)$ & -.57 & $(.54)$ \\
\hline Democracy $y_{t-1}$ & $3.23 * * *$ & $(.82)$ & $.40 * *$ & $(.18)$ & $3.36 * * *$ & $(.82)$ & $1.65^{*}$ & $(.87)$ \\
\hline Ln GDP per capita $\mathrm{t}-1$ & -.093 & $(.134)$ & -.009 & $(.022)$ & .01 & $(.13)$ & -.017 & $(.060)$ \\
\hline $\begin{array}{l}\text { Proportion other countries } \\
\text { in region with leader exit } t-1\end{array}$ & .60 & $(.40)$ & .032 & $(.073)$ & .65 & $(.41)$ & $1.52 * * *$ & $(.32)$ \\
\hline Leader's age $_{\mathrm{t}-1}$ & $.032 * * *$ & $(.004)$ & $.0044 * * *$ & (.0009) & $.033 * * *$ & $(.004)$ & $.021 * * *$ & $(.004)$ \\
\hline Previous times in office ${ }_{t-1}$ & -.051 & $(.079)$ & -.004 & $(.013)$ & -.057 & $(.079)$ & $.10^{* *}$ & $(.05)$ \\
\hline Leader's years in office this time $t_{t-1}$ & $-.053 * * *$ & $(.007)$ & $-.005 * * *$ & $(.001)$ & $-.055 * * *$ & $(.007)$ & $-.029 * * *$ & $(.007)$ \\
\hline $\begin{array}{l}\text { Dem }_{\mathrm{t}-1} * \ln \text { GDP per capita } \mathrm{t}-1 \\
\text { Dem }_{\mathrm{t}-1} * \text { proportion other countries }\end{array}$ & $-.24 * *$ & $(.10)$ & -.031 & $(.019)$ & $-.25 * *$ & $(.10)$ & -.039 & $(.10)$ \\
\hline in region with leader exit $t_{t-1}$ & -.48 & $(.52)$ & .01 & $(.11)$ & -.50 & $(.52)$ & $-.81 *$ & $(.42)$ \\
\hline $\operatorname{Dem}_{\mathrm{t}-1} *$ leader's age $\mathrm{t}_{\mathrm{t}-1}$ & $-.019 * * *$ & $(.007)$ & -.002 & $(.002)$ & $-.020 * * *$ & $(.007)$ & $-.021 * * *$ & $(.006)$ \\
\hline Dem $_{t-1} *$ previous times in office $t-1$ & .09 & $(.11)$ & .015 & $(.026)$ & .09 & $(.11)$ & .10 & $(.08)$ \\
\hline Dem $_{\mathrm{t}-1} *$ leader's years in office $\mathrm{t}-1$ & $.042 * * *$ & $(.013)$ & .004 & $(.005)$ & $.044 * * *$ & $(.013)$ & -.016 & $(.027)$ \\
\hline Interstate war & & & -.04 & $(.03)$ & & & & \\
\hline Constant & & & & & & & $-2.23 * * *$ & $(.46)$ \\
\hline \multicolumn{9}{|l|}{ Ancillary parameter $(\ln (\mathrm{p}))$} \\
\hline Democracy Dummy & & & & & & & $.29 * * *$ & $(.08)$ \\
\hline Constant & & & & & & & $-.40 * * *$ & $(.04)$ \\
\hline \multicolumn{9}{|l|}{ Effect when nondemocracy ${ }_{t-1}$} \\
\hline Growth rate $_{\mathrm{t}}$ & $-.041 * * *$ & $(.006)$ & $-.012 * *$ & $(.006)$ & & & $-.027 * * *$ & $(.005)$ \\
\hline Military defeat ${ }_{t}$ & & & & & $1.43 * * *$ & $(.38)$ & $.70 * * *$ & $(.24)$ \\
\hline Ln GDP per capita $t-1$ & -.093 & $(.134)$ & -.009 & $(.022)$ & .01 & $(.13)$ & -.017 & $(.060)$ \\
\hline Leader's age $\mathrm{t}_{\mathrm{t}-1}$ & $.032 * * *$ & $(.004)$ & $.0044 * * *$ & (.0009) & $.033 * * *$ & $(.004)$ & $.021 * * *$ & $(.004)$ \\
\hline Leader's years in office $t_{t-1}$ & $-.053 * * *$ & $(.007)$ & -.004 & $(.013)$ & $-.055 * * *$ & $(.007)$ & $-.029 * * *$ & $(.007)$ \\
\hline \multicolumn{9}{|l|}{ Effect when democracy ${ }_{t-1}$} \\
\hline Growth rate $_{\mathrm{t}}$ & $-.025 * *$ & $(.010)$ & -.012 & $(.008)$ & & & $-.020 * * *$ & $(.007)$ \\
\hline Military defeat ${ }_{t}$ & & & & & .64 & $(.91)$ & .13 & $(.49)$ \\
\hline Ln GDP per capita $t-1$ & $-.34 * * *$ & $(.12)$ & $-.040 *$ & $(.024)$ & $-.24 * *$ & $(.12)$ & -.06 & $(.08)$ \\
\hline Leader's age $\mathrm{t}_{\mathrm{t}-1}$ & $.013 * *$ & $(.005)$ & .002 & $(.002)$ & $.013 * *$ & $(.005)$ & .000 & $(.005)$ \\
\hline Leader's years in office $t_{t-1}$ & -.011 & $(.011)$ & -.002 & $(.005)$ & -.011 & $(.011)$ & $-.045^{*}$ & $(.027)$ \\
\hline Cragg-Donald & & & 96.56 & & & & & \\
\hline Stock Yogo (size) & & & $10 \%$ & & & & & \\
\hline Observations & 9,268 & & 7,745 & & 9,255 & & 11,847 & \\
\hline Countries & 142 & & 145 & & 142 & & 155 & \\
\hline
\end{tabular}

Sources: see Table A18.

Note: Standard errors in parentheses (robust and clustered by country in column 2 ); ${ }^{*} \mathrm{p}<.10,{ }^{* *} \mathrm{p}<.05, * * * \mathrm{p}<.01$.

"Democracy $\mathrm{t}_{\mathrm{t}-1}$ " here indicates that Polity $2_{\mathrm{t}-1} \geq 6$. 
Table A12: Explaining leader exit (cont.)

\begin{tabular}{|c|c|c|c|c|c|c|c|c|}
\hline \multicolumn{9}{|c|}{ Dependent variable is dummy for leader exit (except due to natural death, suicide, or retirement due to poor health) } \\
\hline & \multicolumn{8}{|c|}{ All columns: fixed effects conditional logit, year dummies } \\
\hline & \multicolumn{2}{|l|}{$(5)$} & \multicolumn{2}{|c|}{ (6) } & \multicolumn{2}{|c|}{ (7) Banks data } & \multicolumn{2}{|c|}{ (8) Geddes data } \\
\hline Ln AGDs t-2 & $.48 * * *$ & $(.11)$ & & & & & & \\
\hline$\Delta \mathrm{AGDs}_{\mathrm{t}-1}$ & $.10 * * *$ & $(.03)$ & & & & & & \\
\hline Democracy $_{\mathrm{t}-1} * \ln \mathrm{AGDs}_{\mathrm{t}-2}$ & $-.35 * *$ & $(.15)$ & & & & & & \\
\hline Democracy $_{\mathrm{t}-1} * \Delta$ AGDs $_{\mathrm{t}-1}$ & $-.10 * * *$ & $(.04)$ & & & & & & \\
\hline Assassinations $\mathrm{t}-1$ & & & -.003 & $(.045)$ & & & & \\
\hline Guerilla warfare $_{t-1}$ & & & -.021 & $(.046)$ & & & & \\
\hline Major government crisis $t-1$ & & & $.52 * * *$ & $(.07)$ & & & & \\
\hline Civil war ${ }_{t-1}$ & & & $.49 * *$ & $(.21)$ & & & & \\
\hline Democracy $_{\mathrm{t}-1} *$ assassinations $_{\mathrm{t}-1}$ & & & .006 & $(.063)$ & & & & \\
\hline Democracy $_{\mathrm{t}-1} *$ guerilla warfare $_{\mathrm{t}-1}$ & & & -.12 & $(.11)$ & & & & \\
\hline Democracy $_{\mathrm{t}-1} *_{\text {crisis }} \mathrm{t}-1$ & & & .05 & $(.10)$ & & & & \\
\hline Democracy $_{\mathrm{t}-1} *$ civil war $_{\mathrm{t}-1}$ & & & -.05 & $(.34)$ & & & & \\
\hline Military regime $_{t-1}$ & & & & & $.51 * * *$ & $(.17)$ & $.67 * * *$ & $(.18)$ \\
\hline Monarchy $\mathrm{t}-1$ & & & & & -.20 & $(.16)$ & -.06 & $(.36)$ \\
\hline Personalist regime $_{\mathrm{t}-1}$ & & & & & & & $.41 * *$ & $(.19)$ \\
\hline Miscellaneous regime $_{t-1}$ & & & & & & & $.90 * * *$ & $(.19)$ \\
\hline Democracy $_{\mathrm{t}-1}$ & $4.11 * * *$ & $(1.00)$ & $4.43 * * *$ & $(.99)$ & $3.30 * * *$ & $(.85)$ & $3.29 * * *$ & $(1.11)$ \\
\hline Ln GDP per capita $t-1$ & .16 & $(.17)$ & .25 & $(.16)$ & .03 & $(.14)$ & $.42 * *$ & $(.18)$ \\
\hline $\begin{array}{l}\text { Proportion other countries } \\
\text { in region with leader exit } t-1\end{array}$ & .56 & $(.48)$ & .59 & $(.49)$ & $.74 *$ & $(.43)$ & $1.09 *$ & $(.56)$ \\
\hline Leader's age $_{\mathrm{t}-1}$ & $.040 * * *$ & $(.006)$ & $.039 * * *$ & $(.005)$ & $.035 * * *$ & $(.005)$ & $.038 * * *$ & $(.006)$ \\
\hline Previous times in office $t-1$ & -.044 & $(.110)$ & -.068 & $(.111)$ & -.021 & $(.082)$ & -.19 & $(.12)$ \\
\hline Leader's years in office ${ }_{t-1}$ & $-.049 * * *$ & $(.009)$ & $-.042 * * *$ & $(.009)$ & $-.056 * * *$ & $(.007)$ & $-.029 * * *$ & $(.010)$ \\
\hline $\operatorname{Dem}_{\mathrm{t}-1} * \ln$ GDP per capita $\mathrm{t}-1$ & $-.21 *$ & $(.12)$ & $-.31 * *$ & $(.12)$ & $-.23 * *$ & $(.11)$ & -.12 & $(.14)$ \\
\hline $\begin{array}{l}\text { Dem }_{\mathrm{t}-1} * \text { proportion other } \\
\text { in region with leader exit } \mathrm{t}-1\end{array}$ & -.13 & $(.62)$ & -.45 & $(.62)$ & -.68 & $(.55)$ & $-1.36 *$ & $(.76)$ \\
\hline $\operatorname{Dem}_{\mathrm{t}-1} *$ leader's age $_{\mathrm{t}-1}$ & $-.039 * * *$ & $(.008)$ & $-.033 * * *$ & $(.008)$ & $-.021 * * *$ & $(.007)$ & $-.029 * * *$ & $(.009)$ \\
\hline Dem $_{\mathrm{t}-1} *$ previous times in office $\mathrm{t}$ - & .09 & $(.14)$ & .09 & $(.14)$ & .06 & $(.11)$ & .13 & $(.16)$ \\
\hline Dem $_{\mathrm{t}-1} *$ leader's years in office $\mathrm{t}_{\mathrm{t} 1}$ & $.122 * * *$ & $(.02)$ & $.132 * * *$ & $(.019)$ & $.050 * * *$ & $(.013)$ & $.137 * * *$ & $(.022)$ \\
\hline \multicolumn{9}{|l|}{ Effect when nondemocracy ${ }_{t-1}$} \\
\hline Ln AGDs $t-2$ & $.48 * * *$ & $(.11)$ & & & & & & \\
\hline$\Delta \mathrm{AGDs}_{\mathrm{t}-1}$ & $.10 * * *$ & $(.03)$ & & & & & & \\
\hline Assassinations $_{\mathrm{t}-1}$ & & & -.003 & $(.045)$ & & & & \\
\hline Guerilla warfare $_{\mathrm{t}-1}$ & & & -.021 & $(.046)$ & & & & \\
\hline Major government crisis $\mathrm{t}_{\mathrm{t}-1}$ & & & $.52 * * *$ & $(.07)$ & & & & \\
\hline Civil war $\mathrm{t}_{\mathrm{t}-1}$ & & & $.49 * *$ & $(.21)$ & & & & \\
\hline Ln GDP per capita $t_{t-1}$ & .16 & $(.17)$ & .25 & $(.16)$ & .03 & $(.14)$ & $.42 * *$ & $(.18)$ \\
\hline Leader's age $\mathrm{t}_{\mathrm{t}-1}$ & $.040 * * *$ & $(.006)$ & $.039 * * *$ & $(.005)$ & $.035 * * *$ & $(.005)$ & $.038 * * *$ & $(.006)$ \\
\hline Leader's years in office $t_{t-1}$ & $-.049 * * *$ & $(.009)$ & $-.042 * * *$ & $(.009)$ & $-.056 * * *$ & $(.007)$ & $-.029 * * *$ & $(.010)$ \\
\hline \multicolumn{9}{|l|}{ Effect when democracy $y_{t-1}$} \\
\hline Ln AGDs ${ }_{t-2}$ & .13 & $(.11)$ & & & & & & \\
\hline$\Delta \mathrm{AGDs}_{\mathrm{t}-1}$ & .005 & $(.025)$ & & & & & & \\
\hline Assassinations $_{\mathrm{t}-1}$ & & & .004 & $(.044)$ & & & & \\
\hline Guerilla warfare $_{\mathrm{t}-1}$ & & & -.14 & $(.10)$ & & & & \\
\hline Major government crisis $\mathrm{t}_{\mathrm{t}-1}$ & & & $.57 * * *$ & $(.07)$ & & & & \\
\hline Civil war $\mathrm{t}_{\mathrm{t}-1}$ & & & .44 & $(.28)$ & & & & \\
\hline Ln GDP per capita $\mathrm{t}-1$ & -.04 & $(.14)$ & -.05 & $(.14)$ & -.19 & $(.12)$ & $.30 *$ & $(.17)$ \\
\hline Leader's age $t-1$ & .001 & $(.006)$ & .007 & $(.006)$ & $.013 * *$ & $(.006)$ & .009 & $(.007)$ \\
\hline Leader's years in office $t-1$ & $.073 * * *$ & $(.017)$ & $.090 * * *$ & $(.017)$ & -.006 & $(.011)$ & $.11 * * *$ & $(.02)$ \\
\hline Excluded category & & & & & Other non & -dem & One-party & \\
\hline Observations & 6,942 & & 7,123 & & 8,578 & & 6,163 & \\
\hline Countries & 134 & & 135 & & 137 & & 134 & \\
\hline
\end{tabular}

Sources: see Table A18.

Note: Standard errors in parentheses; $* \mathrm{p}<.10, * * \mathrm{p}<.05, * * * \mathrm{p}<.01$. "Democracy $\mathrm{t}-1$ " here indicates that Polity $2 \mathrm{t}-1 \geq 6$. 


\section{Table A13: Possible confounding factors}

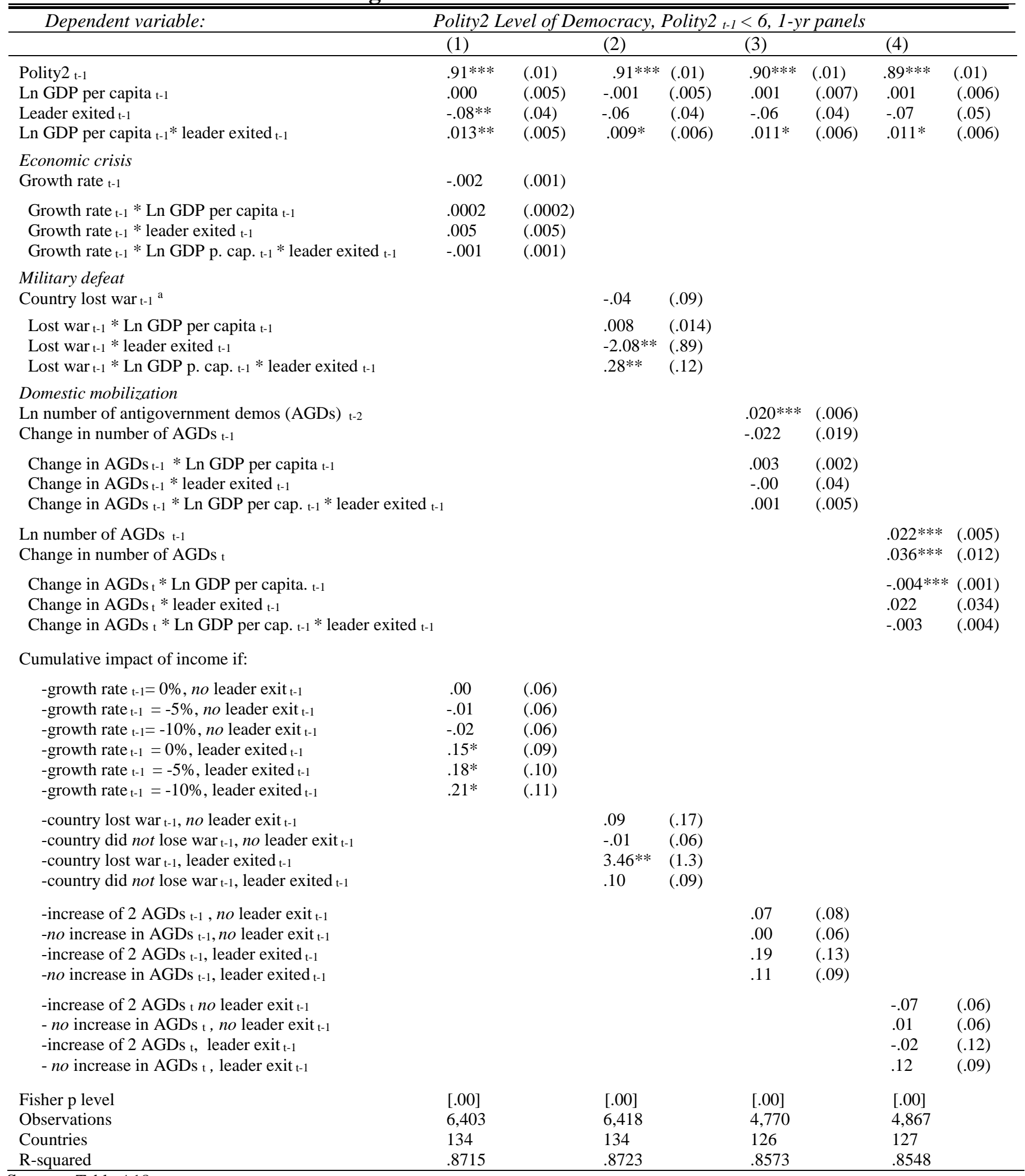

Sources: Table A18.

Note: OLS with country and year fixed effects. Robust standard errors, clustered by country, in parentheses; $* \mathrm{p}<.10, * * \mathrm{p}<.05, * * * \mathrm{p}<$ .01. "Fisher p level": probability level at which one can reject H0: residuals are I(1), from Fisher test of residuals. ${ }^{\text {a }}$ excluding military defeats followed (within 10 years) by foreign occupation or imposition of leader. If one excludes wars with fewer than 500 battle deaths, the cumulative effect of income if the country lost a war but no leader exited increases to .18 (still not significant), but little else changes. 
Table A13: Possible confounding factors (cont.)

\begin{tabular}{|c|c|c|c|c|c|c|c|c|}
\hline \multirow[t]{3}{*}{ Dependent variable: } & \multicolumn{7}{|c|}{ Polity2 Level of Democracy, Polity $2_{t-1}<6,1-y r$ panels } & \\
\hline & \multicolumn{2}{|c|}{$(5)$} & \multicolumn{2}{|c|}{$(6)$} & \multicolumn{2}{|c|}{$(7)$} & \multicolumn{2}{|c|}{$(8)$} \\
\hline & $.89 * * *$ & $(.01)$ & $.90 * * *$ & $(.01)$ & $.91 * * *$ & $(.01)$ & $.89 * * *$ & $(.01)$ \\
\hline Leader exited $\mathrm{t}_{\mathrm{t}-1}$ & $-.10^{*}$ & $(.05)$ & $-.09 *$ & $(.05)$ & $-.08 * *$ & $(.04)$ & -.05 & $(.05)$ \\
\hline Ln GDP per capita $\mathrm{t}_{\mathrm{t}-1} *$ leader exit $\mathrm{t}-1$ & $.016 * *$ & $(.007)$ & $.014 * *$ & $(.007)$ & $.012 * *$ & $(.005)$ & .009 & $(.006)$ \\
\hline $\operatorname{ASS}_{\mathrm{t}-1} *$ leader exited $\mathrm{t}-1$ & $.081 *$ & $(.048)$ & & & & & & \\
\hline $\operatorname{ASS}_{\mathrm{t}-1} *$ Ln GDP p. cap. $\mathrm{t}-1^{*}$ leader exit $\mathrm{t}-1$ & $-.010 *$ & $(.006)$ & & & & & & \\
\hline Guerrilla warfare $\mathrm{t}-1$ & & & -.006 & $(.016)$ & & & & \\
\hline Guerrilla warfare $\mathrm{t}-1 *$ Ln GDP per capita $\mathrm{t}-1$ & & & .001 & $(.002)$ & & & & \\
\hline Civil war $_{\mathrm{t}-1} *$ Ln GDP per capita $\mathrm{t}-1$ & & & & & .011 & $(.008)$ & & \\
\hline Civil war $_{\mathrm{t}-1} *$ leader exited $\mathrm{t}-1$ & & & & & .065 & $(.118)$ & & \\
\hline Civil war ${ }_{t-1} *$ Ln GDP per cap. $t-1 *$ leader exit $t-1$ & & & & & -.010 & $(.016)$ & & \\
\hline Major government crisis $\mathrm{t}-1$ & & & & & & & -.005 & $(.037)$ \\
\hline Crisis $_{\mathrm{t}-1} *$ Ln GDP per capita $\mathrm{t}-1$ & & & & & & & .001 & $(.005)$ \\
\hline Crisis $t-1 *$ leader exited $t-1$ & & & & & & & -.039 & $(.057)$ \\
\hline Crisis. $\mathrm{t}-1^{*}$ Ln GDP p. cap. $\mathrm{t}-1 *$ leader exit $\mathrm{t}-1$ & & & & & & & .006 & $(.008)$ \\
\hline \multicolumn{9}{|l|}{ Cumulative impact of income if: } \\
\hline -assassination $\mathrm{t}-1_{1}$, no leader exit $\mathrm{t}_{\mathrm{t}-1}$ & .00 & $(.07)$ & & & & & & \\
\hline$-n o$ assassination $\mathrm{t}_{\mathrm{t}-1}$, no leader exit $\mathrm{t}-1$ & .01 & $(.06)$ & & & & & & \\
\hline$-n o$ civil war $\mathrm{t}-1$, no leader exit $\mathrm{t}-1$ & & & & & -.00 & $(.05)$ & & \\
\hline -civil war ${ }_{t-1}$, leader exit $t_{-1}$ & & & & & .14 & $(.18)$ & & \\
\hline$-n o$ civil war ${ }_{t-1}$, leader exit $t_{t-1}$ & & & & & .13 & $(.08)$ & & \\
\hline -major gov. crisis $\mathrm{t}-1_{1}$ no leader exit $\mathrm{t}-1$ & & & & & & & .03 & $(.08)$ \\
\hline -no major gov. crisis $\mathrm{t}_{\mathrm{t}-1}$, no leader exit $\mathrm{t}_{\mathrm{t}-1}$ & & & & & & & .02 & $(.06)$ \\
\hline -major gov. crisis $t-1$, leader exit $t_{t-1}$ & & & & & & & .16 & $(.10)$ \\
\hline$-n o$ major gov. crisis $\mathrm{t}_{\mathrm{t}-1}$, leader exit $\mathrm{t}-1$ & & & & & & & .10 & $(.08)$ \\
\hline Fisher $\mathrm{p}$ level & {$[.00]$} & & {$[.00]$} & & {$[.00]$} & & {$[.00]$} & \\
\hline Observations & 4,906 & & 4,906 & & 6,425 & & 4,906 & \\
\hline Countries & 127 & & 127 & & 134 & & 127 & \\
\hline R-squared & .8535 & & .8534 & & .8706 & & .8536 & \\
\hline
\end{tabular}

Sources: Table A18.

Note: OLS with country and year fixed effects. Robust standard errors, clustered by country, in parentheses; $* \mathrm{p}<.10, * * \mathrm{p}<.05, * * * \mathrm{p}<$ .01. "Fisher p level": probability level at which one can reject H0: residuals are I(1), from Fisher test of residuals. 
Table A14.A: Different authoritarian subtypes (Banks data)

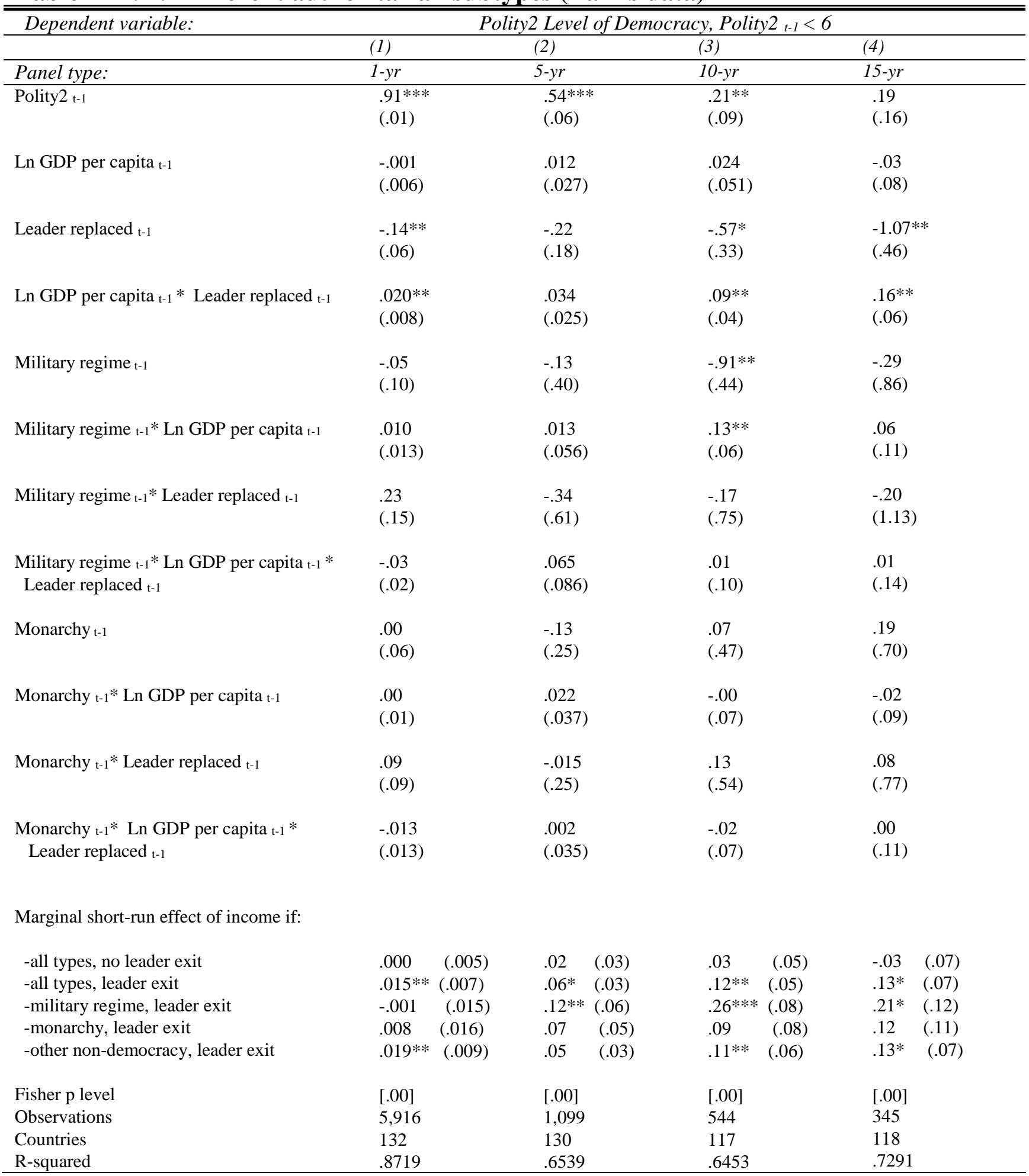

Sources: see Table A18.

Note: All estimations by OLS with country and year fixed effects. Robust standard errors, clustered by country, in parentheses; $* \mathrm{p}<.10, * * \mathrm{p}<.05, * * * \mathrm{p}<.01$. "Fisher $\mathrm{p}$ level" is probability level at which one can reject H0: residuals are I(1), from Fisher test of residuals. Margins not estimable for 20-year panels. 
Table A14.B: Different authoritarian subtypes (Geddes et al. data)

\begin{tabular}{|c|c|c|c|}
\hline Dependent variable: & \multicolumn{3}{|c|}{ Polity2 Level of Democracy, Polity $2_{t-1}<6$} \\
\hline Panel type: & $1-y r$ & $5-y r$ & $10-y r$ \\
\hline & $(1)$ & (2) & (3) \\
\hline Polity $2 \mathrm{t}-1$ & $.90 * * *(.02)$ & $.48 * * *(.08)$ & $.02(.14)$ \\
\hline Ln GDP per capita $\mathrm{t}-1$ & $.003(.012)$ & $.03(.08)$ & $-.22(.13)$ \\
\hline Leader replaced $t-1$ & $-.09(.15)$ & $-.34(.71)$ & $-2.28 * *(.98)$ \\
\hline Ln GDP per capita $\mathrm{t}-1 *$ leader replaced $\mathrm{t}-1$ & $.013(.020)$ & $.05(.10)$ & $.31 * *(.13)$ \\
\hline Monarchy $\mathrm{t}-1$ & $.03(.08)$ & $.39(.49)$ & $-.64(.85)$ \\
\hline Monarchy $\mathrm{t}-1 * \ln$ GDP per capita $\mathrm{t}-1$ & $-.01(.01)$ & $-.06(.07)$ & $.09(.12)$ \\
\hline Monarchy $\mathrm{t}-1 *$ leader replaced $\mathrm{t}-1$ & $.12(.16)$ & $.21(.73)$ & $1.89 *(1.11)$ \\
\hline Mon. $\mathrm{t}-1^{*} \ln$ GDP per capita $\mathrm{t}_{\mathrm{t}-1} *$ leader replaced $\mathrm{t}-1$ & $-.01(.02)$ & $-.03(.10)$ & $-.25 *(.15)$ \\
\hline Personalist $t_{t-1}$ & $.01(.09)$ & $-.13(.54)$ & $-1.57(1.04)$ \\
\hline Personalist $\mathrm{t}_{\mathrm{t}-1} * \ln$ GDP per capita $\mathrm{t}-1$ & $-.01(.01)$ & $-.00(.08)$ & $.20(.14)$ \\
\hline Personalist $t_{\mathrm{t}-1} *$ leader replaced $\mathrm{t}-1$ & $-.09(.18)$ & $-.37(.82)$ & $1.01(1.20)$ \\
\hline Pers. ${ }_{\mathrm{t}-1} * \ln$ GDP per capita $\mathrm{t}-1 *$ leader replaced $\mathrm{t}-1$ & $.02(.03)$ & $.07(.11)$ & $-.10(.16)$ \\
\hline One Party $\mathrm{t}-1$ & $.02(.08)$ & $.22(.53)$ & $-1.69 *(1.00)$ \\
\hline One Party $\mathrm{t}-1 * \ln$ GDP per capita $\mathrm{t}-1$ & $-.01(.01)$ & $-.04(.08)$ & $.22(.14)$ \\
\hline One Party $\mathrm{t}-1 *$ leader replaced $\mathrm{t}-1$ & $-.06(.19)$ & $-.29(.77)$ & $1.37(1.09)$ \\
\hline One P. $t_{-1} * \ln$ GDP per capita $t-1 *$ leader replaced $t-1$ & $.01(.03)$ & $.04(.11)$ & $-.19(.15)$ \\
\hline Miscellaneous $\mathrm{t}-1$ & $.02(.11)$ & $-.52(.65)$ & $-2.51 * *(1.26)$ \\
\hline Miscellaneous $\mathrm{t}-1 * \ln$ GDP per capita $\mathrm{t}-1$ & $-.01(.01)$ & $.07(.09)$ & $.30 *(.17)$ \\
\hline Miscellaneous $\mathrm{t}-1^{*}$ leader replaced $\mathrm{t}-1$ & $-.00(.26)$ & $.94(.98)$ & $2.69(1.67)$ \\
\hline Misc. ${ }_{\mathrm{t}-1} * \ln$ GDP per capita $\mathrm{t}-1 *$ leader replaced $\mathrm{t}-1$ & $.00(.04)$ & $-.13(.13)$ & $-.32(.22)$ \\
\hline Cumulative effect of income if: & & & \\
\hline -all types, leader exit & $(.011)$ & $(.044)$ & $.104 \quad(.077)$ \\
\hline -all types, no leader exit & $-.003 \quad(.007)$ & $(.040)$ & $-.039 \quad(.078)$ \\
\hline -monarchy, leader exit & $-.004 \quad(.009)$ & $(.042)$ & $-.071(.092)$ \\
\hline -personalist, leader exit & $.028 \quad(.017)$ & $.144 * *(.072)$ & $.188 \quad(.120)$ \\
\hline -one party, leader exit & $(.017)$ & $(.056)$ & $.126 \quad(.094)$ \\
\hline -military regime, leader exit & $(.021)$ & $(.075)$ & $.090 \quad(.097)$ \\
\hline -misc., leader exit & $(.019)$ & $(.074)$ & $.071 \quad(.105)$ \\
\hline Fisher $\mathrm{p}$ level & {$[.00]$} & {$[.00]$} & {$[.00]$} \\
\hline Observations & 4,263 & 749 & 358 \\
\hline Countries & 119 & 117 & 104 \\
\hline R-squared & .8500 & .6446 & .7161 \\
\hline
\end{tabular}

Sources: see Table A18.

Note: All estimations by OLS with country and year fixed effects. Robust standard errors, clustered by country, in parentheses; $* \mathrm{p}<.10, * * \mathrm{p}<.05, * * * \mathrm{p}<.01$. "Fisher $\mathrm{p}$ level" is probability level at which one can reject H0: residuals are I( 1$)$, from Fisher test of residuals. Too few remaining observations to calculate for 15 and 20 -year panels without serious stationarity problems. Military is excluded category. 
Table A15 analyzes whether the mode of exit affects the impact of income on democratization.

Archigos distinguishes several ways leaders leave office. Besides dying from natural causes, committing suicide, retiring due to poor health, or being deposed by a foreign force, they may be replaced in a "regular" or an "irregular" manner. "Regular" replacements occur "according to the prevailing rules, provisions, conventions, and norms of the country" (Goemans et al. 2009, p.272). Although such turnovers are the rule in democracies, they also occur in authoritarian regimes, as, for instance, when a new leader takes over in a faked election or a monarch abdicates in favor of his son. "Irregular" replacements occur amid abnormal events such as military coups or popular revolts.

I show regressions in which each type of leader exit is interacted with income. In models 1-5, the dependent variable is the level of Polity2. Models 6-10 use the Boix-Miller-Rosato binary measure of democracy, and include only non-democracies, so the regressions measure the probability of transition to democracy. For why it is necessary to estimate models 6-10 with a linear probability model, see footnote on p.2.

In the multiyear panels, when more than one change of leader occurs within the period, I focus on the final mode of leader exit. (If a regular turnover is followed by a revolution that sweeps away the old leader, one would expect the revolution to affect the type of regime at the end of the period more than the earlier turnover.) As before, I also adjust so that a leader exit is coded zero if it comes in a period when there was net increase in Polity 2 but none of the net increase in Polity 2 came after the leader change. This is to avoid attributing liberalization to leader change that did not precede the liberalization.

Note that these panel regressions are a far less efficient way of estimating the impact of death by natural causes than the comparison of means in Table 3. There, I examine all 10-year periods after a leader's natural death. Here, I examine each 10 year panel-period that contains a leader's natural death - whether the death occurred in the first, the last, or some other year of the panel. If the effect is actually felt 5 years after the leader's death, the regressions will not capture this for the cases where the leader died less than 5 years before the end of the panel. 
Table A15: Democratization given different modes of leader exit

\begin{tabular}{|c|c|c|c|c|c|c|c|c|c|c|}
\hline \multirow[t]{2}{*}{ Dependent variable } & \multicolumn{5}{|c|}{$\begin{array}{c}\text { Levels: Polity2, } \\
\text { Polity } 2_{t-1}<6,1875-2004\end{array}$} & \multicolumn{5}{|c|}{$\begin{array}{l}\text { Transitions:BMR binary measure, } \\
\text { only non-democracies, } 1875-2000\end{array}$} \\
\hline & (1) & (2) & (3) & (4) & (5) & (6) & (7) & (8) & (9) & (10) \\
\hline Panel type & $1-y r$ & $5-y r$ & $10-y r$ & $15-y r$ & $20-y r$ & $1-y r$ & $5-y r$ & $10-y r$ & $15-y r$ & $20-y r$ \\
\hline Polity $2 \mathrm{t}-1$ & $\begin{array}{l}.91 * * * \\
(.01)\end{array}$ & $\begin{array}{l}.55^{* * *} \\
(.07)\end{array}$ & $\begin{array}{l}.21 * * \\
(.10)\end{array}$ & $\begin{array}{l}.23 \\
(.14)\end{array}$ & $\begin{array}{l}.16 \\
(.10)\end{array}$ & & & & & \\
\hline Ln GDP per capita $t_{t-1}$ & $\begin{array}{l}-.001 \\
(.005)\end{array}$ & $\begin{array}{l}.04 \\
(.03)\end{array}$ & $\begin{array}{l}.09 * \\
(.05)\end{array}$ & $\begin{array}{l}.14 * * \\
(.07)\end{array}$ & $\begin{array}{l}.19 \\
(.12)\end{array}$ & $\begin{array}{l}-.00 \\
(.01)\end{array}$ & $\begin{array}{l}.03 \\
(.04)\end{array}$ & $\begin{array}{l}.15^{* *} \\
(.06)\end{array}$ & $\begin{array}{l}.18^{*} \\
(.11)\end{array}$ & $\begin{array}{l}.19 \\
(.15)\end{array}$ \\
\hline Leader exit regular ${ }_{t-1}$ & $\begin{array}{l}-.19 * * \\
(.08)\end{array}$ & $\begin{array}{l}-.28 \\
(.29)\end{array}$ & $\begin{array}{l}-.74 * \\
(.40)\end{array}$ & $\begin{array}{l}-.61 \\
(.53)\end{array}$ & $\begin{array}{l}-.81 \\
(.57)\end{array}$ & $\begin{array}{c}-.37 * * \\
(.17)\end{array}$ & $\begin{array}{c}-.93 * * \\
(.44)\end{array}$ & $\begin{array}{l}-1.33^{* *} \\
(.63)\end{array}$ & $\begin{array}{l}-1.03 \\
(.90)\end{array}$ & $\begin{array}{l}-1.41 \\
(1.08)\end{array}$ \\
\hline Leader exit irregular $r_{t-1}$ & $\begin{array}{l}-.05 \\
(.07)\end{array}$ & $\begin{array}{l}.11 \\
(.20)\end{array}$ & $\begin{array}{l}.06 \\
(.35)\end{array}$ & $\begin{array}{l}.65 \\
(.51)\end{array}$ & $\begin{array}{l}.40 \\
(.70)\end{array}$ & $\begin{array}{l}-.27 * \\
(.15)\end{array}$ & $\begin{array}{l}-.19 \\
(.28)\end{array}$ & $\begin{array}{l}.24 \\
(.45)\end{array}$ & $\begin{array}{l}.55 \\
(.69)\end{array}$ & $\begin{array}{l}.40 \\
(.82)\end{array}$ \\
\hline $\begin{array}{l}\text { Leader died in office of } \\
\text { natural causes } t-1\end{array}$ & $\begin{array}{l}-.03 \\
(.07)\end{array}$ & $\begin{array}{l}-.01 \\
(.13)\end{array}$ & $\begin{array}{l}-.02 \\
(.30)\end{array}$ & $\begin{array}{l}.58 \\
(.48)\end{array}$ & $\begin{array}{l}-.02 \\
(.90)\end{array}$ & $\begin{array}{l}-.09 \\
(.13)\end{array}$ & $\begin{array}{l}.10 \\
(.21)\end{array}$ & $\begin{array}{l}.27 \\
(.34)\end{array}$ & $\begin{array}{l}.39 \\
(.77)\end{array}$ & $\begin{array}{l}-.71 \\
(1.13)\end{array}$ \\
\hline Leader deposed ${ }_{t-1}$ & $\begin{array}{l}-.10 \\
(.08)\end{array}$ & $\begin{array}{l}-.02 \\
(.56)\end{array}$ & $\begin{array}{l}1.12 * \\
(.59)\end{array}$ & $\begin{array}{l}.44 \\
(1.15)\end{array}$ & $\begin{array}{l}.53 \\
(.79)\end{array}$ & $\begin{array}{l}-.44 \\
(.43)\end{array}$ & $\begin{array}{l}-.62 \\
(.75)\end{array}$ & $\begin{array}{l}.84 \\
(.63)\end{array}$ & $\begin{array}{l}-.57 \\
(1.07)\end{array}$ & $\begin{array}{l}-2.09 * \\
(1.18)\end{array}$ \\
\hline $\begin{array}{l}\text { Leader retired due to } \\
\text { poor health } \mathrm{t}-1\end{array}$ & $\begin{array}{l}.31 \\
(.43)\end{array}$ & $\begin{array}{l}-.03 \\
(.41)\end{array}$ & $\begin{array}{l}.14 \\
(.58)\end{array}$ & $\begin{array}{l}1.60 * * \\
(.68)\end{array}$ & $\begin{array}{l}-.92 \\
(1.67)\end{array}$ & $\begin{array}{l}-.23 * * \\
(.11)\end{array}$ & $\begin{array}{l}-.37 \\
(.30)\end{array}$ & $\begin{array}{l}.80 \\
(1.77)\end{array}$ & $\begin{array}{l}1.06 \\
(1.51)\end{array}$ & $\begin{array}{l}2.08 \\
(1.38)\end{array}$ \\
\hline $\begin{array}{l}\text { Regular leader exit } \mathrm{t}_{\mathrm{t}-1} * \\
\text { ln GDP per capita } \mathrm{t}_{-1}\end{array}$ & $\begin{array}{l}.03 * * \\
(.01)\end{array}$ & $\begin{array}{l}.04 \\
(.04)\end{array}$ & $\begin{array}{l}.10 * \\
(.05)\end{array}$ & $\begin{array}{l}.08 \\
(.07)\end{array}$ & $\begin{array}{l}.10 \\
(.07)\end{array}$ & $\begin{array}{l}.05 * * \\
(.02)\end{array}$ & $\begin{array}{l}.13 * * \\
(.06)\end{array}$ & $\begin{array}{l}.17^{*} \\
(.09)\end{array}$ & $\begin{array}{l}.13 \\
(.12)\end{array}$ & $\begin{array}{l}.16 \\
(.14)\end{array}$ \\
\hline $\begin{array}{l}\text { Irregular leader exit } t_{t-1} * \\
\text { ln GDP per capita } t-1\end{array}$ & $\begin{array}{l}.01 \\
(.01)\end{array}$ & $\begin{array}{l}-.02 \\
(.03)\end{array}$ & $\begin{array}{l}-.01 \\
(.05)\end{array}$ & $\begin{array}{l}-.10 \\
(.07)\end{array}$ & $\begin{array}{l}-.07 \\
(.10)\end{array}$ & $\begin{array}{l}.04 * * \\
(.02)\end{array}$ & $\begin{array}{l}.02 \\
(.04)\end{array}$ & $\begin{array}{l}-.05 \\
(.06)\end{array}$ & $\begin{array}{l}-.10 \\
(.10)\end{array}$ & $\begin{array}{l}-.09 \\
(.12)\end{array}$ \\
\hline $\begin{array}{l}\text { Death from natural causes }{ }_{t-1} * \\
\text { ln GDP per capita }{ }_{t-1}\end{array}$ & $\begin{array}{l}.00 \\
(.01)\end{array}$ & $\begin{array}{l}-.00 \\
(.02)\end{array}$ & $\begin{array}{l}-.01 \\
(.04)\end{array}$ & $\begin{array}{l}-.09 \\
(.07)\end{array}$ & $\begin{array}{l}-.01 \\
(.13)\end{array}$ & $\begin{array}{l}.01 \\
(.02)\end{array}$ & $\begin{array}{l}-.02 \\
(.03)\end{array}$ & $\begin{array}{l}-.05 \\
(.05)\end{array}$ & $\begin{array}{l}-.07 \\
(.11)\end{array}$ & $\begin{array}{l}.09 \\
(.16)\end{array}$ \\
\hline $\begin{array}{l}\text { Deposed by foreign force } t_{t-1} * \\
\text { ln GDP per capita } t-1\end{array}$ & $\begin{array}{l}.02 \\
(.01)\end{array}$ & $\begin{array}{l}.01 \\
(.07)\end{array}$ & $\begin{array}{l}-.16 * * \\
(.08)\end{array}$ & $\begin{array}{l}-.08 \\
(.15)\end{array}$ & $\begin{array}{l}-.11 \\
(.11)\end{array}$ & $\begin{array}{l}.06 \\
(.06)\end{array}$ & $\begin{array}{l}.07 \\
(.10)\end{array}$ & $\begin{array}{l}-.12 \\
(.08)\end{array}$ & $\begin{array}{l}.05 \\
(.15)\end{array}$ & $\begin{array}{l}.22 \\
(.16)\end{array}$ \\
\hline $\begin{array}{l}\text { Leader retired }{ }_{t-1} * \\
\text { ln GDP per Capita } t_{-1}\end{array}$ & $\begin{array}{l}-.05 \\
(.06)\end{array}$ & $\begin{array}{l}-.00 \\
(.05)\end{array}$ & $\begin{array}{l}-.04 \\
(.08)\end{array}$ & $\begin{array}{l}-.23^{* * * *} \\
(.08)\end{array}$ & $\begin{array}{l}.02 \\
(.19)\end{array}$ & $\begin{array}{l}.03 * \\
(.01)\end{array}$ & $\begin{array}{l}.04 \\
(.04)\end{array}$ & $\begin{array}{l}-.09 \\
(.22)\end{array}$ & $\begin{array}{l}-.17 \\
(.18)\end{array}$ & $\begin{array}{l}-.31^{*} \\
(.17)\end{array}$ \\
\hline \multicolumn{11}{|l|}{$\begin{array}{l}\text { Cumulative effect of } \\
\text { income if leader }\end{array}$} \\
\hline -exited regular & $.29 * *$ & $.17 *$ & $.24 * * *$ & $.28 * *$ & $.35 * * *$ & $.05^{* *}$ & $.17 * * *$ & $.32 * * *$ & $.30 * *$ & $.36 * *$ \\
\hline -exited irregular & .11 & .04 & .09 & .05 & .14 & $.04 *$ & .06 & .11 & .08 & .10 \\
\hline -died of natural causes & .03 & .08 & $.11 *$ & .06 & .21 & .01 & .02 & $.10^{*}$ & .10 & .29 \\
\hline -was deposed & .16 & .09 & -.09 & .08 & .09 & .06 & .11 & .03 & .22 & $.41 *$ \\
\hline -retired due to health & -.55 & .07 & .06 & -.12 & $.25^{*}$ & .02 & .07 & .07 & .01 & -.11 \\
\hline Fisher $p$ level & {$[.00]$} & {$[.00]$} & {$[.00]$} & {$[.00]$} & {$[.00]$} & {$[.00]$} & {$[.00]$} & {$[.00]$} & {$[.05]$} & {$[.00]$} \\
\hline Observations & 6,370 & 1,205 & 586 & 384 & 276 & 6,161 & 1,160 & 569 & 373 & 271 \\
\hline Countries & 134 & 132 & 118 & 118 & 112 & 136 & 133 & 121 & 121 & 115 \\
\hline R-squared & .8712 & .6202 & .6027 & .6563 & .7428 & .1040 & .2761 & .4783 & .5738 & .7112 \\
\hline
\end{tabular}

Sources: see Table A18.

Note: All estimations by OLS with country and year fixed effects. Robust standard errors, clustered by country, in parentheses; * $\mathrm{p}<.10, * * \mathrm{p}<.05, * * * \mathrm{p}<.01$. "Fisher $\mathrm{p}$ level" is probability level at which one can reject H0: residuals are I(1), from Fisher test of residuals. "BMR": Boix-Miller-Rosato dichotomous measure. Too few cases of leader suicide to estimate effects. If more than one leader turnover during the panel interval, type of turnover refers to last one. Data adjusted so leader turnover not coded 1 if Polity 2 increased during panel period but there was no net increase after the leader exit. 


\section{Figure A3.A Estimated frequency of popular mobilizations around turnover of the top leader, non-democracies, 1920-2000}
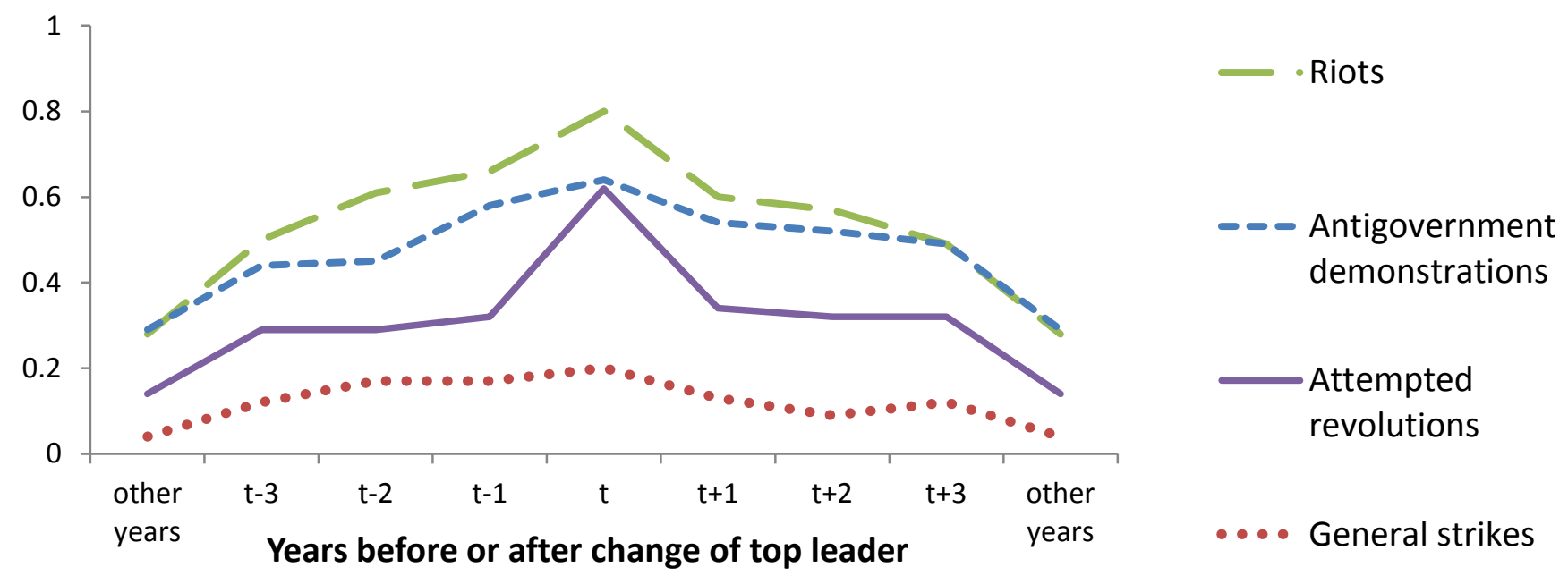

Source: Banks (2007), Archigos.

Note: From regressions controlling for country and year fixed effects . Antigovernment demonstration: "Any peaceful public gathering of at least 100 people for the primary purpose of displaying or voicing their opposition to government policies or authority, excluding demonstrations of a distinctly anti-foreign nature." General strike: "Any strike of 1,000 or more industrial or service workers that involves more than one employer and that is aimed at national government policies or authority."Attempted revolution: "Any illegal or forced change in the top government elite, any attempt at such a change, or any successful or unsuccessful armed rebellion whose aim is independence from the central government." Riot: "Any violent demonstration or clash of more than 100 citizens involving the use of physical force."

\section{Figure A3.B: Estimated frequency of antigovernment demonstrations around different types of leader turnover, nondemocracies 1920-2000}

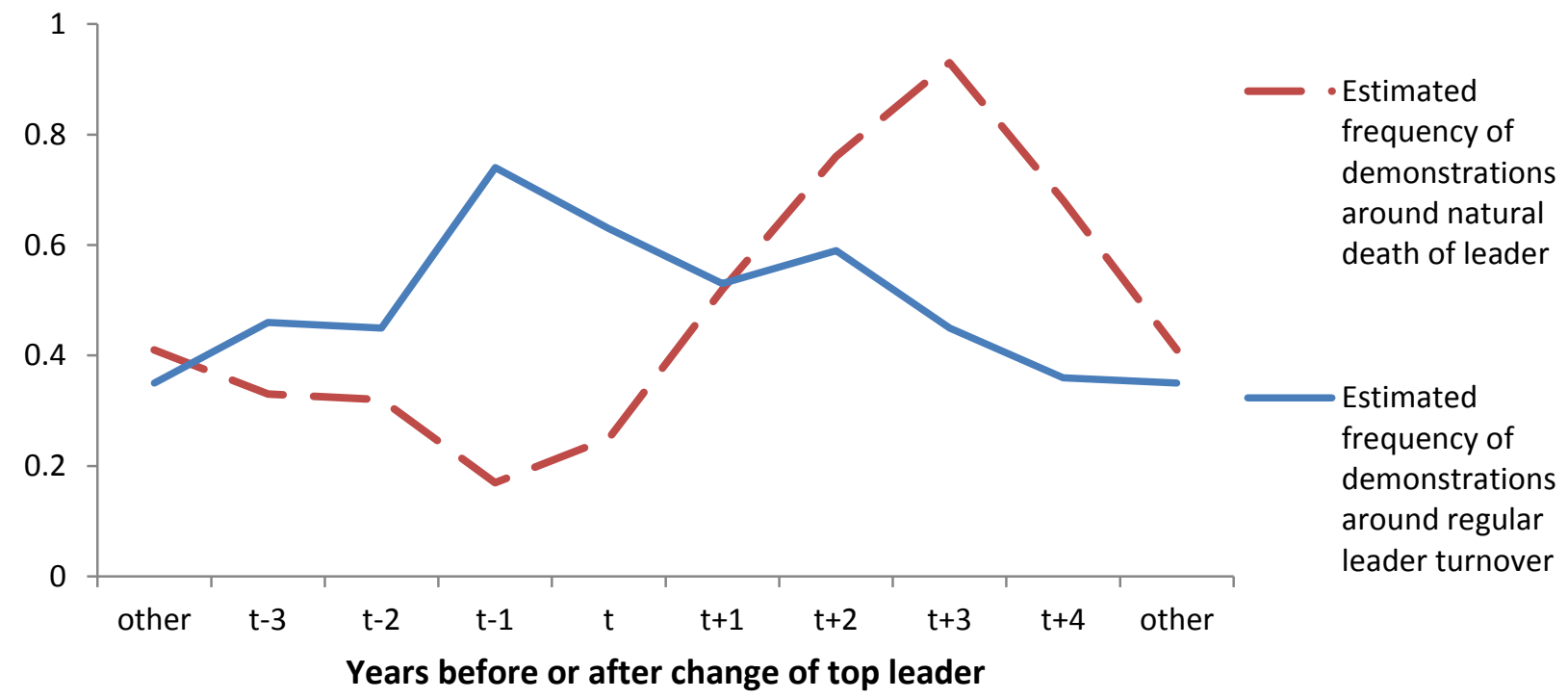

Source: Banks (2007), Archigos.

Note: From regressions controlling for country and year fixed effects . Antigovernment demonstration: "Any peaceful public gathering of at least 100 people for the primary purpose of displaying or voicing their opposition to government policies or authority, excluding demonstrations of a distinctly anti-foreign nature." 
The following graphs present marginal (short run) effects from estimation of an OLS regression of the country's Polity 2 score on its lagged Polity2 score and all elements and interactions of: the leader's total term, a set of dummies for the leader's current year in office, Ln GDP per capita in the previous year. The regression is run on non-democracies (Polity2 in previous year < 6) and includes full sets of country and year fixed effects; standard errors are robust and clustered by country. Since the many interactions are cumbersome to list, I summarize the results graphically.

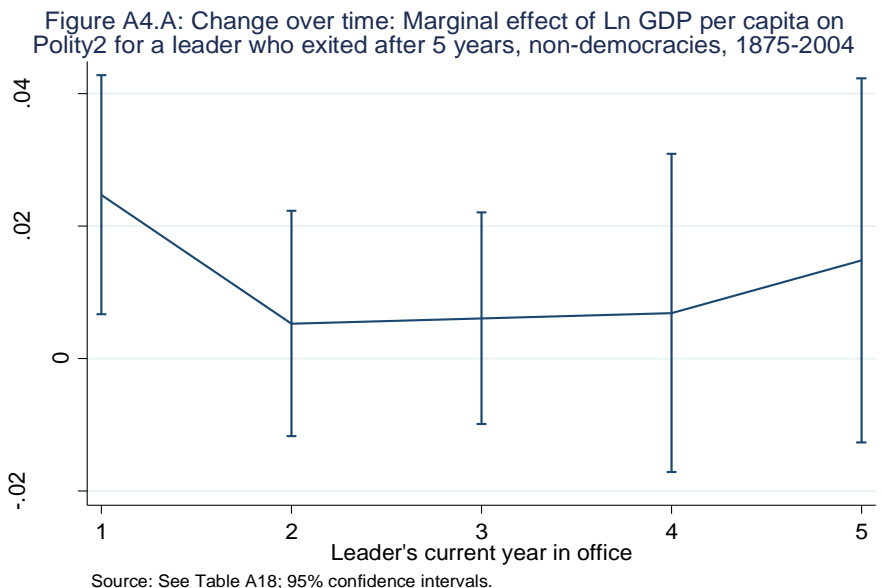

Figure A4B: Change over time: Marginal effect of Ln GDP per capita on Polity2 for a leader who exited after 8 years, non-democracies, 1875-2004

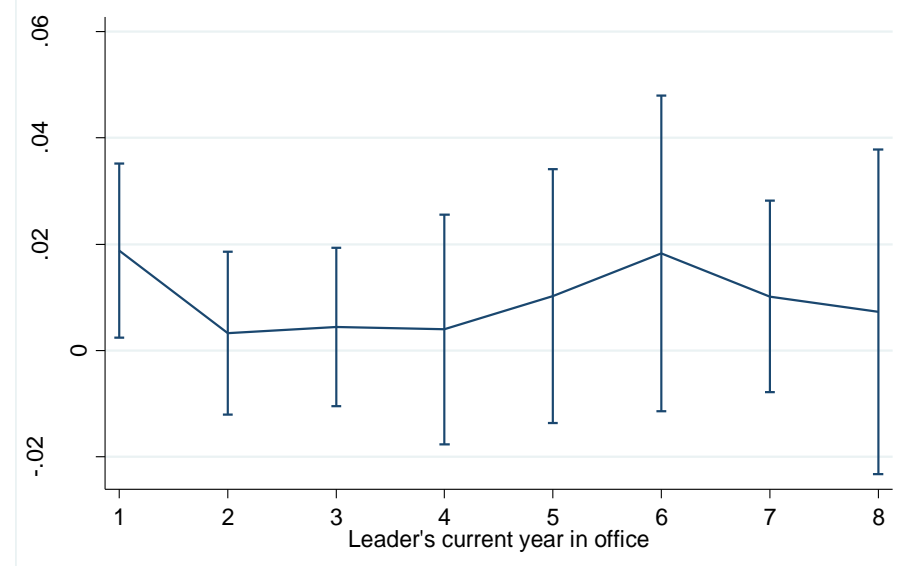

Source: See Table A18; 95\% confidence intervals.

Figure A4.C: Change over time: Marginal effect of Ln GDP per capita on Polity2 for a leader who exited after 15 years, non-democracies, 1875-2004

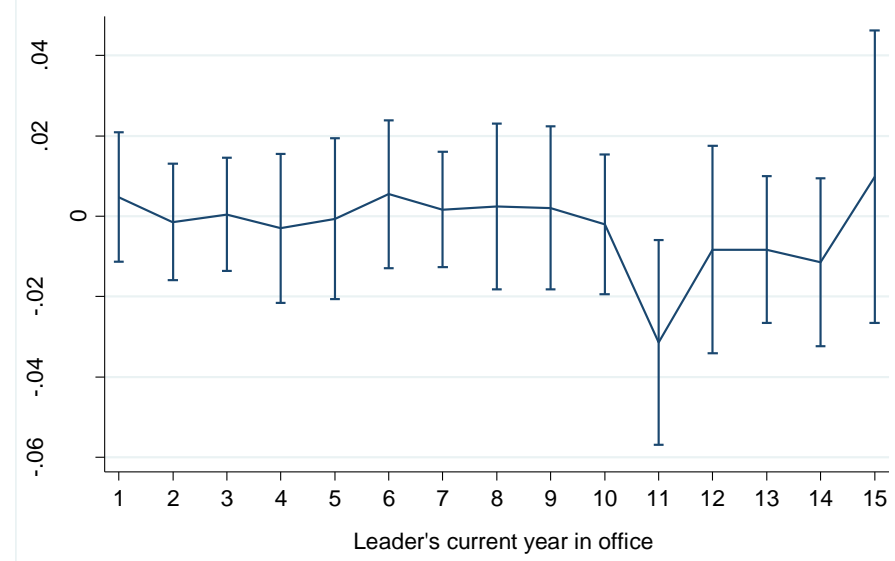

Source: See Table A18; 95\% confidence intervals. 
The goal of Table A16 is to test whether certain fixed characteristics of leaders and regimes, on which selection might operate, do in fact catalyze the effect of income on liberalization. Column 1 shows that leaders who have graduated from college tend to liberalize more when in countries with relatively high income. Column 2 shows that when the country's current income is high, those leaders who grew up at a time when the country was relatively developed tend to liberalize much more than those who grew up when it was still poor. This is consistent with the argument that those who came of age in more modern periods were socialized into values more favorable towards democracy and are therefore more likely to reform in response to the pressures for liberalization generated by development. Column 3 shows that military regimes tend to democratize more than other subtypes of nondemocracy, and that the estimated effect is higher in more developed countries. Thus, these characteristics are associated with greater liberalization in more developed countries.

\section{Table A16: Selection effects}

\begin{tabular}{|c|c|c|c|c|c|c|}
\hline \multirow[t]{2}{*}{ Dependent variable: } & \multicolumn{6}{|c|}{ Polity2, Polity $2_{t-1}<6$, annual data } \\
\hline & (1) & & (2) & & (3) & \\
\hline Polity2 $\mathrm{t}-1$ & $\begin{array}{l}.91 * * * \\
.01)\end{array}$ & & $\begin{array}{l}.90 * * * \\
(.02)\end{array}$ & & $\begin{array}{l}.90 * * * \\
(.02)\end{array}$ & \\
\hline Ln GDP per capita $t-1$ & $\begin{array}{l}-.006 \\
(.006)\end{array}$ & & $\begin{array}{l}-.001 \\
(.006)\end{array}$ & & $\begin{array}{l}-.001 \\
(.007)\end{array}$ & \\
\hline Leader has college degree $t$ & $\begin{array}{l}-.06 * \\
(.03)\end{array}$ & & & & & \\
\hline Leader has college degree ${ }_{t} *$ Ln GDP per capita $t-1$ & $\begin{array}{l}.009^{*} \\
(.005)\end{array}$ & & & & & \\
\hline Ln GDP per capita when leader was 20 & & & $\begin{array}{l}-.08 * \\
(.04)\end{array}$ & & & \\
\hline $\begin{array}{l}\text { Ln GDP per capita when leader was } 20 * \\
\text { Ln GDP per capita t-1 }\end{array}$ & & & $\begin{array}{l}.012 * * \\
(.005)\end{array}$ & & & \\
\hline Military regime $\mathrm{t}-1$ & & & & & $\begin{array}{l}-.035 \\
(069)\end{array}$ & \\
\hline Military regime $_{\mathrm{t}-1} *$ Ln GDP per capita $\mathrm{t}-1$ & & & & & $\begin{array}{l}.009 \\
(.009)\end{array}$ & \\
\hline $\begin{array}{l}\text { Cumulative effect of leader's college degree } \\
\text { when income is: } \\
-\$ 1,000 \\
-\$ 5,000 \\
-\$ 10,000\end{array}$ & $\begin{array}{l}.02 \\
.18^{* *} \\
.25^{* *}\end{array}$ & $\begin{array}{l}(.05) \\
(.08) \\
(.12)\end{array}$ & & & & \\
\hline $\begin{array}{l}\text { Cumulative effect of prodemocratic values (proxied } \\
\text { Ln GDP p.c. when leader was } 20 \text { ), when current } \\
-\$ 1,000 \\
-\$ 5,000 \\
-\$ 10,000\end{array}$ & & & $\begin{array}{l}.06 \\
.27 * * \\
.35 * * *\end{array}$ & $\begin{array}{l}(.10) \\
(.11) \\
(.13)\end{array}$ & & \\
\hline $\begin{array}{l}\text { Cumulative effect of military regime, when income } \\
\quad-\$ 1,000 \\
-\$ 5,000 \\
-\$ 10,000\end{array}$ & & & & & $\begin{array}{l}.30 * * \\
.45 * * * \\
.52 * * *\end{array}$ & $\begin{array}{l}(.13) \\
(.14) \\
(.18)\end{array}$ \\
\hline $\begin{array}{l}\text { Fisher p level } \\
\text { Observations } \\
\text { Countries } \\
\text { R-squared }\end{array}$ & $\begin{array}{l}{[.00]} \\
6,266 \\
134 \\
.8686 \\
\end{array}$ & & $\begin{array}{l}{[.00]} \\
4,866 \\
119 \\
.8722 \\
\end{array}$ & & $\begin{array}{l}{[.00]} \\
4,295 \\
121 \\
.8488 \\
\end{array}$ & \\
\hline
\end{tabular}

Sources: see Table A18.

Note: All estimations by OLS with country and year fixed effects. Robust standard errors, clustered by country, in parentheses; $* \mathrm{p}<.10, * * \mathrm{p}<.05, * * * \mathrm{p}<.01$. "Fisher $\mathrm{p}$ level" is probability level at which one can reject H0: residuals are I(1), from Fisher test of residuals. Geddes et al. (2012) classification of military regimes used. 
Table 5 estimated the relationships between leaders' tenure in office and likelihood of taking various risky actions, using a conditional logit fixed effects model. This requires dropping all countries which do not contain variation over time in the dependent variable, which sometimes means excluding a large proportion of the data. Below, I present identical estimations using the linear probability model to show that results are not dependent on the exclusion of data.

\section{Table A17: Does activism decrease with leader tenure? Re-estimating with linear probability model}

\begin{tabular}{|c|c|c|c|c|}
\hline $\begin{array}{l}\text { Dependent variable: } \\
\text { Dummy for }\end{array}$ & $\begin{array}{l}\text { Polity2 } \\
\text { moved up }\end{array}$ & $\begin{array}{l}\text { Polity } 2 \\
\text { moved down }\end{array}$ & $\begin{array}{l}\text { Major } \\
\text { change to } \\
\text { constitution }\end{array}$ & $\begin{array}{l}\text { State initiated a } \\
\text { militarized } \\
\text { interstate dispute }\end{array}$ \\
\hline Cases: & Polity $2_{t-1}<10$ & Polity $2_{t-1}>-10$ & All & All \\
\hline & $(1)$ & (2) & (3) & (4) \\
\hline Leader's years in office & $\begin{array}{l}-.004 * * * \\
(.001)\end{array}$ & $\begin{array}{l}-.003 * * * \\
(.000)\end{array}$ & $\begin{array}{l}-.006 * * * \\
(.001)\end{array}$ & $\begin{array}{l}-.003^{*} \\
(.001)\end{array}$ \\
\hline $\begin{array}{l}\text { Leader's years in office } * \\
\text { democracy dummy t-1 }\end{array}$ & $\begin{array}{l}.008 * * * \\
(.002)\end{array}$ & $\begin{array}{l}.002 * * \\
(.001)\end{array}$ & $\begin{array}{l}.004 * * * \\
(.001)\end{array}$ & $\begin{array}{l}.005 \\
(.003)\end{array}$ \\
\hline $\begin{array}{l}\text { Democracy dummy } \\
\quad(\text { Polity } 2 \geq 6)_{t-1}\end{array}$ & $\begin{array}{l}-.16^{* * * *} \\
(.02)\end{array}$ & $\begin{array}{l}.013 \\
(.014)\end{array}$ & $\begin{array}{l}-.082 * * * \\
(.014)\end{array}$ & $\begin{array}{l}-.088 * * \\
(.038)\end{array}$ \\
\hline Leader's age & $\begin{array}{l}-.000 \\
(.000)\end{array}$ & $\begin{array}{l}-.000 \\
(.000)\end{array}$ & $\begin{array}{l}.000 \\
(.000)\end{array}$ & $\begin{array}{l}.000 \\
(.001)\end{array}$ \\
\hline Ln GDP per capita $t-1$ & $\begin{array}{l}-.068 * * \\
(.026)\end{array}$ & $\begin{array}{l}-.026 * * \\
(.011)\end{array}$ & $\begin{array}{l}-.048 * * * \\
(.012)\end{array}$ & $\begin{array}{l}-.063 \\
(.038)\end{array}$ \\
\hline Growth rate ${ }_{t-1}$ & $\begin{array}{l}-.002 * * * \\
(.001)\end{array}$ & $\begin{array}{l}-.002 * * * \\
(.001)\end{array}$ & $\begin{array}{l}-.003 * * * \\
(.001)\end{array}$ & $\begin{array}{l}-.003 * * \\
(.001)\end{array}$ \\
\hline $\begin{array}{l}\text { Ln antigovernment } \\
\text { demonstrations } t-1\end{array}$ & $\begin{array}{l}.05 * * * \\
(.01)\end{array}$ & $\begin{array}{l}.005 \\
(.006)\end{array}$ & $\begin{array}{l}.036 * * * \\
(.009)\end{array}$ & $\begin{array}{l}.002 \\
(.013)\end{array}$ \\
\hline $\begin{array}{l}\text { Country's past rate of } \\
\text { initiating MIDs }\end{array}$ & & & & $\begin{array}{l}.088 \\
(.171)\end{array}$ \\
\hline State's military capability t-1 & & & & $\begin{array}{l}-.26 \\
(1.92)\end{array}$ \\
\hline Trade as share of GDP $t-1$ & & & & $\begin{array}{l}.033 \\
(.051)\end{array}$ \\
\hline $\begin{array}{l}\text { Head of state a military } \\
\text { officer }\end{array}$ & & & & $\begin{array}{l}.044 \\
(.034)\end{array}$ \\
\hline Fisher $\mathrm{p}$ level & {$[.00]$} & {$[.00]$} & {$[.00]$} & {$[.00]$} \\
\hline Observations & 6,098 & 7,357 & 7,559 & 5,400 \\
\hline Countries & 141 & 150 & 152 & 148 \\
\hline R squared & .1252 & .0822 & .1088 & .2651 \\
\hline
\end{tabular}

Sources: Table A18.

Note: All estimations by OLS, with full sets of country and year dummies. Annual data. Standard errors in parentheses; * p < $.10, * * \mathrm{p}<.05, * * * \mathrm{p}<.01 .{ }^{a}$ years in which state does not initiate a MID but continues one it previously initiated are excluded. Cases where lagged Polity2 score equals $10(-10)$ excluded in column 1 (2) to adjust for fact that countries cannot move beyond the limit of the scale. 
Table A18: Data sources

\begin{tabular}{|c|c|c|}
\hline Variable & Notes & Source \\
\hline $\begin{array}{l}\text { Democracy: close to } \\
\text { continuous measure }\end{array}$ & Polity2, rescaled to take values from 0 to 1 . & $\begin{array}{l}\text { Polity IV Dataset, Version 2009, } \\
\text { http://www.systemicpeace.org/inscr/inscr.htm }\end{array}$ \\
\hline $\begin{array}{l}\text { Democracy: binary } \\
\text { measure }\end{array}$ & Dummy: 1 = democracy; 0 = non-democracy. & $\begin{array}{l}\text { Constructed by Boix, Miller and Rosato (2013), } \\
\text { for } 1800-2007 \text {. }\end{array}$ \\
\hline $\begin{array}{l}\text { GDP, GDP per } \\
\text { capita, GDP per } \\
\text { capita growth }\end{array}$ & In 1990 international Geary-Khamis dollars. & $\begin{array}{l}\text { Maddison (2010), downloaded from } \\
\text { http://www.ggdc.net/MADDISON/oriindex.htm }\end{array}$ \\
\hline Trade & Trade between dyads of countries, in 1990 dollars. & $\begin{array}{l}\text { Dataset for Russett, Oneal, and Berbaum (2003), } \\
\text { downloaded from Bruce Russett's website at: } \\
\text { http://pantheon.yale.edu/ brusset/. }\end{array}$ \\
\hline $\begin{array}{l}\text { Domestic } \\
\text { democratic capital, } \\
\text { foreign democratic } \\
\text { capital }\end{array}$ & Definitions in Persson and Tabellini (2009) & $\begin{array}{l}\text { Dataset for Persson and Tabellini (2009), } \\
\text { downloaded from Guido Tabellini's website at } \\
\text { http://didattica.unibocconi.it/mypage/index.php?I } \\
\text { dUte=48805\&idr=7569\&lingua=ita. }\end{array}$ \\
\hline Average schooling & $\begin{array}{l}\text { Average years of schooling in population aged } 15 \\
\text { and over }\end{array}$ & $\begin{array}{l}\text { Morrisson and Murtin (2009), downloaded } \\
\text { www.pse.ens.fr/data/index.html. }\end{array}$ \\
\hline $\begin{array}{l}\text { Leader turnover, } \\
\text { timing and type; } \\
\text { leaders' ages, other } \\
\text { characteristics }\end{array}$ & & $\begin{array}{l}\text { Archigos, downloaded from Henk Goemans' } \\
\text { website } \\
\text { http://www.rochester.edu/college/faculty/hgoema } \\
\text { ns/data.htm. }\end{array}$ \\
\hline $\begin{array}{l}\text { War, civil war, } \\
\text { initiators of war, } \\
\text { militarized interstate } \\
\text { disputes, military } \\
\text { capacity }\end{array}$ & & $\begin{array}{l}\text { Correlates of War intrastate and interstate wars } \\
\text { datasets, v.4.0, Militarized interstate disuptes } \\
\text { v.3.10, National material capabilities, v.4.0, } \\
\text { downloaded from } \\
\text { http://www.correlatesofwar.org/datasets.htm }\end{array}$ \\
\hline Military regime & Head of State coded as "military" in Banks dataset. & $\begin{array}{l}\text { Arthur Banks' "Cross- National Time-Series } \\
\text { Data Archive". }\end{array}$ \\
\hline Monarchy & Head of State coded as "monarch" in Banks dataset. & Banks (see above) \\
\hline $\begin{array}{l}\text { Oil and gas income } \\
\text { per capita }\end{array}$ & & $\begin{array}{l}\text { Michael L. Ross, 2011-04, "Replication data for: } \\
\text { Oil and Gas Production and Value, 1932-2009", } \\
\text { http://thedata.harvard.edu/dvn/dv/mlross }\end{array}$ \\
\hline $\begin{array}{l}\text { Military, personalist, } \\
\text { one-party, } \\
\text { monarchical } \\
\text { autocracies }\end{array}$ & & $\begin{array}{l}\text { Geddes, Barbara, Joseph Wright and Erica } \\
\text { Frantz. 2012. “Authoritarian Regimes: A New } \\
\text { Data Set."' Manuscript. Data at } \\
\text { http://dictators.la.psu.edu/ }\end{array}$ \\
\hline $\begin{array}{l}\text { Antigovernment } \\
\text { protests }\end{array}$ & $\begin{array}{l}\text { Any peaceful public gathering of at least } 100 \text { people } \\
\text { for the primary purpose of displaying or voicing } \\
\text { their opposition to government policies or authority, } \\
\text { excluding demonstrations of a distinctly anti-foreign } \\
\text { nature. }\end{array}$ & Banks (see above) \\
\hline Riots & $\begin{array}{l}\text { Any violent demonstration or clash of more than } 100 \\
\text { citizens involving the use of physical force. }\end{array}$ & Banks (see above) \\
\hline General strikes & $\begin{array}{l}\text { Any strike of } 1,000 \text { or more industrial or service } \\
\text { workers that involves more than one employer and } \\
\text { that is aimed at national government policies or } \\
\text { authority. }\end{array}$ & Banks (see above) \\
\hline $\begin{array}{l}\text { Attempted } \\
\text { revolutions }\end{array}$ & $\begin{array}{l}\text { Any illegal or forced change in the top government } \\
\text { elite, any attempt at such a change, or any successful } \\
\text { or unsuccessful armed rebellion whose aim is } \\
\text { independence from the central government. }\end{array}$ & Banks (see above) \\
\hline Assassinations & $\begin{array}{l}\text { Any politically motivated murder or attempted } \\
\text { murder of a high government official or politician. }\end{array}$ & Banks (see above) \\
\hline Guerrilla warfare & $\begin{array}{l}\text { Any armed activity, sabotage, or bombings carried } \\
\text { on by independent bands of citizens or irregular } \\
\text { forces and aimed at the overthrow of the } \\
\text { present regime. }\end{array}$ & Banks (see above) \\
\hline $\begin{array}{l}\text { Major government } \\
\text { crisis }\end{array}$ & $\begin{array}{l}\text { Any rapidly developing situation that threatens to } \\
\text { bring the downfall of the present regime - excluding } \\
\text { situations of revolt aimed at such overthrow. }\end{array}$ & Banks (see above) \\
\hline $\begin{array}{l}\text { Major constitutional } \\
\text { changes }\end{array}$ & $\begin{array}{l}\text { The number of basic alterations in a state's } \\
\text { constitutional structure, the extreme case being the }\end{array}$ & Banks (see above) \\
\hline
\end{tabular}




\begin{tabular}{|l|l|l|}
\hline & $\begin{array}{l}\text { adoption of a new constitution that significantly } \\
\text { alters the prerogatives of the various branches of } \\
\text { government. Examples of the latter might be the } \\
\text { substitution of presidential for parliamentary } \\
\text { government or the replacement of monarchical by } \\
\text { republican rule. Constitutional amendments which } \\
\text { do not have significant impact on the political } \\
\text { system are not counted. }\end{array}$ & \\
\hline Elected parliament & Legislative selection = "elective" in Banks dataset. & Banks (see above) \\
\hline Elected executive & Executive elected directly or by elected legislature & Banks (see above) \\
\hline Non-regime parties & $\begin{array}{l}\text { "defacto 2": existence of parties outside of regime } \\
\text { front }\end{array}$ & $\begin{array}{l}\text { Democracy and Dictatorship Revisited dataset, } \\
\text { José Cheibub, Jennifer Gandhi, James Vreeland } \\
\text { (Georgetown University), September 2009 (v.1) }\end{array}$ \\
\hline Press freedom index & Freedom House & Downloaded from www.freedomhouse.org \\
\hline Education of leaders & Besley and Reynal-Querol (2011) & Provided by Marta Reynal-Querol. \\
\hline $\begin{array}{l}\text { Mass resistance } \\
\text { campaigns }\end{array}$ & & Chenoweth and Stephan (2011) \\
\hline
\end{tabular}

